\title{
ТЕНДЕНЦИИ РАЗВИТИЯ НАУКИ И ОБРАЗОВАНИЯ
}

Научный журнал

Август 2018 г.

HOMEP 41

ЧАСТЬ 2

\section{JOURNAL_RU}

Самара 2018 
УДК 001.1

ББК 60

T34

Тенденции развития науки и образования. «Тенденции развития науки и образования» Август 2018 г. Часть 2 Изд. НИЦ «ЛЖурнал», 2018. - 84c.

SPLN 001-000001-0329-LJ

DOI 10.18411/lj-08-2018-2

IDSP 000001:lj-08-2018-2

В выпуске журнала собраны материалы из различных областей научных знаний.

Журнал предназначен для научных работников, преподавателей, аспирантов и студентов.

Все материалы, размещенные в журнале, опубликованы в авторском варианте. Редакция не вносила коррективы в научные статьи. Ответственность за информацию, размещенную в материалах на всеобщее обозрение, несут их авторы.

Информация об опубликованных статьях будет передана в систему ELIBRARY

Электронная версия журнала доступна на сайте научноиздательского центра «Л-Журнал». Сайт центра: ljournal.ru

УДК 001.1

ББК 60 


\section{Содержание}

РАЗДЕЛ ІІ. ПСИХОЛОГИЯ .5

Власова Ю.А., Калачикова Е.А. Взгляд на инфантильность как характеристику личности в психологических концепциях XX века

Гайкина М.Ю., Коточигова М.В. Мотивы противоправного поведения несовершеннолетних детей, совершающих мелкое хищение.

Зак А.3. Особенности изменения сформированности когнитивных метапредметных компетенций у детей 10 - 11 лет .....

Просекова Е.Н. Особенности развития самосознания в ранней юности .... 19

РАЗДЕЛ ІІІ. СОЦИОЛОГИЯ 23

Плеханова О.В. Средства формирования имиджа местного самоуправления 23

Попова Е.В., Брюхнова А.В. Феминизм в рекламе 26

РАЗДЕЛ IV. МЕНЕДЖМЕНТ 30

Амурская О.И., Муравьева А.В. Значимость бренда в сфере образовательных услуг

Финашина Т.В. Особенности маркетинговых мероприятий, направленных на улучшение имиджа учреждения культуры

РАЗДЕЛ У. ЭКОНОМИКА

Батаев А.В. Анализ мирового рынка добычи нефти

Граница Ю.В. Аудиторский контроль соблюдения требований федеральных государственных стандартов образовательными организациями

Граница Ю.В. Содержание научно-исследовательской работы обучающихся, освоивших образовательный блок дисциплин «Бухгалтерский учет» 40

Деревянко П.С. Банки будущего и появление эко среды. 46

Каранда А.В. Сельское хозяйство Республики Крым: проблемы и перспективы. .49

Любова О.В. Применение принципа равновесия при сбалансированном развитии территории 
РАЗДЕЛ VІ. ЮРИСПРУДЕНЦИЯ

Лавёрычева С.А. Труд осужденных в следственном изоляторе: право или обязанность ....

Молчанова Е.Р. Чартер и коносамент: проформы, виды, особенности 61

Токарева К.Г. О некоторых аспектах качества сферы бытового обслуживания 62

Токарева К.Г., Сейидова Е.P. Ответственность сторон за неисполнение или ненадлежащее исполнение договора поставки .66

РАЗДЕЛ VIІ. ФИЛОЛОГИЯ .70

Буров А.А.. Куимов Р.Н. К вопросу о структурации идиостиля автора прозаического текста .70

Горшунов Ю.В. Ре-интерпретация структуры слова в популярных английских детских шутках и загадках .74

Горшунов Ю.В. Ономатопея в популярных детских шутках, анекдотах и загадках..... 75 Додукова Е.С. Роль метафоры в социальной рекламе, посвященной пропаганде чтения .77

Куксова Е.Л. Роль и место французского языка во франкоязычной Африке 80 


\section{РАЗДЕЛ ІІ. ПСИХОЛОГИЯ}

\section{Власова Ю.А., Калачикова Е.А. \\ Взгляд на инфантильность как характеристику личности в психологических концепциях XX века}

Наџиональный исследовательский Томский государственньй университет (Россия, Томск)

doi: $10.18411 / \mathrm{j}-08-2018-28$

idsp: 000001:lj-08-2018-28

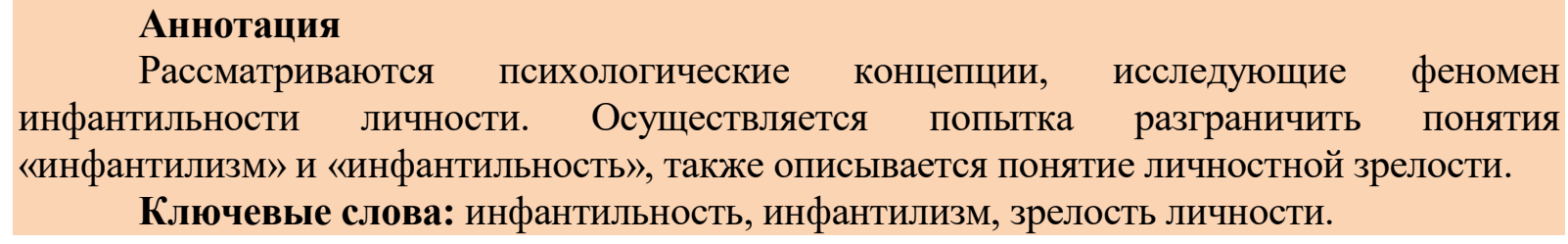

\section{Abstract}

The psychological concepts exploring the phenomenon of infantile personality are considered. An attempt is made to distinguish the concepts of "infantilism" and "infantilism of personality" and the concept of personal maturity is also described.

Keywords: infantilism, infantilism of personality, personal maturity.

Слово «инфантильность» зачастую используют для описания ряда особенностей современной молодёжи. Психологи характеризуют инфантильность как уход от ответственности, а также неспособность самостоятельного выбора. Сегодня инфантильность становится одной из важнейших проблем, поскольку в настоящее время наблюдается рост количества социально незрелых молодых людей, которые не могут принимать на себя ответственность в решении важных социальных, политических, экономических вопросов [1], [2], [4].

Задача данной статьи - рассмотреть точки зрения известных исследователей на данный феномен.

В академической науке понятие «инфантильность» не используется, несмотря на то, что инфантильность представляет собой одно из свойств личности. В психиатрии и в психологии имеет активное хождение термин «инфантилизм», введённый Эрнестом Ласег [4]. В 1864 году он понимал под инфантилизмом сохранение у взрослых психических и физических признаков, свойственных детям. Психический инфантилизм - личностная незрелость с преимущественным отставанием в развитии эмоционально-волевой сферы и сохранением детских качеств личности.

Психологический инфантилизм [1] характеризуется как черты в поведении, мышлении, эмоциональных реакциях не соответствующие возрастным требованиям. В отличие от психического инфантилизма, в данном случе человек имеет вполне здоровую психику и может изменить свое поведение, при появлении соответствующих мотивов, осознании, рефлексии.

Такое явление, как «социальный инфантилизм» [2] представляет из себя моральнонравственную незрелость при сохранном интеллекте и отсутствии соматической патологии, что приводит к недостаточно полноценному функционированию в обществе и говорит о нарушении механизма социализации, непринятии общественных норм.

В психиатрии [4] принято выделять четыре вида инфантилизма: гармонический (простой), дисгармонический, церебро-органического генеза и психогенный. Все 
перечисленные варианты инфантилизма относятся к такому виду дизонтогенеза, как задержка психического развития.

Изучение инфантильности ведется несколько десятилетий. Проблемой данного феномена интересовались многие ученые, рассматривая его в рамках своих концепций. Также с развитием психиатрии это явление стало описываться в качестве источника возникновения психопатий.

Инфантильность рассматривалась 3. Фрейдом [10] как фиксация на одной из стадий развития. Он говорил о том, что такие вредные привычки как грызть ногти, курить или переедать могут быть связаны с частичной фиксацией на оральной стадии и обусловлены «неполнотой» психической зрелости.

Типичным проявлением инфантильности, по мнению Фрейда, является защитный механизм регрессии - возвращение на более ранний уровень развития или к способу выражения, который более прост и более свойственен детям, тревожность ослабляется также «детскими» способами [11].

К. Юнг [14], описывая истоки внутриличностных конфликтов, перечисляет в качестве причин неврозов и неудовлетворенности человека собой такие инфантильные на наш взгляд характеристики, как эгоизм, пассивность и др. Кроме того, типичной инфантильной чертой, как считает Юнг, является зависимость - «особая внутренняя привязанность, которая может чем-нибудь заменяться» [14, С.54]. Именно зависимость подавляет развитие личности, «потому что ничто так не препятствует развитию, как застывание в бессознательном, можно даже сказать, в психически эмбриональном состоянии».

Особенности воспитания, как возможная причина «взрослых» проблем широко исследуется в работах А. Адлера [11]. Одной из преград для личностного роста А. Адлер называет избалованность. Избалованные дети, по мнению А. Адлера, имеют трудности в развитии «чувства социального интереса и кооперации». Такие дети не уверены в своих силах, потому что часто все делали за них.

Инфантильность рассматривается также как возможная причина внутриличностного конфликта у Карен Хорни [12]. К. Хорни описывает понятие «базального конфликта» и особенности невротической личности, «заложенные в нашей культуре, которые невротик отчаянно пытается примирить: склонность к агрессивности и тенденцию уступать; чрезмерные притязания и страх никогда ничего не получить; стремление к самовозвеличиванию и ощущение личной беспомощности» [11, С. 56]. Наиболее четко инфантильные черты прослеживаются в тенденции «движения к людям» - а именно в таком виде как «уступчивый тип»: «данный тип демонстрирует заметно выраженную потребность в любви и одобрении и особую потребность в партнере, который должен взять на себя ответственность за все доброе и злое... Будучи предоставленным самому себе, он чувствует себя потерянным, подобно лодке, потерявшей свой якорь. Эта беспомощность отчасти соответствует действительности» $[11$, C.56]. Кроме того, характерной чертой для этого типа личности является зависимость.

Э. Эриксон [13] и вовсе считает, что инфантильные черты могут быть абсолютно у любого взрослого человека. Он говорит о том, что каждое поколение привносит в социальные институты пережитки инфантильных потребностей и юношеского пыла. Также как и 3. Фрейд, Э. Эриксон полагает, что проблемы, возникающие на определенной стадии развития, могут привести к фиксации и регрессии.

Э. Берн [3] утверждает, что «каждый таит в себе маленького мальчика или девочку». Ведь «детское Я отвечает за творчество, оригинальность, получение приятных впечатлений, детское Я выступает на сцену, когда человек не чувствует достаточно сил для самостоятельного решения проблем». Так как для оптимального функционирования личности необходима гармоничная представленность всех трех состояний, то Э. Берн считает, что понятия «незрелая личность» не существует, - «есть люди, в которых Ребенок совершенно некстати и неумело берет на себя управление всей личностью, а у 
так называемых «зрелых» людей контроль за поведением почти все время осуществляет Взрослый» [там же].

В гуманистических теориях личности акцент делается не на описании инфантильности, а на рассмотрении противоположного явления - зрелости. Это логично отражается сквозь призму основной идеи о том, что психологии необходимо не классифицировать человеческие слабости и патологии, а описать психологически здорового человека. Широко используется понятие самоактуализирующаяся личность, которая обладает такими чертами зрелости как автономия и ответственность. Остановимся более подробно на гуманистических теориях, где глубоко рассматривается не только само понятие зрелой, актуализирующейся личности, но и присущие ей черты.

А. Маслоу [5], создавая свои представления о том, какой должна быть личность, исходил из исследования только здоровых и творческих людей.

Он говорил о том, что, если личность созревает в благоприятном окружении, творческие силы безусловно будут проявляться ярче. «Когда люди несчастливы или невротичны, то это оттого, что окружение сделало их таковыми, будучи невежественным или социально патологичным, или же потому, что их мышление искажено» [11, С. 163]. Также он сделал предположение, что у многих людей есть страх стать самоактуализировавшимися и многие вынужденно скрывают от себя такую возможность. Можно предположить, что этот страх самораскрытия, сдерживание собственной самоактуализации, можно рассмотреть как проявление незрелости и инфантильности личности.

В теории личности К. Роджерса [8] есть два конструкта, имеющих основополагающее значение для данной теории. Это «организм» и «Я». Нам будет интересен термин «Я». Это дифференцируемая часть феноменального поля. «Я» или представление о себе означает «организованный, согласованный концептуальный гештальт, построенный из перцепций характеристик «я» или «меня» и перцепций отношений «я» или «меня» к другим людям и различным аспектам жизни [11, С. 174].

Здесь важными являются понятия конгруэнтности и неконгруэнтности между воспринимаемым «Я» и актуальным опытом переживаний организма. Когда сознательные переживания, которые образуют «Я», наиболее точно отражают переживания организма, о человеке говорят, что он адаптирован, зрел и полностью функционирует. Такой человек способен принять всю «палитру» организмических переживаний, не испытывая угрозы или тревоги, способен мыслить реалистически. Проявление неконгруэнтности между «Я» и организмом несет за собой угрозу и тревогу для личности. В этом случае прослеживается появление защитных механизмов, а также мышление становится довольно ригидным.

Проявление неконгруэнтности можно считать характерным признаком инфантильности.

По К. Роджерсу у организма есть одна основная и главная тенденция, которая представляет собой стремление к актуализации, силе и твердости. Эта актуализирующая тенденция очень избирательна. Можно сделать предположение, что незрелая, инфантильная личность не неспособна достигать завершенности, целостности, она растождествлена с собой и своим стремлением к актуализации.

В теории Г. Олпорта [7] важным для нас является понятие функциональной автономии. Принцип автономии утверждает, что любая активность или форма поведения может стать итогом или целью даже если сначала была предназначена для чего-либо другого. Так, любое поведение, несмотря на то, что могло возникнуть в связи с органическим или каким-либо другим напряжением, способно к самостоятельному существованию при отсутствии подкрепления. Настоящая формулировка выглядит следующим образом: «Принцип функциональной автономии рассматривает зрелые мотивы как разнообразные самоподдерживающие одновременно существующие системы, 
вырастающие из предшествующих систем, но функционально от них независимые» [11, C. 257].

Таким образом, концепция функциональной автономии говорит о том, что мотивы зрелой личности ни в коем случае не определяются прошлыми мотивами. Или причины, по которым человек ведет себя так, а не иначе никак не связаны с тем, какие причины изначально побудили его к такому поведению. Зрелая личность полностью свободна от прошлого, а имеющиеся связи с прошлым являются лишь историческими, но не как не детерминантными.

Согласно данному положению, можно сказать, что мотивы незрелой личности определены прошлым, и поведение такой личности не гибкое, не способное к самостоятельному существованию, оно зависимо от какого-либо подкрепления.

Г. Олпорт говорит о том, что не все взрослые способны управлять своим поведением на основе разумных и четких принципов. Однако то, насколько их черты отличны от детских и то, как умело они избегают бессознательной мотивации, представляет степень их зрелости и здоровья в том числе. Только при крайних нарушениях можно увидеть взрослого, который не знает, что делать и чье поведение ориентировано в детство, в прошлое, нежели на то, что происходит сейчас и что будет происходить в будущем.

Описание Г. Олпортом взрослых, не достигших полной зрелости очень похоже на описание инфантильной личности.

При сопоставлении критериев самоактуализирующейся личности по А. Маслоу, полноценно функционирующего человека по К. Роджерсу, зрелой личности по Г. Олпорту, очевидны совпадения и пересечения. Иллюстрируем в таблице.

\begin{tabular}{|c|c|c|}
\hline Абрахам Маслоу & Карл Роджерс & Гордон Олпорт \\
\hline «Самоактуализирующаяся личность» & $\begin{array}{c}\text { «Полноценно } \\
\text { функционирующий человек» }\end{array}$ & «Зрелая личность» \\
\hline $\begin{array}{c}\text { Непосредственность, простота и } \\
\text { естественность }\end{array}$ & Организмическое доверие & \\
\hline Креативность & Креативность & \\
\hline Свежесть восприятия & Открытость переживанию & \\
\hline \multirow[t]{2}{*}{ Автономия от культуры и окружения } & Эмпирическая свобода & \\
\hline & $\begin{array}{l}\text { Экзистенциальный образ } \\
\text { жизни } \\
\end{array}$ & $\begin{array}{c}\text { Цельная жизненная } \\
\text { философия }\end{array}$ \\
\hline Принятие себя, других, природы & & $\begin{array}{c}\text { Эмоциональная } \\
\text { неозабоченность и } \\
\text { самоприятие }\end{array}$ \\
\hline Философское чувство юмора & & $\begin{array}{c}\text { Способность к самопознанию } \\
\text { и чувство юмора }\end{array}$ \\
\hline $\begin{array}{c}\text { Более эффективное восприятие } \\
\text { реальности }\end{array}$ & & $\begin{array}{c}\text { Реалистичное восприятие, } \\
\text { опыт и притязания } \\
\end{array}$ \\
\hline Глубокие межличностные отношения & & $\begin{array}{c}\text { Способность к тёплым, } \\
\text { сердечным социальным } \\
\text { отношениям }\end{array}$ \\
\hline Общественный интерес & & Широкие границы Я \\
\hline \multicolumn{3}{|l|}{ Потребность в уединении } \\
\hline \multicolumn{3}{|l|}{ Демократический характер } \\
\hline \multicolumn{3}{|l|}{ Разграничение средств и целей } \\
\hline \multicolumn{3}{|l|}{$\begin{array}{c}\text { Вершинные, мистические } \\
\text { переживания } \\
\end{array}$} \\
\hline \multicolumn{3}{|l|}{ Сопротивление окультуриванию } \\
\hline Центрированность на проблеме & & \\
\hline
\end{tabular}

Таким образом, описывая недостаточно зрелых и самоакуализирующихся людей, авторы приводят в пример характеристики, противоположные заявленным. Инфантильные (незрелые) личности, относительно гуманистических концепций, не 
обладают достаточной автономией и независимостью от других, менее эффективно воспринимают реальность, критичны в отношении себя, имеют сложности с развитием творческих способностей, плохо ориентируются в том, что правильно, а что ошибочно, не всегда привержены какой-то задаче, долгу, не всегда руководствуются социальным интересом. Также незрелая, инфантильная личность не обладает самоприятием, не может объективно оценивать себя и реальность, не в полной мере понимает себя и не может относиться с юмором к себе и бытовым ситуациям, участвует в ограниченном круге деятельностей, винит в собственных неудачах внешние факторы, других людей.

Противоположностью инфантильности, как свойству личности, является зрелость личности - генерализованное качество, проявляющееся в постоянном развитии, ответственности, терпимости, способности строить зрелые межличностные отношения, позитивном отношении к миру.

Обобщая, можно заключить, что инфантильность в какой-то степени является нормальным этапом развития личности, но застревание на этом этапе, неспособность двигаться вперёд, развиваться дальше в будущем может создать серьёзные проблемы как для самого человека, так и для его окружения.

$$
* * *
$$

1. Абдрахимова Р.Г. Психическая инфантильность подросткового возраста в контексте современных тенденций / Р.Г. Абдрахимова // Научные исследования и разработки молодых учёных. - 2014. - № 2. С. 76-79.

2. Бакулина А.С. Социальный инфантилизм в контексте демографической ситуации в современной России / А.С. Бакулина // Человеческий капитал. - 2014. - № 5 (65). - С. 146-151.

3. Берн Э.Л. Игры, в которые играют люди. Люди, которые играют в игры / Э.Л. Берн. - М.: Эксмо, 2013. $-576 \mathrm{c}$.

4. Лебединский В. В. Нарушения психического развития в детском возрасте / В.В. Лебединский. - М.: Академия, 2003. - 144 с.

5. Маслоу А.Г. Мотивация и личность / А.Г. Маслоу. - СПб.: Питер, 2016. - 400 с.

6. Мельник С.Н. Психология личности / С.Н. Мельник. - Владивосток: ТИДОТ ДВГУ, 2004. - 96 с.

7. Олпорт Г.У. Становление личности: Избранные труды / Г.У. Олпорт. - М.: Смысл, 2002. - 462 с.

8. Роджерс К.Р. Гуманистическая психология. Теория и практика / К.Р. Роджерс. - М.: МОДЭК, НОУ ВПО Московский психолого-социальный университет, 2013. - 500 с.

9. Сидорова А.М. Философское понимание причин инфантилизма современной молодежи / А.М. Сидорова // Совет ректоров. - 2011. - № 1. - С. 61-66.

10. Фрейд 3. Введение в психоанализ / З. Фрейд. - М.: Пальмира, 2017. - 544 с.

11. Х Холл К.С. Теории личности / К.С. Холл, Л. Гарднер. - М.: Изд-во Института Психотерапии, 2008. - 672 c.

12. Хорни К. Невротическая личность нашего времени / К. Хорни. - М.: Академический Проект, 2009. $2008 \mathrm{c}$.

13. Эриксон Э.Г. Идентичность: Юность и кризис / Э.Г. Эриксон. - М.: Прогресс, 2006. - 352 с.

14. Юнг К.Г. Проблемы души нашего времени / К.Г. Юнг. - СПб.: Питер, 2017. - 336 с.

\section{Гайкина М.Ю., Коточигова М.В. \\ Мотивы противоправного поведения несовершеннолетних детей, совершающих мелкое хищение}

ФГБОУ ВО «Северный государственный медицинский университет» (Россия, Архангельск)

doi: $10.18411 / \mathrm{j}-08-2018-29$

idsp: 000001:lj-08-2018-29

\section{Аннотация}

Несовершеннолетние дети - одна из наиболее психологически уязвимых возрастных групп. В этот период, они еще не имеют достаточного опыта для взаимодействия с окружающим миром. Это приводит к появлению противоречий в 
неустойчивом сознании и возникновению асоциального поведения. Самовыражаясь, они противопоставляют себя обществу совершением общественно опасных деяний.

Ключевые слова: несовершеннолетние дети, мелкое хищение, мотивы, мотивационная направленность, мелкое хищение.

Детскую преступность без преувеличения можно отнести к разряду национальных бедствий. Социально-экономическая и духовно-нравственная ситуация современной России характеризуется нарастанием социального неблагополучия значительной части населения, падением жизненного уровня большинства семей, дистанцированием школы от детей с трудной судьбой, криминализацией среды их обитания, массовыми нарушениями прав несовершеннолетних. Подростковая преступность не существует сама по себе, а является своеобразным индикатором социальной ситуации в обществе, регионе [1]. Общество с высоким уровнем подростковой преступности обрекает себя на социально-нравственную деградацию с последующим разрушением общечеловеческих ценностей и устоев [2].

Вопросы борьбы с преступностью несовершеннолетних активно разрабатывались различными учеными. Значительный вклад в их исследование внесли Ю.М. Антонян, Н.И. Ветров, А.И. Долгова, В.Д. Ермаков, К.Е. Игошев, И.И. Карпец, В.Е. Квашис, В.Д. Ермаков, Н.И. Крюкова, Г.М. Миньковский, Н.Ф. Кузнецова, И.А. Горьковая, С.Я. Лебедев и др. Так на данный момент приоритетным является исследование мотивационного аспекта преступности несовершеннолетних, так как существующие классификации мотивов противоправного поведения подростков нуждаются в обновлении и дополнении.

Именно мотивационная направленность является одним из основных факторов, детерминирующих преступность несовершеннолетних: основное количество противоправных деяний совершается с целью удовлетворения жизненно важных потребностей. Мотив служит тем пусковым механизмом, который наполняет содержанием и направляет волевое действие человека [3].

Термин «мотив» применительно к противоправному поведению несовершеннолетних не используется и в основополагающих для деятельности основного правоприменительного в отношении них органа - комиссии по делам несовершеннолетних правовых актах - Федеральном законе № 120-Ф3 «Об основах системы профилактики безнадзорности и правонарушений несовершеннолетних» [4] и Примерном положении о комиссиях по делам несовершеннолетних и защите их прав, утвержденном Постановлением Правительства Российской Федерации от 6 ноября 2013 г. № 995 [5]. Традиционно одним из направлений противоправного поведения является совершение различного рода хищений чужого имущества. Это может быть и совершение преступлений различных категорий тяжести, и совершение административных правонарушений, предметом которых является чужое имущество. Одной из серьезных проблем подростковой среды является рост количества мелких хищений [6].

В связи с этим, особую актуальность сегодня приобретает исследование мотивации противоправного поведения несовершеннолетних детей, совершающих мелкое хищение.

Объект исследования: несовершеннолетние дети, совершившие мелкое хищение.

Предмет исследования: мотивы противоправного поведения несовершеннолетних детей, совершающих мелкое хищение.

Цель: исследовать мотивы противоправного поведения несовершеннолетних детей, совершающих мелкое хищение.

Задачи исследования:

1. Изучить теоретические аспекты изучения противоправного поведения несовершеннолетних детей.

2. Представить организацию работы отделения профилактики безнадзорности несовершеннолетних и семейного неблагополучия (ГБСУ АО «Архангельский социально-реабилитационный центр для несовершеннолетних»). 
3. Изучить мотивы противоправного поведения несовершеннолетних детей, совершающих мелкое хищение.

4. Разработать программу по совершенствованию социально-реабилитационной работы с несовершеннолетними с противоправным поведением в ГБСУ АО «Архангельский социально-реабилитационный центр для несовершеннолетних».

Гипотеза исследования: у несовершеннолетних, совершивших мелкое хищение, доминируют мотивы интереса и самоутверждения.

Методы исследования: аналитический (изучение и анализ научной литературы); социологический (анкетирование).

База исследования: ГБСУ АО "Архангельский социально-реабилитационный центр для несовершеннолетних" отделение профилактики безнадзорности несовершеннолетних и семейного неблагополучия.

Изучение особенностей преступности несовершеннолетних детей показало, что среди основных характеристик современного состояния подростковой преступности можно выделить ее высокую латентность, групповую направленность и появление признаков организованности. Таким образом детерминантой совершения преступлений является не только и не столько его объективные характеристики, но и субъективное восприятие данных факторов конкретным несовершеннолетним правонарушителем. Несмотря на важность и безусловную значимость объективных факторов возникновения подростковой преступности, нельзя не учитывать влияния субъективного восприятия несовершеннолетними различных реалий действительности, явлений, перечисленных выше, на первый взгляд, кажущихся не столь значительными, поскольку каждый правонарушитель обладает своим внутренним миром и уровнем развития личности. Крайне важна социальная профилактика правонарушений несовершеннолетних, которая включает первичную профилактику, направленную на установление обстоятельств, отрицательно влияющих на формирование личности несовершеннолетних и предотвращение их перехода на преступный путь; вторичную профилактику, устанавливающую обстоятельства, уже повлекшие совершение конкретных правонарушений несовершеннолетними; третичную профилактику, направленную на предупреждение рецидива правонарушений несовершеннолетними.

В Отделении профилактики безнадзорности несовершеннолетних и семейного неблагополучия (ГБСУ АО «Архангельский социально-реабилитационный центр для несовершеннолетних») с целью повышения профессиональной компетенции сотрудников ведется методическая работа. Специалистами отделения проводится патронаж, работа с несовершеннолетними и их родителями, проводится организаторская работа по летней занятости подростков. Налажено взаимодействие с различными учреждениями и организациями города.

Изучены мотивы противоправного поведения несовершеннолетних детей, совершающих мелкое хищение. Большинство подростков-правонарушителей впервые совершили мелкое хищение в возрасте 13-15лет. В основном, несовершеннолетние указывают следующие мотивировки своего противоправного поведения: «хотел доказать, что смогу»; «поступил из интереса». Это можно объяснить недостаточно сформированным самосознанием и безответственностью несовершеннолетних, неспособностью оценить последствия своих деяний, а также неприятием альтернативных, социально приемлемых вариантов самореализации. Совершение противоправных деяний «из интереса» свидетельствует о незанятости детей и предоставленности их самим себе в свободное от учебы время. Большая часть подростков, совершивших противоправные действия, продолжают поддерживать отношения с теми людьми, кто вовлек их или был причастен к организации и исполнению общественно опасного деяния. Более чем у половины несовершеннолетних правонарушителей родственники и друзья имеют проблемы с законом.

Разработана программа по совершенствованию социально-реабилитационной работы с несовершеннолетними с противоправным поведением в ГБСУ АО «Архангельский социально-реабилитационный центр для несовершеннолетних». Целью 
программы является коррекция недостатков социального развития указанной категории несовершеннолетних. Задачи программы носят комплексный характер, включают в себя образовательную, воспитательную, развивающую, здоровьесберегающую, социализирующую и культуротворческую функции. Целевая группа группы несовершеннолетних в возрасте от 12 лет до 17 лет. Программа включает 4 блока: «Правовое самосознание», «Молодежь - ЗА! Здоровый образ жизни!», блок Арттерапевтические сессии, Организация экскурсий, прогулок. Ожидаемый результат: реализация краткосрочной программы позволит развить у детей и подростков навыки социально приемлемого поведения, повысить образовательный и культурный уровень, освоить новые социальные роли, актуализировать положительные эмоциональные состояния, закрепить социально-значимые личностные качества, обогатить субъектный опыт, повысить уровень самооценки.

Рассматривая личность несовершеннолетних как фактор совершения правонарушений и учитывая особенности их общения, личные связи и вовлеченность в неформальную группу можно внести положительные коррективы или нейтрализовать детерминанты, способствующие неблагоприятному формированию личности подростка. Проблема преступности несовершеннолетних остаётся актуальной. Невозможно раскрыть сущность преступного поведения, объясняя его только лишь плохой наследственностью или низким социальным статусом родителей. Необходимо учитывать, как индивидуальные особенности личности, так и всю совокупность социальных и социально-психологических факторов, влияющих на нее.

$$
* * *
$$

1. Машинская Н.В. Современное состояние и предупреждение преступности несовершеннолетних (по материалам Архангельской области): Монография/ Н.В. Машинская. - Архангельск: Поморский университет, 2009. - 160 с.

2. Кудрявцев В.Н. Причины правонарушений/ В.Н. Кудрявцев. — М.: Норма: ИНФРА-М, 2017. — 288 с.

3. Баженов В.К. Профилактическая работа с несовершеннолетними правонарушителями/ В.К. Баженов. М.: Просвещение, 1994. - 326 с.

4. Федеральный закон № 120-Ф3 "Об основах системы профилактики безнадзорности и правонарушений несовершеннолетних". [Электронный ресурс]. - Режим доступа: http://base.garant.ru/12116087/\#ixzz53Ug2fuw9 (Дата обращения: 10. 12. 2017)

5. Об утверждении Примерного положения о комиссиях по делам несовершеннолетних и защите их прав: постановление Правительства Рос. Федерации от 6 ноя. 2013 г. № 995 [Электронный ресурс]. - Режим доступа: http://www.pravo.gov.ru. (Дата обращения: 10. 12. 2017)

6. Антонова Л.Б. Мотивы административных правонарушения несовершеннолетних в отношении чужого имущества/ Л.Б. Антонова //Общественная безопасность, законность и правопорядок в III тысячелетии. - 2015.- № 1.- С. 6-10

Зак А.3.

Особенности изменения сформированности когнитивных метапредметных компетенций у детей 10 - 11 лет

Психологический институт Российской академии образования

(Россия, Москва)

doi: $10.18411 / \mathrm{lj}-08-2018-30$

idsp: 000001:lj-08-2018-30

\section{Аннотация}

В статье представлено исследование, посвященное изучению характера динамики когнитивных метапредметных компетенций у пятиклассников. Раскрыта неравномерность динамики указанных компетенций: установлено опережающее формирование умения планировать, по сравнению с формированием познавательной рефлексии, и, тем более, с формированием эффективного способа решения поисковых проблем.

Ключевые слова: пятиклассники, когнитивные метапредметные компетенции, умение планировать, познавательная рефлексия, способ решения поисковых проблем. 


\section{Abstract}

The article presents a study on the nature of the dynamics of cognitive meta-subject competencies in fifth graders. The non-uniformity of dynamics of the specified competences is opened: the advancing formation of ability to plan, in comparison with formation of cognitive reflection, especially, with formation of an effective way of the solution of search problems is established.

Key words: children, cognitive competence, meta-subject, the ability to plan, cognitive reflection, a way to solve search problems.

Согласно положениям нового ФГОС ООО, в период обучения в средних классах школы у детей должны формироваться когнитивные метапредметные компетенции, связанные, в частности, с освоением и реализацией, во-первых, эффективных способов решения учебных и познавательных задач и проблем поискового характера, во-вторых, начальных и развитых форм познавательной рефлексии и связанных с ней умений осуществлять контроль своих действий, определять и корректировать их способы, втретьих, умения планировать пути достижения целей.

В понимании эффективности способов решения проблем, в трактовке форм познавательной рефлексии и умений определять и корректировать способы решения задач, в интерпретации характеристик сформированности умений планировать мы опирались на положения о двух видах познавательной деятельности, разработанные в диалектической логике [ 4 ] и реализованные в психологических исследованиях [ $1 ; 3$ ] .

Согласно этим представлениям, познание человеком окружающего мира может быть направлено на отражение внутренних связей предметов и явлений (теоретическое, содержательное, разумное, целостное познание) и на отражение их внешних связей (эмпирическое, формальное, рассудочное, частичное познание). В первом случае познавательная деятельность эффективна, поскольку ее результатом выступает понимание причин изменения объектов познания. Во втором случае познавательная деятельность малоэффективна, - еe результатом выступает лишь описание и упорядочивание наблюдаемых особенностей изменения познаваемых объектов.

Исходя из указанных представлений о двух видах познания, было принято [ 3 ], что разработка способа решения проблем в одном случае предполагает выделение существенных отношений в их условиях, в другом случае связь с существенными отношениями отсутствует. При выделении существенных отношений способы решения характеризуются как содержательные, обобщенные, поскольку обеспечивают решение всех задач некоторого класса; при отсутствии выделения существенных отношений способы решения характеризуются как формальные, частные, поскольку обеспечивают решение лишь отдельных задач некоторого класса.

Считалось, также, что познавательная рефлексия и умения определять и корректировать способы действий при решении задач могут быть связаны с обращением человека лишь к внешним особенностям способов действия или с обращением к основаниям способов действия. В первом случае познавательная рефлексия квалифицируется как формальная, внешняя, поскольку объектом обращения выступают наблюдаемые особенности способа действий. Во втором случае познавательная рефлексия квалифицируется как содержательная, внутренняя, поскольку объектом обращения в этом случае выступают скрытые, внутренние характеристики способа действий.

В рассмотрении характеристик планирования выделялись два вида программирования действий для решения задач. В одном случае составление плана может быть нацелено на разработку требуемой последовательности действий в целом. При этом все нужные действия намечаются до начала решения. В другом случае составление плана выполняется по частям: последующие действия намечаются после реализации предыдущих. В первом случае планирование будет целостным, содержательным, во втором - частичным, формальным. 
Формирование когнитивной метапредметной компетенции, связанной с освоением школьниками в ходе обучения способов решения проблем, предполагает освоение ими мыслительного действия анализа, который связан с разбором условий достижения требуемого результата. В одних случаях такой разбор реализуется как формальный анализ, лишь расчленяющий предложенные условия на отдельные данные, - это характерно для необобщенного, эмпирического способа решения проблем $[1 ; 3]$.

В других случаях разбор условий связан не только с выделением данных и их отношений, но и, главное, с выяснением их роли в успешном решении: что́ из них существенно и необходимо, а что несущественно и случайно. Это содержательный, выясняющий анализ, выступающий условием обобщенного, содержательного способа решения проблем.

Освоенность обобщенных способов достижения требуемого результата характеризуется возможностью осуществлять содержательный анализ предложенных условий, связанный с выделением существенных отношений данных. В результате успешно решаются все проблемы данного класса. Факт неуспешного решения одной или нескольких из них свидетельствует об отсутствии содержательного анализа и, следовательно, о наличии необобщенного способа решения предложенных проблем.

На основе представлений о своеобразии разных подходов к разбору условий проблем, относящихся к одному классу, и связанных с этими подходами разных способов их решения были разработаны требования к экспериментальной ситуации, предназначенной для определения характера способа действий (обобщенный или необобщенный, частный) при достижении требуемого результата.

Во-первых, испытуемому необходимо предлагать для решения не одну, а несколько проблем; во-вторых, эти проблемы должны иметь общий принцип построения и решения; в-третьих, их условия должны различаться внешними, непосредственно наблюдаемыми особенностями.

Освоение в ходе обучения начальных форм познавательной рефлексии выступает условием формирования у школьников умения осуществлять контроль и коррекцию своих действий. В зависимости от того, с какой целью осуществляются рефлексия, контроль и коррекция, различают два уровня их реализации, проявляющейся в рассмотрении школьником способов своих действий $[1 ; 3]$.

Если такое рассмотрение производится, чтобы узнать, какие конкретно операции нужно выполнить, чтобы получить требуемый результат, то считается, что здесь школьник ориентируется лишь на внешние характеристики своих действий.

Это характеризует формальный уровень реализации рассматриваемых действий, поскольку здесь отражается зависимость способов действий от случайных и единичных условий достижения требуемого результата. В этом случае школьник, ориентируясь при успешном решении задач, - имеющих объективно общий принцип построения, — на внешнее сходство особенностей их условий, может сгруппировать их формально, а, ориентируясь на внешнее различие этих особенностей, может вообще отказаться от группировки задач, считая их разными.

Если же рассмотрение способов действий осуществляется с тем, чтобы узнать, почему данное действие выполняется так, а не иначе, понять причины его успешного выполнения при решении разных задач, то тогда школьник осмысливает способ своих действий, опираясь на его скрытые, прямо не наблюдаемые характеристики, и может, поэтому, обобщать действия содержательно.

Такой уровень осмысления связан с реализацией содержательных рефлексивных действий, поскольку вскрывается связь способа действий с существенными условиями их выполнения. В этом случае ориентировка на внутреннее, существенное единство задач, имеющих общий принцип построения, позволяет сгруппировать их содержательно.

Для определения вида рефлексивных действий при решении задач разработана специальная экспериментальная ситуация. В ее первой части предлагается решить несколько задач, которые, во-первых, относятся не к одному, а к двум классам, - это 
означает, что часть задач решается на основе одного принципа, а часть - на основе другого, и, во-вторых, условия задач различаются внешними особенностями.

Во второй части этой экспериментальной ситуации задачи предлагалось сгруппировать. По характеру группировки определялось наличие или отсутствие реализации содержательных рефлексивных действий.

Если за основание группировки принималась существенная общность способов решения задач, то, значит, при решении осуществлялись содержательные рефлексивные действия, а если группировка основывалась на внешнем сходстве условий задач, то, значит, при решении осуществлялись формальные рефлексивные действия.

Таким образом, сформированность рефлексивных действий характеризуется возможностью школьника раскрывать существенную общность способов своих действий при решении задач одного рода и выделять принципиальное различие реализованных способов при решении задач разного рода.

Формирование умения планировать пути достижения цели связано с освоением действий во внутреннем плане, которые выступают условиями построения программы шагов по достижению требуемого результата. При решении задач планирование осуществляется по-разному [ $1 ; 3]$.

В одном случае достижение цели планируется по отдельным звеньям, которые при этом не связываются в единую систему. Требуемый результат получается, таким образом, путем проб и ошибок, когда операции планирования чередуются с выполнением отдельных действий по достижению цели. Это формальное, частичное планирование, характерное для реализации необобщенного способа решения задач.

В другом случае последующие действия для получения требуемого результата намечаются одновременно с предыдущими, а предыдущие действия планируются с учетом возможных вариантов выполнения последующих. Это содержательное, целостное планирование, характерное для обобщенного способа решения задач.

В соответствии с изложенными представлениями была разработана специальная двухчастная экспериментальная ситуация. В первой ее части испытуемому предлагается освоить некоторое простое действие, во второй части требуется решить несколько задач на построение последовательности этих действий.

Подбор задач во второй части должен отвечать ряду требований: во-первых, последовательность исполнительных действий должна постепенно возрастать от первой задачи к последней; во-вторых, задач с одинаковым числом исполнительных действий должно быть не меньше двух; в-третьих, задачи не должны иметь общего принципа решения, чтобы нужно было каждый раз мысленно экспериментировать, заново разрабатывая все возрастающую последовательность действий.

Основываясь на изложенных представлениях о видах когнитивных метапредметных компетенций, отражающих способы решения поисковых проблем, познавательную рефлексию и планирование, была разработана методика «Перестановки». Это методика предназначена для определения уровней сформированности отмеченных компетенций у школьников.

Групповое диагностическое занятие на материале задач методики «Перестановки» проводилось с 53 пятиклассниками в начале учебного года (сентябрь) и в его конце (май). Оно было организовано следующим образом.

Сначала организатор занятия раздает детям листы для ответов, на которых они указывают свою фамилию.

Затем организатор чертит на классной доске игровые поля, проставляя слева цифры, а снизу буквы (рис.1).

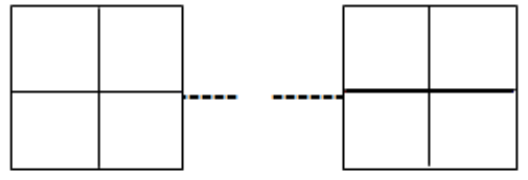

Рисунок 1. Игровые поля 
Детям объясняют названия клеток игрового поля (его нотацию): «В обоих квадратах каждая клетка имеет название из буквы и цифры. Две нижние клетки называются A1 и Б1, а две верхние - А2 и Б2».

Далее клетки обоих игровых полей заполняются объектами. В игровом поле слева размещается начальное расположение объектов - пары одинаковых фигур. Эти объекты будут перемещаться. В игровом поле справа - конечное расположение объектов - пары одинаковых цифр, - эти объекты не будут перемещаться (рис.2).

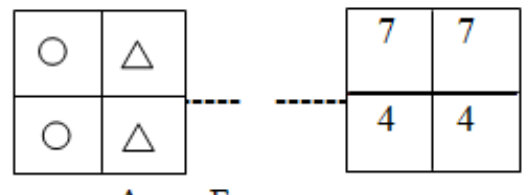

A $\mathrm{B}$

Рисунок 2. Условие задачи 1

Затем организатор говорит: «В этой задаче нужно какие-то две фигуры мысленно поменять местами так, чтобы одинаковые фигуры оказались в тех же клетках, что и одинаковые цифры.

Кто скажет, какие фигуры можно поменять местами?»

Оценив предложенные учениками варианты обмена фигур организатор показывает на доске с правой стороны, как следует записывать решение задач в одно действие (рис.3).
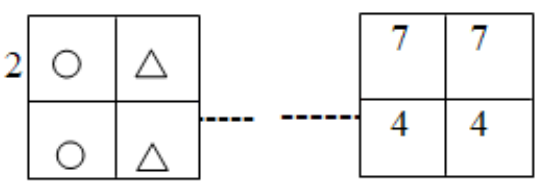

A $\mathrm{B}$
1) $\mathrm{A} 1-\mathrm{B} 2$

$$
\text { 1) } \mathrm{A} 2-\mathrm{B} 1
$$

Рисунок 3.Решение задачи 1

При этом поясняется смысл найденного решения: «Если меняются местами круг из A1 с треугольником из Б2, то одинаковые фигуры окажутся в тех же клетках, где одинаковые цифры: два круга будут в верхних клетках, - там, где семерки, а два треугольника будут в нижних клетках, - там, где четверки. Здесь решение нужно записать так: А1 - Б2. А если меняются местами круг из А2 с треугольником из Б1, то треугольники будут там, где семерки, а круги там, где четверки, и решение записывается так: А2 - Б1

Далее на доске изображается условие задачи в два действия (рис.4).

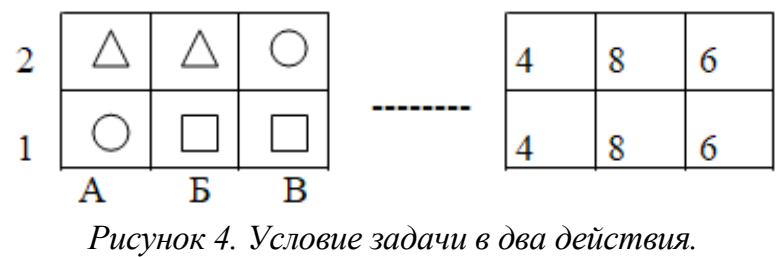

В этой задаче нужно найти два действия, чтобы одинаковые фигуры были в тех же клетках, где одинаковые цифры».

Обсудив предложенные детьми варианты первого и второго действий, организатор записывает одно из решений, например: 1) А2-B2, 2) Б2-B1 (рис.4) и поясняет его смысл: «Сначала, - первым действием, - можно поменять местами круг и треугольник в угловых верхних клетках, - A2 и В2. Тогда круги будут там, где четверки, а треугольник будет в клетке В2. Потом, - вторым действием, - этот треугольник можно поменять местами с квадратом из Б1. Тогда треугольники будут там, где восьмерки, а квадраты, где шестерки ...».

Затем организатор указывает: «Если в задаче несколько решений, как в этой, то нужно писать только один вариант...».

Далее ученикам раздаются листы с условиями 12 задач (рис.5). 
ЗАДАНИЕ 1
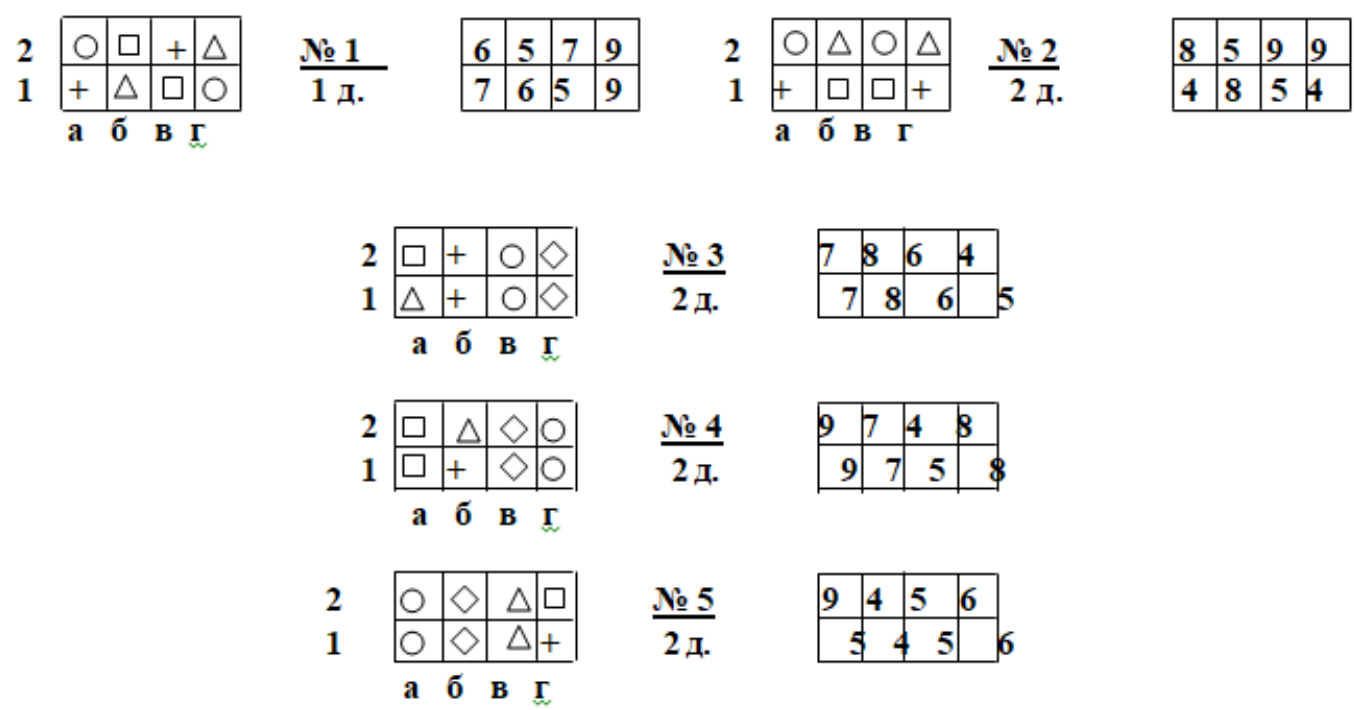

Мнения о задачах

Несколько учеников 4 класса решили эти задачи и обменялись мнениями.

Таня сказала: «Задачи 3, 4 и 5 похожи».

Коля не согласился: «Задачи 3, 4 и 5 разные».

Вика: «Думаю, что похожи задачи 3 и 4 , а задача 5 от них отличается».

Катя: «Считаю, что похожи задачи 3 и 5 , а задача 4 от них отличается».

Нина: «Уверена, что похожи задачи 4 и 5 , а задача 3 от них отличается».

Кто из учеников прав?

ЗАДАНИЕ 2

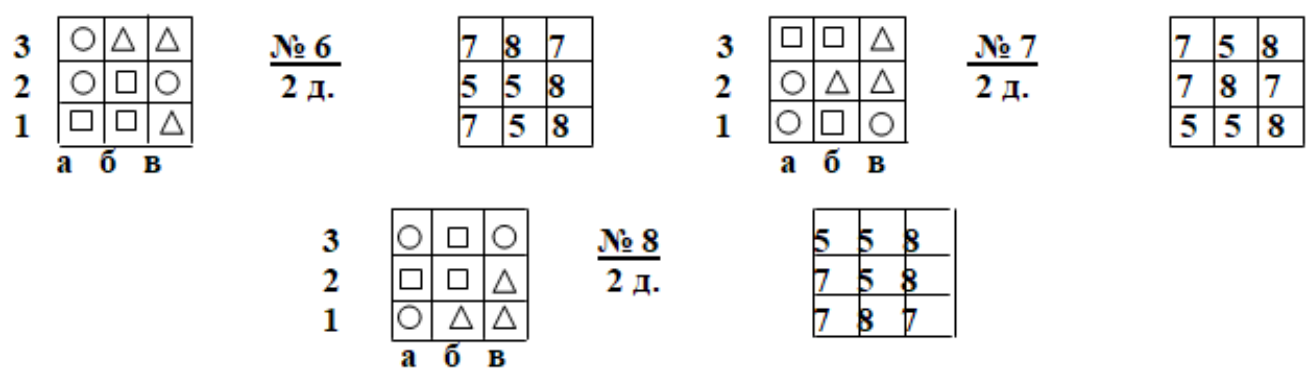

ЗАДАНИЕ 3

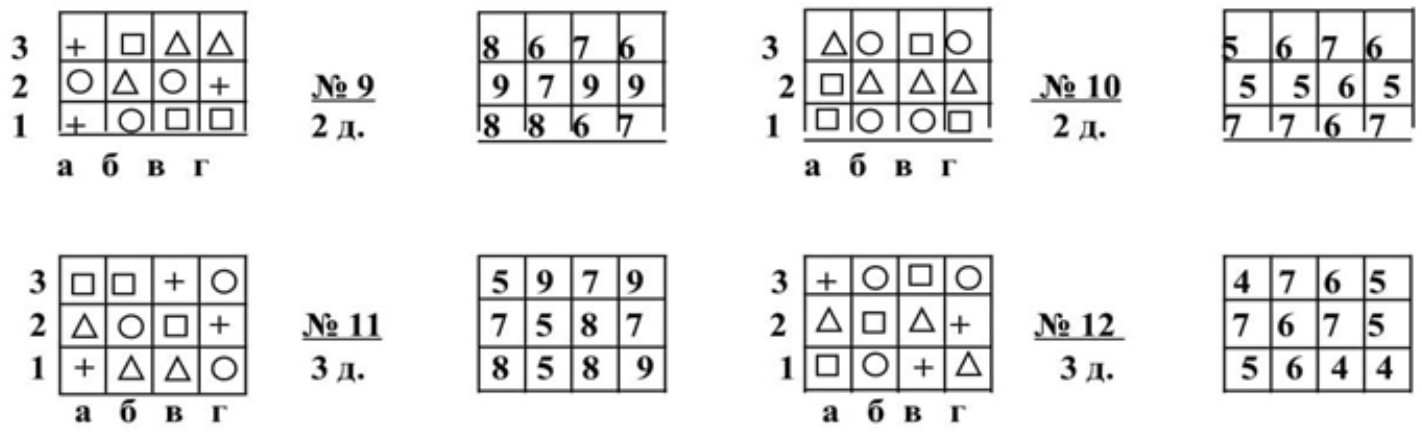

Рис.5. Лист с задачами.

Затем организатор характеризует расположение задач на бланке: «Посмотрите на лист с задачами. В первом задании сначала нужно решить задачи №1 и 2, а потом задачи №3, 4 и 5. После этого нужно прочитать мнения учеников об этих трех задачах и на листе с ответами выбрать и отметить имя того ученика, чье мнение для вас самое верное. Во 
втором задании нужно решить три задачи в два действия. В третьем задании нужно решить 4 задачи: две в 2 действия и две в три действия».

После этого организатор характеризует содержание листа с ответами: «Посмотрите на лист с ответами. Вверху напоминается, что каждая клетка обозначается буквой и цифрой, например: А2, Б3 или В1, и что действие по обмену фигур записывается так, как было при решении задач на доске, - указываются названия двух клеток, например, А1 - А2 или Б3 - В1.

Затем имеется место, чтобы записать одно действие по решению задачи 1 и два действия по решению задач 2, 3, 4 и 5.

Далее нужно выбрать и отметить мнение того ученика, чье мнение о задачах 3, 4 и 5 для каждого из вас самое верное.

Во втором задании нужно записать два действия по решению задач 6,7 и 8 .

В третьем задании нужно записать два действия по решению задач 9 и 10 и три действия по решению задач 11 и 12».

В заключении инструктирования детям поясняется:

«Задачи решайте подряд, начиная с первой:

- условия задач не срисовывайте,

- ищите и записывайте только один вариант решения;

- нельзя делать никаких пометок на листе с условиями задач, а также на столе и любых бумажках.

Задачи решайте только мысленно, в уме, как примеры на сложение при устном счете. Действуйте внимательно и самостоятельно».

При обработке результатов решения задач основаниями выступали следующие положения.

Задание 1 предназначено для определения уровня освоения начальных форм познавательной рефлексии при решении задач в наглядно-образной форме. Детям нужно решить три задачи (две построены по одному принципу, одна - по другому) и выбрать одно мнение о них из пяти предложенных.

Если верно решив три задачи, ребенок выбирает 1-е, 2-е, 3-е или 5-е мнение, то в этом случае считалось, что при решении имела место формальная рефлексия.

Если верно решив три задачи, ребенок выбирает 4-е мнение, то в этом случае считалось, что имела место при решении содержательная рефлексия.

При отсутствии верного решения всех трех данных задач считалось, что выбор 4го мнения не свидетельствует о наличии как формальной, так и, тем более, содержательной рефлексии.

Задание 2 предназначено для определения уровня освоения способов решения проблем поискового характера при решении задач в наглядно-образной форме. Детям нужно решить три задачи (построенные по единому принципу).

Если ребенок решил верно все три задачи, то в этом случае считалось, что решение основано на выделении существенных отношений, лежащих в основе единого принципа решения, - это означает, что решение осуществлялось общим способом.

Если ребенок не решил три задачи, а решил верно любые две или одну из трех задач, то в этом случае считалось, что решение не основано на выделении существенных отношений, лежащих в основе единого принципа решения, - это означает, что решение осуществлялось частным способом.

При отсутствии решения хотя бы одной задачи считалось, что способ решения отсутствовал, т.е. вообще не был найден.

Задание 3 предназначено для определения уровня развития способности действовать «в уме» как исходной для формирования у детей умения планировать, контролировать и оценивать учебные действия. Детям нужно решить четыре задачи, оперируя значительным числом элементов условий в мысленном плане.

Если все задачи решены неверно, то имеет место проявление нулевого уровня развития способности действовать «в уме». В этом случае считалось, что имело место отсутствие планирования. 
Если верно решена любая одна задача, то имеет место проявление первого уровня развития данной способности.

Если верно решены любые две задачи, то имеет место проявление второго уровня развития данной способности. Если верно решены любые три задачи, то имеет место проявление третьего уровня развития данной способности. Первый, второй и третий уровни квалифицировались как реализация частичного планирования.

Если верно решены четыре задачи, то имеет место проявление четвертого уровня развития данной способности. В этом случае считалось, что осуществилось целостное планирование.

Как отмечалось, в исследовании участвовали 53 пятиклассника. Результаты решения задач методики «Перестановки» в начале и конце учебного года представлены в таблице 1.

Результаты решения задач методики «Перестановки» пятиклассниками

Таблицуа 1. в начале (сентябрь) и конще (май) учебного года (в \%).

\begin{tabular}{|c|c|c|c|}
\hline $\begin{array}{c}\text { Время } \\
\text { диагностики }\end{array}$ & $\begin{array}{c}\text { Общий } \\
\text { способ решения }\end{array}$ & $\begin{array}{c}\text { Содержательная } \\
\text { рефлексия }\end{array}$ & $\begin{array}{c}\text { Целостное } \\
\text { планирование }\end{array}$ \\
\hline Сентябрь & 49,1 & 9,4 & 11,3 \\
\hline Май & 60, & 22,6 & 26,2 \\
\hline
\end{tabular}

Данные, представленные в таблице 1, свидетельствуют о следующем.

В итоге года обучения увеличилось число детей, проявивших при решении задач возможность применять общий способ (на 11,0\%), содержательную рефлексию (на 13,2\%) и целостное планирование (на 14,9\%). Эти данные позволяют утверждать, что, (подобно тому, что имеет место при обучении детей в начальной школе [ 2 ]), на первом году обучения в средних классах число детей, применяющих при решении задач целостное планирование, также увеличивается более интенсивно, чем число детей, применяющих при решении задач содержательную рефлексию и, тем более, чем число детей, применяющих при решении задач общий способ.

В дальнейших исследованиях планируется установить особенности динамики рассматриваемых когнитивных метапредметных компетенций при обучении детей в шестом классе.

$$
* * *
$$

1. Давыдов В. В. Теория развивающего обучения. М.: Интор, 1996. 643 с.

2. Зак А.З. Мышление младшего школьника. Спб.: Содействие, 2004. 829 с.

3. Зак А.З. Развитие и диагностика мышления подростков и старшеклассников. М.; Обнинск: ИГСОЦИН, 2010. $350 \mathrm{c}$.

4. Ильенков Э. В. Диалектическая логика: очерки истории и теории. М.: Наука, 1984.427 с.

\section{Просекова Е.Н. \\ Особенности развития самосознания в ранней юности}

ФГБОУ ВО «Шадринский государственный педагогический университет» (Россия, Шадринск)

doi: $10.18411 / 1 j-08-2018-31$

idsp: 000001:lj-08-2018-31

\section{Аннотация}

В статье осуществлен краткий теоретический анализ основных направлений в изучении самосознания личности. Рассмотрены наиболее значимые особенности формирования самосознания в ранней юности.

Ключевые слова: ранняя юность, развитие самосознания, я-концепция, самопознание, самооценка, саморегуляция. 
Abstract

The article provides a brief theoretical analysis of the main directions in the study of selfconsciousness. The most significant features of self-consciousness formation in early youth are considered.

Keywords: early youth, development of self-awareness, self-concept, self-knowledge, self-esteem, self-control.

На современном этапе развития психологической науки одной из наиболее актуальных проблем научного сообщества является формирование важнейшего составного компонента личности - самосознания. Политическая, экономическая, социальная нестабильность и нравственно-смысловая неопределенность, сложившаяся в настоящее время в российском обществе, приводят к возникновению различных отклонений в личностном развитии, что особенно ярко прослеживается в юношеском возрасте.

Тематике самосознания личности посвящено значительное количество теоретических и экспериментальных работ, как в нашей стране, так и за рубежом. Исследования ученых в основном сконцентрированы вокруг таких проблем как: познание сути феномена самосознания и сопоставление его с понятиями «Я-образ», «Я-концепция», «Я-система» (К.А. Абульханова-Славская, Р. Бернс, Б.С. Братусь, Л.С. Выготский, У. Джеймс, А.Н. Леонтьев, К. Роджерс, С.Л. Рубинштейн, В.В. Столин и др.); создание разнообразных моделей самосознания и описание их элементов (В.С. Агапов, Р. Бернс, И.С. Кон, В.С. Мухина, Ж.И. Намазбаева, А.Б. Орлов, К. Роджерс, В.В. Столин, П.Р. Чамата, И.И. Чеснокова, S. Samuel, R. Wylie и др.); постижение этапов становления самосознания в контексте проблемы развития личности (Л.И. Божович, А.Н. Леонтьев, И.И. Чеснокова, С.Л. Рубинштейн и др.); выделение этапов процесса самосознания и изучение условий, оказывающих определяющую в нем роль (Л.И. Божович, В.С. Мухина, А.А. Налчаджан, Д.Б. Эльконин и др.).

Анализ теоретических положений наличествующих в современном научном мире позволил сделать вывод, что одним из наиболее значимых новообразований ранней юности является формирование самосознания в его высшей форме, следовательно, именно благополучная реализация данного процесса образует базу для адекватного развития личности в данный период онтогенеза.

В психологии развития ранний юношеский возраст характеризуется, прежде всего, как период, в котором человек впервые начинает искать всеобъемлющие жизненные принципы и ценности. На данном этапе происходит становление мировоззрения, личностного и профессионального самоопределения, приобретается психологическая и эмоциональная автономия. По мнению авторов (Р. Бернс, Л.И. Божович, Л.С. Выготский, К. Обуховский и др.) юноши и девушки начинают выстраивать жизненные и временные перспективы $[1,2,5,9]$. Именно на этом этапе развития впервые начинаются поиски смысла собственной жизни (Ш. Бюлер, В. Штерн, Э. Эриксон, К. Обуховский, Л.И. Божович, И.С. Кон, Г.А. Вайзер и др.) [8]. Несомненно, что за данными преобразованиями следуют процессы, нацеленные на построение собственной личности. По мысли И.С. Кона: «открытие своего внутреннего мира равнозначно для юноши настоящей «коперниковской революции» [7].

В исследованиях особенностей самосознания в юности (Э. Эриксон, Р. Бернс, К. Роджерс, Дж. Марсиа, Л.И. Божович, В.В. Столин, С Г. Якобсон и др.) авторы отмечают глобальные изменения в «Я-концепции» молодых людей. Исследователи признают иерархичность и многомерность «Я-концепции», включая в нее обширный круг репрезентаций: представление о себе, эмоционально-ценностное отношение, самооценку и пр.

Р. Бернс утверждает, что «Я-концепция» - это совокупность всех представлений индивида о себе, сопряженная с их оценкой [1]. Он выделил четыре составляющих «Яконцепции», позволяющих конкретизировать ее содержательную сторону: когнитивную, описательную, оценочную и поведенческую.

J. Marcia [12] и Ф.Е. Василюк [4] в своих исследованиях отмечают интенсивное развитие образа «Я-будущее», в качестве существенной особенности появления в образе «Я» ценностной и нравственной составляющих. Осознание, что личностные ценности в будущем могут измениться по сравнению с актуальными на данный момент 
приоритетами, связано с появлением у юношей и девушек в «Я-образе» трансцендентальных ценностей.

Л.С. Выготский называл развитие самосознание в ранней юности «самой последней и верхней из всех перестроек», которая приводит к открытию и овладению внутренним миром. «Недаром внешним коррелятом этого события, - пишет он, - является возникновение жизненного плана...» [5]. Важно отметить, что именно в ранней юности перед молодыми людьми впервые встает проблема противоречия «Я-реального» и «Ябудущего». У юношей и девушек начинается активный поиск сути, какими оно хотят стать, что обнаруживается в проявлении жизненной перспективы $[3,9]$.

У юношей и девушек устремленность в будущее ярко отражается в личностном и профессиональном самоопределении.

Личностное самоопределение молодых людей имеет ценностно - смысловую природу. На данном этапе развития у юношей и девушек происходит установление собственной позиции относительно социально сформированной системы ценностей, с последующим определением смысла своего собственного существования.

Профессиональное самоопределение - это выбор конкретной трудовой деятельности, которая является главным средством утверждения чувства собственного достоинства как состоявшейся личности.

Также на данном этапе развития предельно актуализируется проблема расхождения «Я-реального» и «Я-идеального», что является функцией не только возраста, но и интеллекта. И.С. Кон отмечает, что несовпадение образов взаимосвязано с когнитивным развитием [8]. Чем старше по уровню развития молодые люди, тем более значимым для них является психологическое содержание действительности, при этом «внешний» событийный контекст становится менее ценным. У интеллектуально развитых юношей и девушек расхождения между данными образами проявляются намного чаще, чем у их сверстников со средними и низкими интеллектуальными способностями [1].

В развитии самосознания, как и любого сложного психологического новообразования исследователи выделяют несколько онтогенетических стадий, последовательно сменяющих друг друга. В ранней юности самосознание личности можно рассматривать как дебют формирования нового уровня, как этап углубления и совершенствования интегративных качеств. Также на данном этапе развития можно выделить специфические черты значимые для формирования «Я-концепции», а именно возникновение новой концепции собственных ценностей, углубление психологического, личностного и динамического аспекта восприятия. Все это позволяет оценивать данный уровень, как уровень развития зрелой личности.

Следует отметить, что в ранней юности становление нового уровня самосознания осуществляется по направлениям выделенными Л.С. Выготским, происходит интегрирование образа самого себя, «перемещение» его «извне вовнутрь». В это время происходит смена «объективистского» взгляда на себя «извне» на субъективную динамическую позицию «изнутри». Именно это вызывает процессы осмысления собственных мыслей, чувств, действий, поступков [5]. Таким образом, при переходе от частных самооценок к общей целостной (смена оснований) создаются условия для формирования собственного отношения к себе, независимого от оценок и отношения окружающих.

В самооценке, как сложноструктурированном психологическом образовании, выделяют два основных функционирующих в неразрывном единстве компонента: когнитивный и эмоциональный.

Когнитивный компонент самооценки отражает знание человека о себе, различной степени оформленности и обобщенности.

Эмоциональный компонент самооценки - это эмоциональное отношение человека к себе, накапливающийся у него «эффект на себя», связанный с мерой удовлетворенности своими действиями, результатами реализации намеченных целей [1].

В юношеском возрасте когнитивный и эмоциональный компоненты самооценки характеризуются достаточно сбалансированным развитием. Осознанные знания юношей и девушек о себе регулируют и ведут за собой эмоции, адресующиеся собственному «Я». Также следует отметить, что для юношей и девушек самооценка выполняет значимую роль в организации эффективной саморегуляции поведения. Однако только адекватная 
самооценка молодых людей позволяет критически относиться к себе, рационально соотносить свои силы с задачами и требованиями окружающих. При негативной самооценке происходит «непринятие себя», самоотрицание, формируется негативное отношение к своей личности. В своих работах Л. Пепло, М. Мицели и Б. Морали высказывают мнение о том, что низкая самооценка может быть и причиной и следствием одиночества [10]. Также негативная самооценка нивелирует уровень притязаний и ограничивает жизненные перспективы юношей и девушек [1].

Еще одной из важнейших составляющих самосознания в ранней юности является самоуважение, которое определяет адекватность молодых людей в окружающем мире. Самоуважение понятие далеко неоднозначное, так как включает в себя множество аспектов, это и положительное отношение к себе, и удовлетворенность собой, и принятие себя, и чувство собственного достоинства, и согласованность образов «Я-реального» и «Я-идеального». Высокий уровень самоуважение ассоциируется с позитивными эмоциями, а низкий - с негативными. И.С. Кон определяет мотив самоуважения следующим образом: «это личная потребность максимизировать переживание положительных и минимизировать переживание отрицательных установок по отношению к себе» [6].

Также самоуважение зависит и от успеха и от уровня притязаний личности: чем выше уровень притязаний, тем сложнее их удовлетворить, что приводит к снижению уровня самоуважения. Чем более выражен успех в деятельности, тем выше самоуважение человека.

В юношеском возрасте степень самоуважения определяет личность. Самоуважение личности выступает условием ее максимальной активности, продуктивности в деятельности, влияет на свободу выражения чувств, реализацию творческого потенциала, уровень самораскрытия в общении [11].

Юноши и девушки с высоким уровнем самоуважения считают себя не хуже других, верят в себя, в собственные силы и в то, что могут преодолеть все свои недостатки. Они не боятся идти к высоким достижениям и успеху в любой области жизни. Низкий уровень самоуважения, наоборот, создает постоянное ощущение ущербности, неполноценности, что крайне отрицательно влияет на эмоциональное самочувствие и социальное поведение молодых людей. Юноши и девушки вследствие собственной неуверенности избегают деятельности, в которой имеется момент соперничества и зачастую отказываются от достижения поставленных целей.

Таким образом, на основании анализа результатов исследования можно констатировать, что самосознание в ранней юности приобретает качественноспецифический характер. Особенности самосознания юношей и девушек тесно взаимосвязаны с необходимостью молодых людей оценивать качества своей личности с учетом конкретных жизненных намерений, в связи с увеличением задач личностного и профессионального самоопроделения.

$$
* * *
$$

1. Бернс Р. Я-концепция и Я-образы // Самосознание и защитные механизмы личности. Хрестоматия. / Р. Бернс - Самара: Изд. Дом "Бахрах М", 2003. - 656 с.

2. Божович Л.И. Избранные психологические труды /Л.И. Божович / Проблемы формирования личности: Под ред. Д.И. Фельдштейна - Издание 2-е, стереотипное. - М.: Издательство "Институт практической психологии", Воронеж: НПО "МОДЭК", 1997. - 351 с.

3. Братусь Б.С. Смысловые сферы личности / Б.С. Братусь // Психология личности: Хрестоматия / под ред. Д.Я. Райгородского. - М.: Изд. Дом "Бахрах М", 2000. - С. 385 - 456.

4. Василюк Ф.Е. Структура образа / Ф.Е. Василюк // Вопр. психол. - 1993. - № 5. - С. 5 - 19.

5. Выготский Л.С. Педология подростка: проблема возраста // Л.С. Выготский. / Собр. соч.: В 6 т. Т. 4. / под ред. Д.Б. Эльконина. - М.: Педагогика, 1984. - 433 с.

6. Кон И.С. В поисках себя: личность и ее самосознание / И.С. Кон. - М.: Политиздат, 1984. - 335 с.

7. Кон И.С. Открытие Я / И.С. Кон. - М., 1978. - 367 с.

8. Кон И.С. Психология ранней юности / И.С. Кон. - М: Просвещение. $-1989 .-255$ с.

9. Обуховский К. Психология влечений / К. Обуховский. - М.: Прогресс, 1972. - 248 с.

10. Пепло, Л.; Мицели, М.; Морали, Б. Одиночество и самооценка / Самосознание и защитные механизмы личности / Самара: Изд. дом “Бахрах”, 2003. - 656 с.

11. Роджерс К. Взгляд на психотерапию. Становление человека / К. Роджерс. - М.: Прогресс, 1994. - 480 c.

12. Marcia J.E. Identity in adolescence // J. Adelson (Ed.), Handbook of adolescent psychology. New York: John Wiley, 1980. - pp. 159-187. 


\section{РАЗДЕЛ ІІІ. СОЦИОЛОГИЯ}

\section{Плеханова О.В. \\ Средства формирования имиджа местного самоуправления}

Рязанский государственный университет имени С.А. Есенина

(Россия, Рязань)

doi: $10.18411 / \mathrm{j}-08-2018-32$

idsp: 000001:lj-08-2018-32

\section{Аннотация}

В статье рассматриваются особенности средств формирования имиджа органов местного самоуправления. Муниципальная власть, как и вся власть в целом, предназначена для удовлетворения каких-то потребностей жителей муниципального образования. Отмечается важность формирования у населения позитивного образа. Делается вывод, что укрепление взаимоотношений между этими субъектами позволит обеспечить желаемую реакцию на проводимую социально-экономическую политику со стороны населения муниципалитета. Именно поэтому формирование положительного имиджа органов местного самоуправления является весьма актуальной проблемой в наши дни.

Ключевые слова: имидж, местное самоуправление, репутация, муниципалитет, общественное мнение, авторитет, доверие.

Формирование имиджа - это сложный динамический процесс, который характеризуется тем, что не имеет окончательного результата, пока учреждение еще существует. По сути, имидж - это стратегия, состоящая из инструментов маркетинга, использующихся для достижения определенной цели.

Специфичность имиджа как составляющая администрации проявляется в том, что он существует не зависимо от усилий самого учреждения - он есть, даже если и не разрабатывается специально - и поэтому постоянно нуждается в оценке и корректировке.

Задача формирования положительного имиджа органа исполнительной и законодательной власти входит в компетенцию пресс-служб или служб по связям с общественностью. Необходимость целенаправленного формирования имиджа органов местного самоуправления объясняется тем, что стихийное формирование имиджа происходит под воздействием случайной информации, иногда и под влиянием черных PR-технологий и, чаще всего, не соответствует тому образу, который руководство учреждения хотело бы иметь. Поэтому, такой имидж редко бывает благоприятным.

Следующим образом может быть представлена структура формирования именно стихийного имиджа:

— обычная, проходная информация о деятельности администрации;

— публикации сенсационного и разоблачительного характера;

- слухи о деятельности органа местного самоуправления;

— личные наблюдения жителей, полученные в результате прямого контакта с подразделениями и сотрудниками муниципальной администрации.

Формирование целенаправленного имиджа содержит следующие этапы:

1) выявление уже сложившихся образов у населения муниципального образования об администрации;

2) формирование определения того, каким хотели бы видеть местную администрацию жители и что они ожидают от ее деятельности;

3) конструирование имиджа данного объекта как ответ на ожидания и предпочтения населения;

4) практическая деятельность конкретно по формированию имиджа, т.е. перевод модели в реальность;

5) исправление модели в процессе реализации; 
6) осуществление мониторинга по сформированному имиджу, деятельность по его поддержанию и улучшению.

Положительный имидж для администрации муниципального образования, по мнению исследовательницы Гордеевой О.В., должен обладать рядом важных характеристик, таких как пластичность, оригинальность, адекватность и иметь точный адрес.

Пластичность подразумевает, что имидж должен постоянно совершенствоваться, не устаревать, изменяясь, казаться неизменным. Оригинальный имидж предполагает, что имидж администрации должен отличаться от образов других организаций. Под адекватным имиджем понимается соответствие уже существующему образу, специфике или сфере деятельности предприятия. Иметь точный адрес означает, что имидж должен привлекать обозначенную целевую аудиторию.

Так как репутация администрации складывается из целого комплекса, поэтому требует регулирование во многих областях как внутренних, относящихся к делам внутри учреждения, так и внешних, ориентированных на работу с населением.

Контроль над имиджем характеризуется следующими свойствами: открытость администрация нуждается в честной, достоверной и полной информации, которая описывает ее имидж, а это может стать возможным в том случае, если ведется открытый диалог с населением; долговременность - этот процесс построения имиджа предполагает единую стратегию, которая рассчитана на долгий срок, а не краткосрочные меры, например мероприятия или акции; оперативность - современные потребители формируют свое мнение об учреждении, исходя не только из качества обслуживания, но и из того, как быстро реагируют на их запросы и потребности; использование нескольких инструментов - реклама, PR, маркетинг - то есть все инструменты интегрированных маркетинговых коммуникаций будут задействованы для достижения поставленных коммуникативных целей; комплексный подход - только полный охват инструментов будут эффективно влиять на характер имиджа.

Э. И. Абенова в своей работе отмечает, что система управления имиджем имеет следующие шаги:

1) исследовательский. На этом этапе необходимо изучить общий имидж администрации, ее внешнюю и внутреннюю репутацию, характерные особенности деятельности;

2) разработка стратегии. После анализа ситуации нужно выявить цели, задачи, сроки и средства для создания желаемого образа;

3) сама реализация стратегии и мониторинг информации.

Следовательно, чтобы создать нужный имидж для администрации, необходимо решить определенные задачи, которые предполагают целенаправленное формирование благоприятного восприятия местных органов власти в сознании жителей муниципалитета. Ерыкалова Ю. О. выделяет следующие задачи, во-первых, нужно определить цели, роли и стратегии развития учреждения. Затем провести работу со СМИ об информировании населения о планах и результатах действий администрации. В-третьих, обеспечить рост уровня доверия и авторитета к муниципальной администрации со стороны жителей, также обеспечить информационную связь, чтобы сформировать или изменить представление у масс об администрации муниципалитета.

Более конкретно этапы построения имиджа организации рассматривают Л. Калашникова и Г. Музлова, исследование которых основывается на американском опыте мастер планирования. Данный мастер-план имиджа состоит из четырех частей: создание фундамента, внешнего имиджа, внутреннего имиджа и неосязаемого имиджа.

Создание и сохранение благоприятного имиджа учреждения и организации зависит от того, насколько прочен построенный фундамент. Он состоит из нескольких шагов: во-первых, проведение ревизии деловых принципов, которые определяют разработку целей; во-вторых, создание идеологии фирмы или учреждения; в-третьих, выявление долгосрочных задач; и, наконец, формулировка определенных стандартов и правил деятельности сотрудников.

Вторая часть мастер-плана - это внешний имидж - то есть то, как общество, СМИ, инвесторы воспринимают учреждение. Внешний имидж формируется с помощью: улучшения качества услуги, осязаемого имиджа, связей со средствами массовой 
информации, рекламы, общественной деятельности, связей с инвесторами и, конечно, отношения сотрудников к работе и его внешнего вида.

Более детально внешний имидж администрации рассматривает Вольдман Л. Ю., в своей работе он разграничивает внешний имидж на поведенческие образы - поведение персонала на рабочем месте, поведение, которое проявляется во взаимодействии «руководитель - руководитель», «руководитель - подчиненный» и «подчиненный подчиненный», на корпоративную идентичность, т.е. фирменный стиль и деятельность учреждения как единого целостного.

Следующая часть - это внутренний имидж. Л. Калашникова и Г. Музлова определяют его как отношение сотрудников и руководителей к учреждению или организации. Другими словами, это атмосфера, складывающаяся внутри предприятия, отношение персонала к руководителям, которое может быть как позитивным и негативным, а также к политике учреждения. То, как население будет воспринимать администрацию, также зависит от внутреннего имиджа. Он создается посредством кадровой политики учреждения, программ поощрения персонала, тренингов сотрудников и финансового планирования.

Неосязаемый имидж - это эмоциональный настрой сотрудников и их отношение к работе. Аспекты неосязаемого имиджа также влияют на репутацию администрации, как и видимые или осязаемые элементы имиджа.

Чтобы сформировать положительный имидж в средствах массовой информации, используются средства создания имиджа. Самые распространенные инструменты описал Г.Г. Почепцов. В своей работе он приводит методы, которые можно применять в муниципальном управлении. Мифологизация - это подстройка под уже имеющийся миф в массовом сознании. Например, наиболее часто используются следующие мифы: исторические мифы (роль личности и народа в истории); государственные мифы (администрация муниципалитета отвечает за всю свою территорию); управленческие мифы (руководитель всегда прав) и пр.

Эмоционализация - это перенаправление сообщения на язык и цели населения. Эмоции проникают в сообщение по следующим путям: сопереживание, как подстраивание под чужую эмоцию, заимствование чужих эмоций - это ссылка на то, чтобы сделать их своими, конкретизация - рассказ об определенном предмете, который может стать источником эмоций.

Способ, который помогает оградить имидж от отрицательных ассоциаций дистанцирование. Это перекладывание ответственности за нежелательные последствия на обстоятельства, которые нельзя предвидеть, например, деловой климат в районе, непрофессиональных исполнителей и т.д.

Самое распространённое средство формирования имиджа - манипулирование. Оно заключается в переносе внимания на какой-либо другой предмет. Чаще всего необычность этого предмета затмевает актуальный объект и отвлекает человека от действительно важной информации.

Акцентирование информации. Сюда входит выпячивание информации, а также ее утаивание. Средства массовой информации отбирают ту или иную информацию, а технология отбора определяется ценностными критериями, которые не являются объективными. Большое значение имеет результат этого метода. Он может быть как формирование положительной информации о себе, с одной стороны, а с другой, это порождение негативной информации о своих врагах. Например, выгодное освещение работы государственных структур или умалчивание каких-то фактов, которые могли бы вызвать отрицательную реакцию у населения.

Очень часто используют такой метод, как опрос общественного мнения. Он выступает как инструмент воздействия, который формирует общественное мнение, так и элемент анализа. Опрос граждан рассматривается в Федеральном законе «Об общих принципах организации местного самоуправления в Российской Федерации» как одна из форм участия граждан. Данный закон усиливает действие опроса в качестве средства формирования имиджа, так как итоги исследования имеют рекомендательный характер.

Итак, формирование имиджа администрации - это процесс, который включает в себя следующие этапы: 
- оценка желаемого имиджа;

- создание программы выстраивания идеального имиджа;

- реализация программы;

- мониторинг нового имиджа.

Формирование имиджа администрации основано на его структуре. Поэтому улучшение и развитие каждой составляющей имиджа будет направлено на построение положительного имиджа. Важной частью имиджа учреждения является стиль деловых отношений.

В процессе построения имиджа используются различные средства, инструменты и методы, которые лежат в основе психологических методов воздействия на аудиторию.

$$
* * *
$$

1. Абенова Э. И. Понятие, сущность и средства формирования имиджа // Материалы сборника трудов XIV Международной научно-практической конференции. студентов и аспирантов «Творчество молодых: дизайн, реклама, информационные технологии». - Омск: Изд-во «ОмГТУ», 2015. - С. 75 79.

2. Вольдман Л. Ю. Имидж организации и механизм его формирования // Высшее образование сегодня. 2014. - № 4. - С. 14-18.

3. Гордеева О.В. Имидж предприятия сферы услуг: понятие и классификация // Экономика и управление: Новые вызовы и перспективы. - Тольятти: Изд-во «ПВГУС», 2013. - № 5. - С. 93-96.

4. Ерыкалова Ю. О. Формирование позитивного имиджа администрации муниципального образования // Материалы XX Всероссийского экономического форума молодых ученых и студентов. Конкурентоспособность территорий. - Екатеринбург: Изд-во «УралГЭУ», 2017. - С.123-124.

5. Калашникова Л., Музлова Г. Формирование имиджа: Этот процесс начинается с планирования работы с персоналом // Служба кадров. - 2014. - №10. - С. 25-29.

6. Об общих принципах организации местного самоуправления в Российской Федерации: закон РФ от 06.10.2003 N 131-Ф3 (ред. от 29.12.2017) // КонсультантПлюс- Режим доступа: http://www.consultant.ru/document/cons_doc_LAW_44571/(дата обращения 01.04.2018).

7. Почепцов, Г. Г. Имиджелогия. - - М :Иззд-во «Реффл-бук, Ваклер», 2001. — 704 с.

8. Русаков А.Ю. Связи с общественностью в органах государственной власти. - СПб: Из-во Михайлова B.A., 2006. -224 c.

Попова Е.В., Брюхнова А.В. Феминизм в рекламе

Рязанский государственный университет имени С.А. Есенина (Россия, Рязань)

doi: $10.18411 / \mathrm{lj}-08-2018-33$

idsp: 000001:lj-08-2018-33

\section{Аннотация}

Идеи феминизма широко распространены во всем мире. Феминистское движение зародилось в США, накладывая отпечаток на разные сферы общественной жизни, в том числе на рекламу. Образы женщин в рекламе претерпевали разные изменения, то их лишали женственности, то вновь возвращали. Сейчас ролики о правах женщин получают призы престижных кинофестивалей, привлекая к себе внимание. Рекламный продукт, содержащий идеи феминизма, пользуется большим спросом в западных странах, чем в нашей стране.

Ключевые слова: феминизм, массовая культура, реклама, рекламный ролик.

Феминистское движение появилось в Соединенных Штатах Америки в 1960-70-х годах. Именно там оно достигло наивысшего развития, доходившего иногда до абсурда. Это движение оказало влияние на массовую культуру, в том числе и на рекламу. Наиболее ортодоксальные представители феминизма выступали против любых проявлений женственности в рекламе, считая их дискриминацией женщин. В результате в 
рекламе того времени перестали демонстрировать образы женщин матери или домохозяйки.

В европейских странах феминизм не принял таких крайних форм, поэтому его влияние в рекламе было слабее, чем в США.

Восьмидесятые годы прошлого столетия стали периодом серьёзного переосмысления взаимоотношений полов в США. Теперь представительницы слабого пола стали изображаться не только успешными, умными, независимыми, но и женственными, также вернулись образы женщин-матерей и женщин-домохозяек.

В США в начале 1990-х впервые на женщин стала позиционироваться реклама изначально мужских товаров: спортивная обувь, сигареты, пиво.

К началу XXI века большинство мужчин и женщин обнаружили сильную потребность в сохранении и акцентировании гендерных отличий.

Женщины в XXI веке представляют собой серьезную силу, о чем свидетельствует тот факт, что они занимают ключевые должности в современных государствах. Идеи равноправия широко распространены на Западе и перемещаются на Восток. В этих тенденциях большую роль играет массовая культура.

Обратим наше внимание на главных героев известного сериала «Игра престолов». Это женщины. Компания «Disney» снимает самые кассовые мультфильмы про самостоятельных и решительных принцесс, например, «Храбрая сердцем», «Холодное сердце». Недавний хит от студии - производственная драма «Зверополис» о вымышленном городе, населённом антропоморфными зверями. Главная героиня Джуди - первый в истории заяц-полицейский, ей приходится столкнуться с серьезной дискриминацией, но в итоге она сможет доказать, что достойна носить золотой значок.

Маркетологи так же как сценаристы и продюсеры понимают, за какую аудиторию им нужно бороться. Идеи феминизма и эмансипации активно используются рекламистами и креативными агентствами в разных странах.

Пионером в создании профеминистских роликов стал транснациональный холдинг «Unilever», запустивший для своего бренда «Dove» соответствующую рекламную кампанию десять лет назад. Лицами кампании стали девушки немодельной внешности, которые снимались в рекламе практически без макияжа. Кампания имела большой успех, о чем говорят цифры. Продажи товаров выросли на $600 \%$ в США и на $700 \%$ в Европе за два месяца. Новаторство рекламы заключалось в отсутствии объективации (опредметнение) в роликах, а не в продвижении идей феминизма. Девушки, снявшиеся в ролике, отличались от моделей, которые обычно рекламировали косметику. Появление девушек в рекламе без косметики выглядело провокацией.

Первым брендом, который сделал откровенно профеминистскую рекламу, был «Pantene» компании «Procter \& Gamble» (P\&G). Ролики с названием «Labels Against Women» («Ярлыки против женщин») вызвали поддержку со стороны женщин, отстаивающих идеи равноправия, и обсуждения в соцсетях, которые привлекли внимание к кампании. Тем не менее, ролики лишь констатировали наличие стереотипов, но не призывали изменить их.

В мире бренды целенаправленно используют профеминистские идеи для рекламы. В сентябре 2014 года немецкий модельер Карл Лагерфельд превратил показ осеннезимней коллекции в феминистский митинг, организовав показ мод на улице. Модели держали в руках мегафоны и плакаты, изображая активисток. Эффект от показа был колоссальный: он вызвал интерес не только у глянцевых журналов, но и общественнополитических изданий во всем мире. По итогам 2014 года три ролика о правах женщин одновременно получили призы Каннского кинофестиваля: ролик «Like a Girl» от бренда «Always», кампании против насилия в Турции и в поддержку женщин в Индии.

О равноправии говорят бывшая первая леди США Мишель Обама и известная актриса Эмма Уотсон, указывая на то, что равноправие влияет на экономику. Женщины 
считаются более активными потребителями по сравнению с мужчинами. Они отвечают за покупки по хозяйству, приобретение товаров для детей, как правило, они больше тратят на поддержание красоты и здоровья. Раньше маркетологи предпочитали обращаться к ним опосредованно, ведь женщины зарабатывали меньше мужчин, а теперь разница в доходах снижается. Женщины становятся более независимыми и состоятельными субъектами экономического рынка. Согласно исследованию McKinsey Global Institute, глобальная экономика недополучает \$28 трлн из-за проблем с равноправием - многие женщины не имеют возможности работать и зарабатывать, а также рассчитывать на адекватную оплату своего труда, а значит, не могут тратить деньги согласно своим потребностям. В результате, поддерживая феминистические идеи, можно поддержать мировую экономику.

У нашей страны свой путь в рассматриваемом вопросе. Согласно соцопросам «Левада-центра», 75\% женщин и 51\% мужчин поддерживают идеи равноправия. В общем, аудитория в стране настроена консервативно и не готова откликаться на прогрессивные идеи о самостоятельности женщины. Об этом свидетельствует провал русскоязычной версии ролика компании «Mattel», которая производит куклы Barbie. По сюжету маленькие девочки играют в куклы и мечтают о том, кем станут, когда вырастут. Среди них есть бизнес-леди, ветеринар, тренер футбольной команды и другие героини. В мире ролик набрал миллионы просмотров, в России - всего 350000.

В 2015 году спортивный бренд «Adidas», занимающий второе место по объёму продаж в мире заявил о смене стратегии. Впервые за свою историю бренд пригласил женщин для съемок ролика. Супермодель Карли Клосс, блогер и атлет Робин Арзон, диджей и дизайнер Ханна Бронфман не только занимаются спортом в рекламе «Adidas», но и готовят печенье, жарят осьминога, делают маникюр. Для России формат не стали адаптировать.

Бренд «Alaways» компании $\mathrm{P} \& \mathrm{G}$ одним из первых призвал бороться за права своих потребителей. В 2014 году вышел рекламный ролик, снятый американским режиссером Лорен Гринфилд по сценарию рекламного агентства «Leo Burnett». Бренд призвал девушек переосмыслить выражение «как девчонка». Ведь в спорте ударить хорошо означало «ударить по-мужски», а бить «как девчонка» означало ударить плохо. Эта кампания в мировых соцсетях имела большой успех - хештег \#likeagirl использовали миллионы блогеров.

«Для России ролик не переводили, он сопровождался субтитрами. Было предположено, что российское общество до такой кампании пока не дозрело». Тем не менее, видео собрало 3 млн просмотров в русскоязычном сегменте YouTube. Сотни тысяч пользователей опубликовали свои фотографии под запущенным эсэмэмщиками хештегом \#какдевчонка в соцсети «ВКонтакте».

В результате маркетологи «Always» использовали интерес россиян к женскому вопросу и сняли ролики с российской певицей Юлианной Карауловой, призывающей зрительниц на её концерте показать свой талант и не упустить свой шанс. Итоги кампании оказались провальными: три ролика просмотрело меньше 30000 пользователей YouTube. Бренд не решился выйти за рамки стереотипов и использовать более смелое послание.

В России женщины стремятся к независимости и соблюдению своих прав, но не ассоциируют это с феминизмом, который ошибочно считается чем-то маргинальным и радикальным. Интересно, что согласно опросам «Левада-центра» участие женщин в политике одобряют 66\% опрошенных мужчин и $86 \%$ опрошенных женщин. Однако, если задать женщинам вопрос, разделяют ли они идеи феминизма, скорее всего, ответ будет отрицательным, а если спросить, должны ли женщины и мужчины за одинаково выполненную работу получать одинаковые деньги, конечно, все скажут "да""', — считает Ольга Страховская, главный редактор издания Wonderzine. 
«В Москве образы феминисток слишком маргинализированы, и клиенты не соглашаются на идеи, в которых есть образы борьбы за женские права», - подтверждает представитель креативного агентства «Восход» Ирина Клепикова.

Для того чтобы делать некий массовый «феминистский» продукт в России, необходимо отказаться от калькирования западных образцов. Собственные образцы здесь пока не выработаны.

Про Россию нельзя сказать, что в ней совсем отсутствует феминистское движение и феминистская мысль. Однако все представления об этом направлении разрозненны и разобщены.

Несмотря на осторожность маркетологов и общую консервативность аудитории, Россия всё же развивается в рамках мирового тренда. Вопрос о разнице уровня доходов уже поднимается в деловой прессе, женщины стремятся построить карьеру и получить финансовую независимость. В социальных сетях поднимаются стигматизированные ранее темы, связанные с высоким уровнем насилия в обществе по отношению к женщинам. Не исключено, что мы увидим больше рекламных кампаний, призывающих быть собой.

$$
* * *
$$

1. Женщина и визуальные знаки / под ред. А. Альчук. - М.: Идея-Пресс, 2000. -280 с.

2. Кафтанджиев Х. Герои и красавицы в рекламе в рекламе. - СПб.: Питер-холдинг, $2008-223$ с.

3. Кафтанджиев Х. Образ женщины в рекламе. - М.: РИП-холдинг, $2007-225$ с.

4. https://secretmag.ru/trends/tendencies/feminizm-kak-dvigatel-torgovli.htm

5. https://retailer.ru/novoe-v-reklame/

6. http://denis-zuev.ru/marketing-articles/45-psikhologiya-reklamy

7. http://lichnosteto.ru/item/reklama-lichnosti-eto

8. https://daily.afisha.ru/relationship/4661-eto-feminizm-ili-marketing-anna-narinskaya-o-reklame-s-blagiminamereniyami/ 


\title{
РАЗДЕЛ IV. МЕНЕДЖМЕНТ
}

\author{
Амурская О.И., Муравьева А.В. \\ Значимость бренда в сфере образовательных услуг \\ Рязанский государственный университет имени С.А. Есенина
}

(Россия, Рязань)

doi: $10.18411 / \mathrm{j}-08-2018-34$

idsp: 000001:lj-08-2018-34

\section{Аннотация}

В статье рассматриваются вопросы формирования сильного бренда и его влияния в сфере образовательных услуг. Даны характеристики стадий организации бренда образовательного учреждения, а также сделан вывод о том, что наличие бренда является важным конкурентным преимуществом для любого образовательного учреждения, позволяющим укрепить рыночные позиции учреждения.

Ключевые слова: бренд, реклама образовательного учреждения, позиционирование, управлением брендом, продвижение бренда

В настоящее время значительно возрастает спрос на образовательные услуги, в связи с этим образование становится все более перспективной и глобальной областью экономики. Система высшего образования прогрессирует наиболее активно. Университеты познают на себе воздействие рыночных отношений, изменения образовательной политики и образовательных стандартов. Так как мировой рынок в сфере высшего образования сформировывается усиленно, и это приводит к конкурентной борьбе за абитуриентов. В связи с этим, активно развивается брендинг в сфере образовательных услуг. Брендинг по отношению к образовательному учреждению понимается как «управленческий процесс, направленный на развитие у него особых материальных и нематериальных характеристик, которые позволяют выделиться в ряду конкурентов, быть уникальным».

Разница, отличающая брендинг услуг от брендинга товаров, обусловлена своеобразностью самих услуг, таких свойств, как неосязаемость, нематериальность, невозможность хранения и др. В связи с этим, брендинг в сфере образовательных услуг определяется как комплекс приемов и способов, с помощью которых до потребителя образовательных услуг доводится сформированный бренд вуза и его исключительные свойства. В этом контексте бренд университета - ожидание потребителями образовательных услуг приобретения определенной пользы в результате обучения по конкретной специальности. Также бренд университета содействует удовлетворению потребности в образовании.

Процесс организации бренда образовательного учреждения состоит из следующих стадий:

1. Позиционирование. Данный период представляет собой процесс перенесения бренда образовательного учреждения в сознание потребителей. При этом важными компонентами могут быть: доверие (соотношение ожиданий потребителей и настоящим положением учреждения), ценность (воспринимаемая польза для потребителей) и пригодность (приоритетные стороны образовательного учреждения).

2. Формирование особенностей бренда. К ним можно отнести миссию, ценности, философию, корпоративную культуру, имидж и т.д. 
3. Разработка атрибутов бренда. Атрибуты бренда - единый фирменный стиль и сайт, история. Грамотно представленные атрибуты облегчают формирование корпоративной культуры данного бренда исодействуют его конкурентоспособности.

4. Управление брендом. Грамотный бренд - менеджмент в образовательной среде содействует позиционированию в глазах потребителей благоприятного мнения о данном бренде. Но чтобы бренд образовательного учреждения завоевал известность и признание потребителей, нужны значительные капиталовложения и ощутимый период времени.

5. Продвижение бренда. Данный этап осуществляется с помощью выбора определенного канала коммуникации и методов продвижения. Основная особенность продвижения образовательного учреждения - единовременная работа на двух рынках образовательных услуг (образовательные программы) и труда (квалифицированные выпускники). Поэтому возникает необходимость в продвижении не только образовательных программ, но и выпускников.

Образование бренда образовательного учреждения наступает с момента его выхода на рынок, а его развитие представляет собой непрерывный процесс.Образ вуза основывается на представлении о нем различных целевых аудиторий. Всеми составляющимиобраза (местоположение, название, миссия, фирменный стиль, логотип, история, легенды, сайт и другие атрибуты) нужно пользоваться так, чтобы университете был привлекательным, заинтересовывал целевые группы. Поэтому университет постоянно должен поддерживать свой имидж в глазах общественности.

Понятие «бренд образовательного учреждения» включает в себя:

- само образовательное учреждение

- собрание характеристик, ожиданий, ассоциаций, осознаваемых потребителем и приписываемых образовательному учреждению;

- информацию о потребителях;

- обещания каких-нибудь достижений, дающихся образовательным учреждением потребителям.

Именно вследствие грамотной разработки бренда и четкого управления им обеспечиваются следующие положительные результаты:

- уменьшение затрат на продвижение бренда;

- защита от деятельности конкурентов;

- увеличение лояльности потребителей;

- юридическая защита исключительных атрибутов образовательной организации;

- укрепление корпоративной культуры и т.д.

Корпоративная культура играет весьма большое значение в формировании бренда образовательного учреждения. Она благоприятствует развитию самосознания, формирует ответственность работников, создает ощущение надежности и стабильности организации.

Таким образом, можно сделать вывод, что бренд является важным конкурентным преимуществом для любого образовательного учреждения. С его помощью происходит увеличение рыночных позиций учреждения, легко вводятся на рынок новые виды образовательных услуг и интеллектуальные продукты. Для образовательного заведения наиболее приоритетным являются достижение крепкой и стабильной позиции на рынке образовательных услуг, производство современных и актуальных направлений образовательной и научной деятельности, увеличение количества предоставляемых услуг. 
Решить данные задачи возможно только при наличии сильного и конкурентоспособного бренда.

1. Балабанова В. В. Развитие и поддержка ценности бренда с сфере образовательных услуг // Вестник ТГУ. - 2009. - №328. - с. 122-125.

2. Грошев И. В., Юрьев В. М. Вуз как объект брендинга// Высшее образование в России. - 2010. - № 1. c. $25-29$.

3. Даль В. Толковый словарь живого великорусского языка: В 4 т. Т. 4: C-V. М.: ОЛМА-ПРЕСС, 2001.$576 \mathrm{c.}$

4. Лухменева Е.П., Калиева О.М. Особенности формирования и продвижения бренда вуза // Вестник ОГУ. - 2012. - № 13. - С. 228- 231.

5. Хангельдиева И. Г. Бренд ВУЗа как его нематериальный ресурс и ключевой идентификатор // Культура и образование в современном обществе: стратегии развития и сохранения (сборник научных статей по материалам всероссийской научной конференции с международным участием. Ответственный редактор Т. В. Коваленко).- Краснодар: Издательство: ООО «Экоинвест». - 2013.- с. 59-77.

\section{Финашина Т.B. \\ Особенности маркетинговых мероприятий, направленных на улучшение имиджа учреждения культуры}

Президентская академия РАНХиГС

(Россия, Москва)

doi: $10.18411 / \mathrm{j}-08-2018-35$

idsp: 000001:lj-08-2018-35

\section{Аннотация}

Данная статья посвящена изучению особенностей маркетинговых мероприятий, направленных на улучшение имиджа учреждений культуры. В ходе написания работы бала определена актуальность рассматриваемого вопроса, исследованы взгляда различных авторов относительно данной тематики, выявлены основные особенности маркетинговой политики, реализуемой учреждениями культуры.

Ключевые слова: маркетинговая политика, учреждения культуры, целевая аудитория, реклама, продвижение.

Актуальность данной темы обусловлена тем, что маркетинг является одним из основных инструментов, способствующих успешному функционированию предприятий. Одна из главных задач маркетинговых мероприятий заключается в создании у клиентов положительного мнения относительно имиджа учреждения, что влечет за собой увеличение числа потребителей товаров и услуг предприятия. Маркетинговая политика учреждений культуры имеет ряд особенностей, обусловленных, в первую очередь, специфическими чертами основной деятельности рассматриваемых организаций.

На сегодняшний день данный вопрос является объектом изучения большого количества авторов. Так, Быстрова О.А. в своей работе рассматривает продвижение культурного продукта в системе маркетинга социально-культурной сферы, акцентируя свое внимание на основных средствах продвижения [2]. Булатова С.Н. и Слаутина Н.М. занимаются исследованием влияния маркетинговых инструментов на уровень конкурентоспособности учреждения социально-культурной сферы [1].

Имидж организаций культурной сферы имеет очень важную роль в благоприятном функционировании данных предприятий, поскольку деятельность большинства субъектов области культуры финансируется в основном за счет бюджетных средств, а положительный имидж учреждения способствует привлечению спонсоров [4]. Помимо 
этого, положительный имидж влечет за собой и привлечение потребителей культурных услуг.

Для положительных результатов использования имиджа, необходимо использование маркетинговых мероприятия, в частности, направленных на продвижение этого имиджа. В культурной среде маркетинговая политика имеет некоторые особенности, основными из которых являются [3]:

- Отсутствие конкретного продукта, в качестве которого выступают различные услуги. Основными услугами являются: развлекательные, которые реализуются в процессе показа спектаклей, концертов и других развлекательных мероприятий; образовательная, которая заключается в проведении экскурсий, лекций, конференций, семинаров; выставочная деятельность, социально ориентированная. Так же организации культурной сферы предоставляют своим клиентам и дополнительные услуги, которыми могут: работа в учреждении кафе, буфетов, сувенирных магазинов; возможность проведения приемов, встреч, концертов. Наличие дополнительных услуг значительно улучшает имидж учреждения культуры;

- Сложность в определении ключевого клиента. Данная особенность вызвана выше указанной специфической чертой учреждений культуры. Отсутствие конкретного продукта влечет за собой трудности в определении целевой аудитории;

- Неэффективность рекламы. Потребители, пользующиеся услугами учреждений культуры, предъявляют на них спрос практически на постоянной основе, то есть в независимости от разрекламированности продуктов предприятий, функционирующих в сфере культуры;

- Низкая степень использования инновационных технологий с целью улучшения имиджа учреждения культуры. Нововведения организациями культуры используются крайне редко, так как основной продукт не подразумевает их применения. К примеру, показ спектаклей не требует применения инноваций.

Подводя итог, можно сделать вывод, что особенности элементов маркетинговой политики учреждений культуры вызваны чертами, характерными конкретно области культуры, которые препятствуют реализации маркетинговой политики в полной мере. Особенно это касается мероприятий, направленных на продвижение услуг, предоставляемых предприятиями, функционирующими в сфере культуры. Следовательно, отсутствует результат, заключающийся в улучшении имиджа учреждений культуры, на основании чего можно сказать, что имидж культурного учреждения - это созданный на протяжении некоторого периода образ, составленный из элементов, относящихся, в частности, к качественным характеристикам самого учреждения.

$$
\text { *** }
$$

1. Булатова С. Н., Слаутина Н. М. Повышение уровня конкурентоспособности учреждений клубного типа социально-культурной сферы // Вестник Кемеровского государственного университета культуры и искусств. 2016. №29-2. URL: https://cyberleninka.ru/article/n/povyshenie-urovnya-konkurentosposobnostiuchrezhdeniy-klubnogo-tipa-sotsialno-kulturnoy-sfery (дата обращения: 20.07.2018).

2. Быстрова О. А. Продвижение культурного продукта в системе маркетинга социально-культурной сферы // Аналитика культурологии. 2015. №27. URL: https://cyberleninka.ru/article/n/prodvizheniekulturnogo-produkta-v-sisteme-marketinga-sotsialno-kulturnoy-sfery (дата обращения: 20.07.2018).

3. Канащук Т. Н. Эффективность маркетинга учреждений культуры // OHB. 2016. №5 (112). URL: https://cyberleninka.ru/article/n/effektivnost-marketinga-uchrezhdeniy-kultury (дата обращения: 20.07.2018).

4. Новаторов Э. В. Концепция маркетинга услуг учреждений культуры // Вестник МГУКИ. 2015. №6. URL: https://cyberleninka.ru/article/n/kontseptsiya-marketinga-uslug-uchrezhdeniy-kultury (дата обращения: 20.07.2018). 


\title{
РАЗДЕЛ V. ЭКОНОМИКА
}

\author{
Батаев A.B. \\ Анализ мирового рынка добычи нефти \\ Санкт-Петербургский политехнический университет Петра Великого \\ (Россия, Санкт-Петербург)
}

doi: $10.18411 / \mathrm{lj}-08-2018-36$

idsp: 000001:lj-08-2018-36

\section{Аннотация}

В статье проводится исследование мирового рынка нефтедобычи, выявляются ключевые игроки, определены основные тенденции на рынке по добыче нефти, на основе проведенного анализа делаются прогнозы на дальнейшее развитие рынка по нефтедобыче.

Ключевые слова: рынок по добыче нефти, структура рынка, лидеры по нефтедобыче, перспективы развития.

В современном мире нефть и газ являются ключевыми продуктами для развития всей мировой экономики. Страны богатые этими природными ископаемыми оказывают огромное влияние на все экономическое развитие. Сегодня без углеводородного сырья невозможно развитие практически ни одной современной отрасли промышленности.

В последние несколько лет цена на черное золото не является стабильной. Если еще несколько лет назад до 2008 года на рынке нефтедобычи присутствовал только один тренд на удорожание нефти, то в последние годы после падения цены нефти с рекордных 149 долларов за баррель до 40 долларов, наблюдается разнонаправленные тренды как на повышение, так и на понижение цены на нефть.

Сегодня на мировом рынке добычи нефти присутствуют три ключевых игрока, которые и определяют тренды на развитие современного рынка нефтедобычи. В последний год лидером по добыче нефти являлась Российская Федерация, которая нарастила добычу нефти до показателя в 10,3 миллиона баррелей в сутки, но в марте 2018 года на первое место по нефтедобыче вышли США, которые нарастили добычу нефти до величины 10,43 миллиона баррелей нефти в сутки, обогнав Российскую Федерацию. На третьем месте находится Саудовская Аравия с показателем в 9,93 миллиона баррелей в сутки (рис. 1). [1-5]

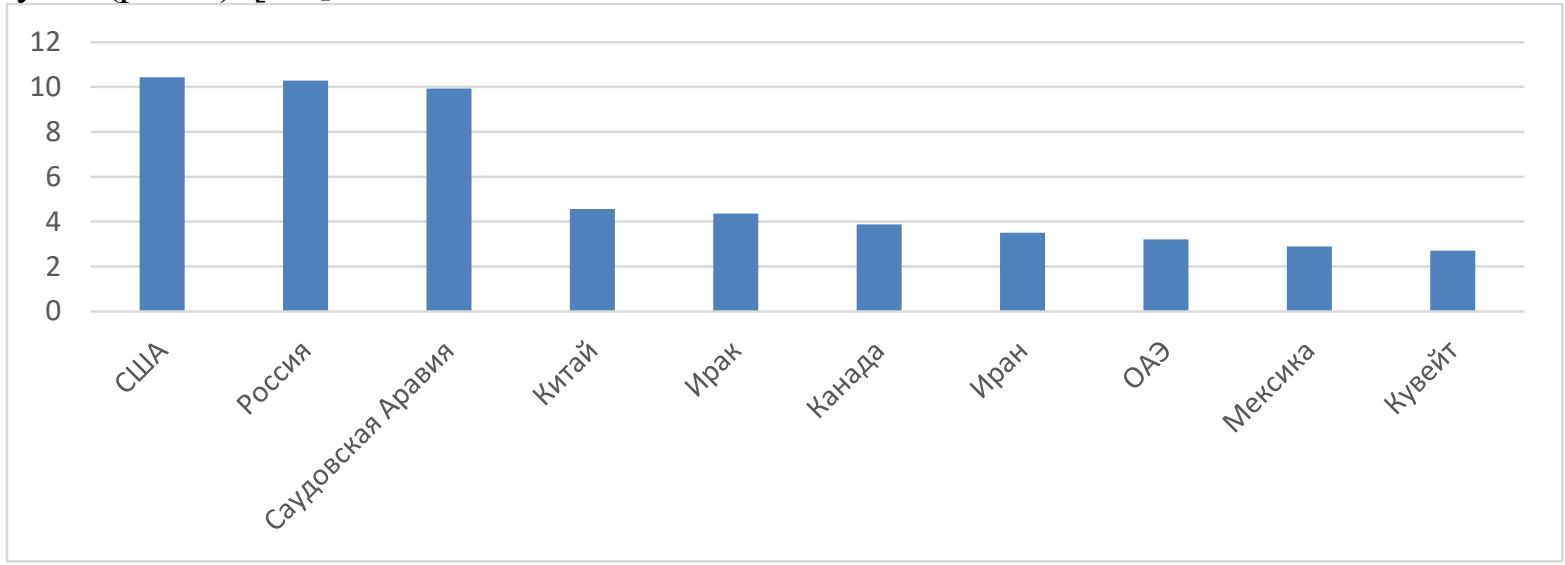

Рис. 1 Мировые лидеры по нефтедобыче, миллионов баррелей в сутки.

На долю трех крупнейших игроков: США, Российской Федерации и Саудовской Аравии приходится свыше $30 \%$ всей мировой добычи нефти. Именно эти три страны и 
определяют каким будет цена на черное золото в мире. При этом стоит отметить, что в дальнейшем лидерство США будет укрепляться. К 2020 году в планах этой страны увеличить нефтедобычу до 12 миллионов баррелей в сутки, что должно обеспечить ее бесспорное лидерство. [4, 5]

На современном нефтяном рынке существует две противоположные тенденции: с одной стороны, существует союз стран ОПЕК и России, которые ограничивают добычу нефти и стремятся увеличить стоимость черного золота, с другой стороны США, Канада и другие страны, которые наращивают добычу нефти и стремятся снизить стоимость нефти. Следует отметить, что наращивание нефтедобычи США привело к тому, что Россия и Саудовская Аравия призвали страны ОПЕК увеличить квоты на добычу нефти, чтобы не потерять традиционные для них рынки, которые могут переориентироваться на других ключевых игроков нефтяного рынка.

В заключении можно сделать следующие выводы:

в последние несколько лет мировой рынок нефтедобычи не отличается стабильностью, цена нефти имеет тренды как на ее повышение, так и на ее понижение, такие разнонаправленные тенденции обусловлены появлением нового ключевого игрока на рынке нефтедобычи, а именно США, которые за несколько лет смогли обеспечить лидерство по добыче нефти с показателем в 10,43 миллиона баррелей в сутки;

дальнейшее наращивание добычи нефти США, Канадой заставляет такие страны, как Российская Федерация и страны ОПЕК также поднимать уровень добычи нефти, чтобы не потерять свою долю на нефтяном рынке, повышение уровня нефтедобычи в последующие годы приведет к снижению стоимости черного золота и фиксации его на уровне комфортном для США и стран, поддерживающих тренд на снижение стоимости нефти.

$$
* * *
$$

1. Объём добычи нефти стран лидеров. [Электронный pecypc]. https://neftok.ru/dobycha-razvedka/obemdobychi-nefti.html (Дата обращения: 30.07.2018).

2. Россия в марте уступила мировое лидерство по добыче нефти США. [Электронный ресурс]. https://ria.ru/economy/20180517/1520778523.html (Дата обращения: 30.07.2018).

3. Раздел добычи: ОПЕК разрывает изнутри. [Электронный ресурс]. https://www.gazeta.ru/business/2018/06/19/11807047.shtml (Дата обращения: 30.07.2018).

4. Запасы нефти по странам мира в 2018 году. [Электронный pecypc]. http://bslife.ru/makroekonomika/zapasy-nefti2017.html (Дата обращения: 30.07.2018).

5. Америка догоняет Россию по добыче нефти. [Электронный ресурс]. https://lenta.ru/articles/2018/02/04/usoiloutput/ (Дата обращения: 30.07.2018).

\section{Граница Ю.В.}

\section{Аудиторский контроль соблюдения требований федеральных государственных стандартов образовательными организациями}

Национальный исследовательский Нижегородский государственный университет им. Н.И. Лобачевского

doi: $10.18411 / \mathrm{j}-08-2018-37$

(Россия, Нижний Новгород)

idsp: 000001:lj-08-2018-37

\section{Аннотация}

Контроль за реализацией образовательных программ учебными заведениями и оценка соблюдения требований федеральных государственных образовательных стандартов необходимы и обеспечивают конкурентоспособность реализуемых образовательных продуктов на рынке.

Считаем, что методика проверки качества оказания услуг в сфере образования не должна принципиально отличаться от иных видов контрольных мероприятий в других 
областях деятельности. В 2017 году обновлены стандарты осуществления аудиторского контроля с учетом требований международной практики. Применение международных стандартов аудита в сфере образования рассмотрим в данной статье.

Ключевые слова. Образовательный стандарт, образовательная программа, задание по оказанию услуг, обеспечивающих уверенность, аккредитация образовательной деятельности.

На сегодняшний день все образовательные организации должны проходить процедуру государственной аккредитации образовательных программ в соответствии с требованиями Ф3 №273-Ф3 «Об образовании в Российской Федерации» [1]. Существует достаточное количество законодательных и нормативных актов, регулирующих процесс проведения государственной аккредитации, специалисты анализируют разные аспекты ее проведения [2], [3].

Экспертное сообществе выражает мнение, что государственная аккредитация является неэффективной контрольной процедурой и должна быть по примеру европейских стран заменена общественной аккредитацией, целью которой является выявление «узких мест» и разработка мер по повышению эффективности в деятельности организаций образовательной сферы.

Несмотря на то, что оба вида аккредитации образовательной деятельности предусмотрены законодательно, не существует утвержденных методик их проведения, что приводит к зависимости процесса экспертизы образовательной деятельности от профессионального суждения группы экспертов, проводящих проверку.

Обратимся к регулятивам, на основании которых осуществляется контроль в других областях деятельности. Считаем, что внимания заслуживают стандарты регулирующие деятельность аудиторских организаций.

С 2017 года профессиональное аудиторское сообщество было вынуждено отказаться от применения национальных стандартов и руководствоваться требованиями международных документов Законодатели это решение объясняли наличием устоявшейся системы международных регулятивов с богатой применительной практикой, которую можно перенять в полном объеме без каких-либо корректировок. Таким образом, были утверждены следующие группы стандартов:

- стандарты аудита;

- стандарты оказания сопутствующих аудиту услуг;

- стандарты по обзору финансовой информации;

- стандарты заданий, обеспечивающих уверенность, отличные от аудита и обзора.

Последняя группа документов является для российского аудиторского сообщества принципиально новой, не имеющей аналогов за всю история развития рынка аудиторских услуг, так как предметом проверки здесь не является бухгалтерская отчетность или же какая-либо иная аналогичная информация.

Общие принципы оказания услуг, обеспечивающих уверенность, содержатся в МСЗОУ 3000 «Задания, обеспечивающие уверенность, отличные от аудита и обзорной проверки финансовой информации прошедших периодов» [4].

Характеристика таких заданий представлена в таблице 1

Таблицุа 1

Характеристика заданий, обеспечивающих уверенность

\begin{tabular}{|c|c|}
\hline Элементы заданий & Характеристика элементов \\
\hline Трёхсторонние отношения & $\begin{array}{c}\text { Практикующий специалист, ответственная сторона, } \\
\text { предполагаемые пользователи (неограниченный перечень) }\end{array}$ \\
\hline Оцениваемый предмет задания & $\begin{array}{c}\text { Системы и процессы (например, система внутреннего } \\
\text { контроля или ИТ-система организации), в отношении которых } \\
\text { информацией о предмете задания может являться заявление }\end{array}$ \\
\hline
\end{tabular}




\begin{tabular}{|c|c|}
\hline & $\begin{array}{c}\text { об их эффективности; } \\
\text { организация работы (например, корпоративное управление, } \\
\text { соблюдение нормативных требований, практика работы с } \\
\text { кадровыми ресурсами), в отношении которых информацией о } \\
\text { предмете задания может являться заявление о соблюдении } \\
\text { установленных требований или заявление об эффективности. }\end{array}$ \\
\hline $\begin{array}{c}\text { Критерии оценки предмета } \\
\text { проверки }\end{array}$ & $\begin{array}{c}\text { Критерии, которые практикующий специалист ожидает } \\
\text { применить к подготовке информации о предмете задания, } \\
\text { должны быть доступны для предполагаемых пользователей }\end{array}$ \\
\hline Доказательства & Источники, позволяющие \\
\hline Отчет по заданию & $\begin{array}{c}\text { Документ, содержащий выводы о результатах оценивания } \\
\text { предмета задания }\end{array}$ \\
\hline
\end{tabular}

Проанализируем осуществляемый на сегодняшний день процесс аккредитации по указанным в МСЗОУ 3000 критериям

Таблица 2

Характеристика процедуры государственной аккредитациии аккредитации

\begin{tabular}{|c|c|}
\hline Элементы задания & $\begin{array}{c}\text { Анализ задания по проверке соответствия образовательной деятельности } \\
\text { требованиям федеральных государственных образовательных стандартов } \\
\text { (ФГОС) }\end{array}$ \\
\hline $\begin{array}{l}\text { Трёхсторонние } \\
\text { отношения }\end{array}$ & $\begin{array}{c}\text { Государственный орган, осуществляющий проверку, образовательная } \\
\text { организация, пользователи }\end{array}$ \\
\hline $\begin{array}{c}\text { Оцениваемый } \\
\text { предмет задания }\end{array}$ & $\begin{array}{c}\text { Подтверждение соответствия федеральным государственным } \\
\text { образовательным стандартам образовательной деятельности по основным } \\
\text { образовательным программам и подготовки обучающихся в образовательных } \\
\text { организациях, организациях, осуществляющих обучение }\end{array}$ \\
\hline $\begin{array}{c}\text { Критерии оценки } \\
\text { предмета проверки }\end{array}$ & Критерии определены во ФГОС ВО, ФГОС СПО \\
\hline Доказательства & $\begin{array}{c}\text { Перечень документов, предоставляемых для проведения аккредитационной } \\
\text { экспертизы }\end{array}$ \\
\hline Отчет по заданию & $\begin{array}{c}\text { Отчет эксперта по итогам проверки и характеристика образовательной } \\
\text { программы }\end{array}$ \\
\hline
\end{tabular}

Таким образом, очевидно что контрольная деятельность в сфере образования с легкостью укладывается в систему предложенных в аудиторском стандарте критериев. В чем же преимущества регулирования процесса экспертизы образовательных программ аудиторскими документами?

Во-первых, в международных аудиторских регулятивах, есть четко сфомулированные требования к оказанию услуг, а именно соблюдение этических принципов, содержащихся в кодексе этики и осуществление контроля качества выполнения задания в соответствии с требованиями МСКК 1 «Контроль качества в аудиторских организациях, проводящих аудит и обзорные проверки финансовой отчетности, а также выполняющих прочие задания, обеспечивающие уверенность, и задания по оказанию сопутствующих услуг» Во-вторых, процесс оказания услуг, обеспечивающих уверенность, представляет собой регламентированную последовательность этапов выполнения контрольных процедур, содержащихся в таблице 3

Таблийа 3

Этапы выполнения заданий, обеспечивающих уверенность

\begin{tabular}{|c|c|}
\hline Этап & Характеристика \\
\hline $\begin{array}{c}\text { Принятие клиента для } \\
\text { выполнения задания }\end{array}$ & $\begin{array}{c}\text { Анализ выполнения этических принципов по отношению к проверяемому } \\
\text { субъекту и оценка квалификации рабочей группы выполняющей задание }\end{array}$ \\
\hline Оценка риска & $\begin{array}{c}\text { Оценка риск того, что практикующий специалист представит ошибочный } \\
\text { вывод в тех случаях, когда информация о предмете задания содержит } \\
\text { существенные искажения. }\end{array}$ \\
\hline Оценка существенности & Определение наиболее значимых объектов проверки \\
\hline Определение характера, & Составление плана и программы проверки контрольных мероприятий, \\
\hline
\end{tabular}




\begin{tabular}{|c|c|}
\hline сроков и объема процедур & выбор достаточных и надлежащих доказательств \\
\hline $\begin{array}{c}\text { Оценка достаточности } \\
\text { полученных доказательств }\end{array}$ & $\begin{array}{c}\text { Оценка того, собрано ли достаточное количество надлежащих } \\
\text { докательств, а также того, следует ли предпринять дополнительные меры } \\
\text { для достижения целей задания, обеспечивающего уверенность }\end{array}$ \\
\hline Формирование отчета & $\begin{array}{c}\text { Отчет содержит выводы о соответчики предмета проверки установленным } \\
\text { критериям }\end{array}$ \\
\hline
\end{tabular}

Из таблицы 3 следует, что критерии для проверки образовательных программ четко определены, подлежат измерению или качественной оценки, то есть предмет проверки в полной мере соответствует требованиям МСЗОУ 3000.

Единственный возникающий при этом вопрос связан с отсутствием в аудиторских организациях квалифицированных специалистов в сфере образования, однако, МСЗОУ 3000 предусматривает включение в состав рабочей группы квалифицированных специалистов, обладающих компетенциями в различных областях.

Отличительной особенностью проведения экспертизы образовательных программ служат специфические для образовательной организации источники получения аудиторских доказательств, назначение которых должно быть пояснено привлекаемыми квалифицированными специалистами. Приведем перечень источников получения доказательств в ходе экспертизы образовательных программ (таблица 4)

Таблица 4

Источники получения доказательств

\begin{tabular}{|c|c|}
\hline Наименование источники & Назначение \\
\hline Учебный план & $\begin{array}{c}\text { Позволяет определить соответствие структуры } \\
\text { образовательной программы требованиям } \\
\text { федеральных государственных образовательных } \\
\text { стандартов в части наполнения видами учебной } \\
\text { нагрузки и объема времени, отводимого на } \\
\text { выполнение работ. } \\
\end{array}$ \\
\hline Календарный учебный график & $\begin{array}{c}\text { Позволяет определить объем времени, } \\
\text { предусмотренный для выполнения каждого вида } \\
\text { работ учебного плана }\end{array}$ \\
\hline $\begin{array}{c}\text { Рабочие программы дисциплин, практик, } \\
\text { государственной итоговой аттестации, } \\
\text { включающие фонды оценочных средств }\end{array}$ & $\begin{array}{c}\text { Определяют содержание учебных дисциплин, } \\
\text { практик, виды контроля }\end{array}$ \\
\hline $\begin{array}{c}\text { Расписание учебных занятий, промежуточной и } \\
\text { итоговой аттестации }\end{array}$ & $\begin{array}{c}\text { Позволяет установить время для проведения } \\
\text { учебных занятий, промежуточных и итоговых } \\
\text { аттестаций } \\
\end{array}$ \\
\hline Индивидуальные планы обучающихся & $\begin{array}{c}\text { Содержат виды учебной нагрузки и объем времени } \\
\text { необходимый для ее выполнения обучающимся по } \\
\text { индивидуальной образовательной траектории }\end{array}$ \\
\hline $\begin{array}{c}\text { Документы, содержащие информацию об } \\
\text { индивидуальном учете результатов освоения } \\
\text { обучающимися } \\
\end{array}$ & $\begin{array}{c}\text { Позволяют установить уровень освоения студентами } \\
\text { образовательной программы и уровень } \\
\text { сформированности компетенций }\end{array}$ \\
\hline Электронное портфолио обучающегося & $\begin{array}{c}\text { Свидетельствует о функционировании в } \\
\text { образовательной организации электронной } \\
\text { образовательной среды, в которой фиксируется } \\
\text { результаты обучения и оценка всех участников } \\
\text { образовательного процесса } \\
\end{array}$ \\
\hline $\begin{array}{c}\text { Документы и материалы о результатах научно- } \\
\text { исследовательской работы обучающихся }\end{array}$ & $\begin{array}{c}\text { Свидетельствуют о развитии компетенций в области } \\
\text { научно-исследовательской деятельности }\end{array}$ \\
\hline $\begin{array}{c}\text { Отчетность обучающихся по практикам, } \\
\text { оценочный материал и результаты аттестации по } \\
\text { практикам }\end{array}$ & $\begin{array}{c}\text { Доказывают освоение практических навыков } \\
\text { ведения деятельности }\end{array}$ \\
\hline Выпускные квалификационные работы & $\begin{array}{c}\text { Позволяют оценить итоговый уровень } \\
\text { сформированности компетенций }\end{array}$ \\
\hline $\begin{array}{c}\text { Протоколы заседаний государственной } \\
\text { экзаменационной комиссии }\end{array}$ & $\begin{array}{c}\text { Позволяет проверить процедуры проведения } \\
\text { итогового контроля освоения основной } \\
\text { образовательной программы }\end{array}$ \\
\hline $\begin{array}{c}\text { Отзывы руководителей выпускных } \\
\text { квалификационных работ о работе обучающихсs }\end{array}$ & $\begin{array}{l}\text { Содержат оценку обучающихся на завершающей } \\
\text { стадии участниками образовательного процесса }\end{array}$ \\
\hline
\end{tabular}




\begin{tabular}{|c|c|}
\hline $\begin{array}{c}\text { в период подготовки выпускной } \\
\text { квалификационной работы }\end{array}$ & \\
\hline $\begin{array}{c}\text { Договоры об организации и проведении практик, } \\
\text { заключенные между организацией, } \\
\text { осуществляющей образовательную деятельность, } \\
\text { и организациями, осуществляющими } \\
\text { деятельность по профилю, соответствующему } \\
\text { образовательной программе }\end{array}$ & $\begin{array}{c}\text { Свидетельствуют о сотрудничестве образовательной } \\
\text { организации с представителями работодателей }\end{array}$ \\
\hline $\begin{array}{c}\text { Штатное расписание, справки о кадровом } \\
\text { обеспечении основной образовательной } \\
\text { программы высшего образования } \\
\text { справка о работниках из числа руководителей и } \\
\text { работников организаций, деятельность которых } \\
\text { связана с направленностью (профилем) } \\
\text { реализуемой программы }\end{array}$ & $\begin{array}{c}\text { Являются свидетельством того, что образовательная } \\
\text { деятельность по программе осуществляется } \\
\text { квалифицированными научно-педагогическими } \\
\text { работниками о представителями профильных } \\
\text { организаций }\end{array}$ \\
\hline $\begin{array}{c}\text { Индивидуальные планы научно-педагогических } \\
\text { работников }\end{array}$ & $\begin{array}{c}\text { Определяют индивидуальную нагрузку } \\
\text { преподавателя и степень ее выполнения } \\
\end{array}$ \\
\hline Распорядительные акты & $\begin{array}{c}\text { Позволяют оценить движение контингента } \\
\text { обучающихся }\end{array}$ \\
\hline
\end{tabular}

Все проводимые контрольные мероприятия требуют документирования. Пример предлагаемого рабочего документ лица, проводящего проверку соответствия образовательной программы требованиям ФГОС представлен в таблице 5.

Таблиия 5

\section{Рабочий документ «Характеристика образовательных программ направления} подготовки 38.03.01 «Экономика»»

\begin{tabular}{|c|c|}
\hline Критерии оценки предмета задания & Содержание критериев \\
\hline Форма обучения & очная, заочная, очно-заочная \\
\hline Объем образовательной программы & 240 зачетных единиц \\
\hline Срок обучения & $\begin{array}{c}\text { в очной форме составляет } 4 \text { года, в очно-заочной форме } 4 \\
\text { года } 6 \text { месяцев, в заочной форме } 4 \text { года } 6 \text { месяцев лет. }\end{array}$ \\
\hline $\begin{array}{c}\text { Объем программы бакалавриата в очной } \\
\text { форме обучения, реализуемый за один } \\
\text { учебный }\end{array}$ & 60 зачетных единиц \\
\hline $\begin{array}{c}\text { Объем образовательных программ в очно- } \\
\text { заочной и заочной формах обучения по } \\
\text { индивидуальному учебному плану }\end{array}$ & не более 75 зачетных единиц в год \\
\hline $\begin{array}{c}\text { Количество часов, отведенных на занятия } \\
\text { лекционного типа в целом по Блоку } 1 \\
\text { «Дисциплины (модули)» }\end{array}$ & $\begin{array}{c}\text { не более } 50 \text { процентов от общего количества часов } \\
\text { аудиторных занятий, отведенных на реализацию этого } \\
\text { блока. }\end{array}$ \\
\hline Обеспеченность библиотечными фондами & $\begin{array}{c}\text { При реализации программ бакалавриата каждый } \\
\text { обучающийся в течение всего периода обучения обеспечен } \\
\text { индивидуальным неограниченным доступом к одной или } \\
\text { нескольким электронно-библиотечным системам } \\
\text { (электронным библиотекам) и к электронной } \\
\text { информационно-образовательной среде организации. } \\
\text { Электронно-библиотечная система (электронная } \\
\text { библиотека) и электронная информационно- } \\
\text { образовательная среда обеспечивает возможность доступа } \\
\text { обучающегося из любой точки, в которой имеется доступ к } \\
\text { информационно-телекоммуникационной сети «Интернет», } \\
\text { как на территории организации, так и вне ее. }\end{array}$ \\
\hline $\begin{array}{c}\text { Доля штатных научно-педагогических } \\
\text { работников }\end{array}$ & $\begin{array}{c}\text { не менее } 50 \text { процентов от общего количества научно- } \\
\text { педагогических работников организации. }\end{array}$ \\
\hline $\begin{array}{l}\text { Доля научно-педагогических работников, } \\
\text { имеющих образование, соответствующее } \\
\text { профилю преподаваемой дисциплины }\end{array}$ & не менее 70 процентов \\
\hline
\end{tabular}


Доля научно-педагогических работников, имеющих ученую степень и (или) ученое звание

Освоение компетенций не менее 70 процентов

все общекультурные и общепрофессиональные компетенции, а также профессиональные компетенции, отнесенные к тем видам профессиональной деятельности, на которые ориентирована образовательные программы, включаются в набор требуемых результатов освоения программы бакалавриата.

Итак, процесс экспертизы образовательных программ может осуществляться аудиторскими организациями, в которых существует годами отработанный механизм и методика проведения контрольных проверок. Поскольку аудиторские фирмы не выполняют административных функций и не уполномочены прекращать или приостанавливать деятельность образовательных организаций, а могут только выражать квалифицированное мнение о степени соответствия деятельности образовательной организации требованиям федеральных государственных образовательных стандартов, учитываемое пользователями образовательных услуг, результаты проверок будет являться основой для совершенствования образовательной деятельности и толчком для создания конкурентных преимуществ участников образовательного процесса.

$$
* * *
$$

1. Федеральный закон от 29.12.2012 N 273-Ф3 (ред. От 07.03.2018) «Об образовании в Российской

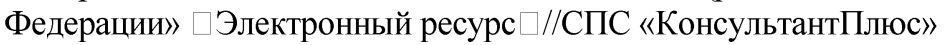

2. Лютоева Е.Н. Особенности аккредитации и лицензирования образовательной деятельности государственных вузов в правоприменительной деятельности Электронный ресурс $\square / /$ Вестник Коми республиканской академии государственной службы и управления. Серия: Государство и право. 2016. № 21. C. 120-123. https://elibrary.ru/item.asp?id=32351846

3. Додевич А.В. Государственная аккредитация образовательной деятельности $\square$ Электронный ресурс $\square / /$ Фундаментальные и прикладные исследования: проблемы и результаты. 2016. № 26-2. С. 135-140. https://elibrary.ru/item.asp?id=26104331

4. Международный стандарт заданий, обеспечивающих уверенность 3000 (пересмотренный) «Задания, обеспечивающие уверенность, отличные от аудита и обзорной проверки финансовой информации прошедших периодов» (введен в действие на территории Российской Федерации Приказом Минфина России от 24.10.2016 N 192н) $\square$ Электронный ресурс $\square / / С П С$ «Консультант Плюс»

5. «Международная концепция заданий, обеспечивающих уверенность $\square$ Электронный ресурс $\square / / \mathrm{URL}$ : http://minfin.ru

6. "Международный стандарт контроля качества 1 "Контроль качества в аудиторских организациях, проводящих аудит и обзорные проверки финансовой отчетности, а также выполняющих прочие задания, обеспечивающие уверенность, и задания по оказанию сопутствующих услуг" (введен в действие на территории Российской Федерации Приказом Минфина России от 24.10.2016 N 192н) Электронный ресурс $\square / / С П С$ «Консультант Плюс»

\section{Граница Ю.В. \\ Содержание научно-исследовательской работы обучающихся, освоивших образовательный блок дисциплин «Бухгалтерский учет» \\ Национальный исследовательский Нижегородский государственный университет им. Н.И. Лобачевского \\ (Россия, Нижний Новгород)}

doi: $10.18411 / \mathrm{j}-08-2018-38$

idsp: 000001:lj-08-2018-38

\section{Аннотация}

Традиционно образовательные организации выбирают для большей части гуманитарных направлений подготовки академический тип бакалавриата, где основным видом деятельности является - научно-исследовательская, аналитическая деятельность. 
Для формирования и закрепления навыков осуществления научноисследовательской деятельности предусмотрена научно-исследовательская работа. В статье предлагаются варианты выполнения самостоятельной научно-исследовательской работы

Ключевые слова: научно-исследовательская работа, научно-исследовательская деятельность, бакалавр экономики, профессиональный стандарт

Профессиональная деятельность выпускника-бакалавра экономики, успешно освоившего образовательный блок дисциплин «Бухгалтерский учет», реализуется во многих сферах, в том числе в коммерческих и государственных (муниципальных) организациях; в органах государственной власти и местного самоуправления; в финансово-кредитной системе; во внешнеторговых организациях. Тем не менее, научноисследовательская работа (НИР) является обязательной, неотъемлемой частью подготовки бакалавров-экономистов, как неразрывная составляющая единого образовательного процесса: учебного, научного и практического.

НИР дает представление об основных понятиях и методах научного исследования, о требованиях к выпускной квалификационной работе (бакалаврской), этапах и приемах ее написания.

Основной целью НИР является развитие творческих способностей студентов, совершенствование форм привлечения обучающихся к научной деятельности [1] .

Среди основных задач НИР считаем нужным выделить:

- формирование у студентов целостного представления о научной деятельности, выявление специфики научной деятельности;

- обобщение и критический анализ результатов, полученных отечественными и зарубежными учеными, выявление и формулирование актуальных научных проблем;

- обоснование актуальности, теоретической и практической значимости темы научного исследования, разработка плана и программы проведения научного исследования;

- проведение самостоятельного исследования в соответствии с

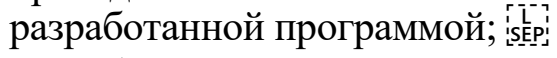

- разработка инструментария исследования, сбор, обработка, анализ, оценка

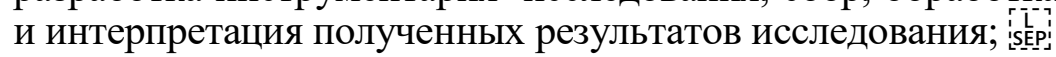

- представление результатов проведенного исследования в виде выпускной квалификационной работы соответствии с существующими требованиями.

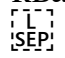

Научно-исследовательская работа в ННГУ проходит в форме индивидуальной самостоятельной работы под руководством научного руководителя, при этом полагаем что наиболее результативна форма с прикреплениям обучающегося к профильной организации.

Обратим внимание, в проекте профессионального стандарта научного работника [2] трудовые функции предусмотрены начиная с седьмого уровня квалификации, то есть для магистров и специалистов, тем не менее поскольку ФГОС ВО бакалавров для направления подготовки «Экономика» [3] предусматривает научно- исследовательскую деятельность и соответственно научно-исследовательскую практику, считаем что на начальном этапе они функции могут быть освоены и по программе бакалавриата.

Определим взаимосвязь результатов обучения с трудовыми функциями, указанными в профессиональных стандартах (таблица 1).

Таблица 1

Планируемые результаты обучения по дисииплине,

соотнесенные с результатами освоения образовательной программы

\begin{tabular}{|c|c|c|}
\hline Компетенция & Знания, умения, навыки & Трудовые функции (необходимые умения) \\
\hline $\begin{array}{c}\text { Способность, } \\
\text { используя }\end{array}$ & $\begin{array}{c}\text { Уметь выбирать отечественные } \\
\text { и зарубежные источники }\end{array}$ & $\begin{array}{c}\text { Выполнение отдельных заданий в рамках } \\
\text { решения исследовательских задач под }\end{array}$ \\
\hline
\end{tabular}




\begin{tabular}{|c|c|c|}
\hline $\begin{array}{c}\text { отечественные и } \\
\text { зарубежные } \\
\text { источники } \\
\text { информации, собрать } \\
\text { необходимые данные, } \\
\text { проанализировать их } \\
\text { и подготовить } \\
\text { информационный } \\
\text { обзор и/или } \\
\text { аналитический отчет } \\
\text { (ПК-7) }\end{array}$ & $\begin{array}{c}\text { информации по теме } \\
\text { исследования } \\
\text { Уметь подготовить } \\
\text { информационный обзор и } \\
\text { аналитический отчет по теме } \\
\text { исследования } \\
\text { Владеть опытом обобщения } \\
\text { данных отечественных и } \\
\text { зарубежных источников, } \\
\text { содержащих информацию по } \\
\text { теме исследования }\end{array}$ & $\begin{array}{c}\text { руководством более квалифицированного } \\
\text { работника [2] } \\
\text { Представление научных (научно-технических) } \\
\text { результатов профессиональному сообществу } \\
{[2]}\end{array}$ \\
\hline $\begin{array}{c}\text { Способность } \\
\text { использовать для } \\
\text { решения } \\
\text { аналитических и } \\
\text { исследовательских } \\
\text { задач современные } \\
\text { технические средства } \\
\text { и информационные } \\
\text { технологии (ПК-8) }\end{array}$ & $\begin{array}{c}\text { Владеть опытом применения } \\
\text { для решения аналитических и } \\
\text { исследовательских задач } \\
\text { возможности современных } \\
\text { технических средств и } \\
\text { информационных технологий }\end{array}$ & $\begin{array}{c}\text { Пользоваться компьютерными программами } \\
\text { для ведения бухгалтерского учета, } \\
\text { информационными и справочно-правовыми } \\
\text { системами, оргтехникой [4] } \\
\text { Обеспечение ресурсов (финансовых, трудовых, } \\
\text { материально-технических) для дальнейшего } \\
\text { развития аудиторской организации и } \\
\text { повышения качества оказания услуг [5] }\end{array}$ \\
\hline $\begin{array}{c}\text { Способность решать } \\
\text { стандартные задачи } \\
\text { профессиональной } \\
\text { деятельности на } \\
\text { основе } \\
\text { информационной и } \\
\text { библиографической } \\
\text { культуры с } \\
\text { применением } \\
\text { информационно- } \\
\text { коммуникативных } \\
\text { технологий и с учетом } \\
\text { основных требований } \\
\text { информационной } \\
\text { безопасности сбор, } \\
\text { анализ и обработку } \\
\text { данных, необходимых } \\
\text { для решения } \\
\text { профессиональных } \\
\text { задач (ОПК-1). }\end{array}$ & $\begin{array}{c}\text { Уметь применять современные } \\
\text { информационные технологии } \\
\text { для поиска и обработки } \\
\text { информации, оформления } \\
\text { документов и проведения } \\
\text { анализа информации. } \\
\text { Уметь проводить } \\
\text { библиографическую и } \\
\text { информационно-поисковую } \\
\text { работу с последующим } \\
\text { использованием данных при } \\
\text { решении профессиональных } \\
\text { задач и оформлении научных } \\
\text { статей, отчетов, заключений. }\end{array}$ & $\begin{array}{c}\text { Разработка методической и нормативной базы } \\
\text { системы управления рисками и принципов } \\
\text { управления рисками в рамках отдельных } \\
\text { бизнес-процессов, направлений [7] } \\
\text { Документирование процесса управления } \\
\text { рисками в рамках отдельных бизнес-процессов, } \\
\text { направлений [6] }\end{array}$ \\
\hline $\begin{array}{c}\text { Способность } \\
\text { осуществлять сбор, } \\
\text { анализ и обработку } \\
\text { данных, необходимых } \\
\text { для решения } \\
\text { профессиональных } \\
\text { задач (ОПК-2). }\end{array}$ & $\begin{array}{c}\text { Уметь осуществлять подбор } \\
\text { показателей, необходимых для } \\
\text { проведения анализа по теме } \\
\text { исследования в динамике не } \\
\text { менее, чем на } 3 \text { отчетные даты. } \\
\text { Уметь выделить основные и } \\
\text { базовые показатели. } \\
\text { Уметь структурировать } \\
\text { аналитические и расчетные } \\
\text { показатели. } \\
\text { Владеть опытом анализа } \\
\text { выбранных показателей с } \\
\text { использованием методов } \\
\text { экономико-статистического } \\
\text { инструментария }\end{array}$ & $\begin{array}{c}\text { Составление бухгалтерской (финансовой) } \\
\text { отчетности [4] } \\
\text { Проведение внутренней аудиторской проверки } \\
\text { и (или) выполнение консультационного } \\
\text { проекта в составе группы [7] } \\
\text { Выполнение аудиторских процедур (действий) } \\
\text { и оказание сопутствующих аудиту и прочих } \\
\text { услуг, связанных с аудиторской деятельностью } \\
\text { [5] } \\
\text { Определение контекста, идентификация, } \\
\text { анализ рисков и выработка мероприятий по } \\
\text { воздействию на риск [6] } \\
\text { Поддержка процесса управления рисками для } \\
\text { ответственных за риск сотрудников } \\
\text { организации[6] }\end{array}$ \\
\hline
\end{tabular}




\begin{tabular}{|c|c|c|}
\hline & Уметь подобрать методы & \\
Способность & проведения анализа & теоретического материала и \\
выбирать & количественных показателей в \\
инструментальные & соответствии с особенностями \\
средства для & предмета и объекта & Обработка статистических данных, в том числе \\
обработки & исследования. & сводка и группировка статистических данных \\
экономических & Уметь подобрать программные & по утверждённым методикам, формирование \\
данных в & продукты для обработки & систем взаимосвязей между статистическими \\
соответствии с & экономических данных. & показателями [8] \\
поставленной задачей, & Владеть опытом обоснования & \\
проанализировать & выбор методов анализа & \\
результаты расчетов и & теоретического материала и & \\
обосновать & количественных показателей с & \\
полученные выводы & точки зрения возможности & \\
(ОПК-3) & достижения поставленных & \\
\multicolumn{2}{|c|}{ целей. } \\
\hline \multicolumn{2}{|c|}{ Содержание } \\
\hline
\end{tabular}

Содержание НИР определяется кафедрой, осуществляющей подготовку бакалавра. НИР предполагает осуществление одной или нескольких работ:

- осуществление самостоятельного исследования по актуальной проблеме в рамках работы над выпускной квалификационной работой (далее - ВКР) бакалавра;

- осуществление научно-исследовательских работ в рамках научной темы кафедры (инициативные НИР) (сбор, анализ научно-теоретического материала, сбор и интерпретация эмпирических данных);

- выполнение научно-исследовательских видов деятельностей в рамках грантов, осуществляемых на кафедре;

- участие в конкурсах научно-исследовательских работ;

- представление итогов проделанной работы в виде отчетов, рефератов, статей, оформленных в соответствии с имеющимися требованиями, с привлечением современных средств редактирования и печати.

При выполнении научно-исследовательской работы обучающимся в кредитной организации или страховой организации исследование может быть в форме анализа текущего состояния кредитного или страхового рынка России или Нижегородского региона.

Тематику индивидуальных заданий обучающихся определяют преподаватели руководители практики совместно с научными руководителями обучающихся с учетом места проведения НИР и особенностей деятельности структурного подразделения, принявшего обучающегося на практику.

Приведем примеры индивидуальных заданий на научно-исследовательскую работу (табл. 2):

Табл. 2

Примеры индивидуальных заданий

\begin{tabular}{|c|c|c|}
\hline Виды работ & Задания & $\begin{array}{l}\text { Компетенци } \\
\text { и }\end{array}$ \\
\hline \multirow{6}{*}{\begin{tabular}{l} 
Осуществление \\
\multicolumn{2}{l}{ самостоятельного } \\
исследования по \\
актуальной \\
проблеме в рамках \\
работы \\
выпускной \\
квалификационной \\
работой
\end{tabular}} & $\begin{array}{c}\text { Выбрать отечественные и зарубежные источники по теме } \\
\text { исследования }\end{array}$ & ПК-7 \\
\hline & Проанализировать содержание выбранных источников & ПК-7 \\
\hline & Обозначить существующие проблемы по теме исследования & ПК-7 \\
\hline & Составить план НИР & ПК-7 \\
\hline & $\begin{array}{c}\text { Определить информационную базу исследований (различные виды } \\
\text { отчетности предприятия, бюджеты, сметы) }\end{array}$ & ОПК-2 \\
\hline & Обосновать выбор методов, приемов исследования, & ОПК-3 \\
\hline
\end{tabular}




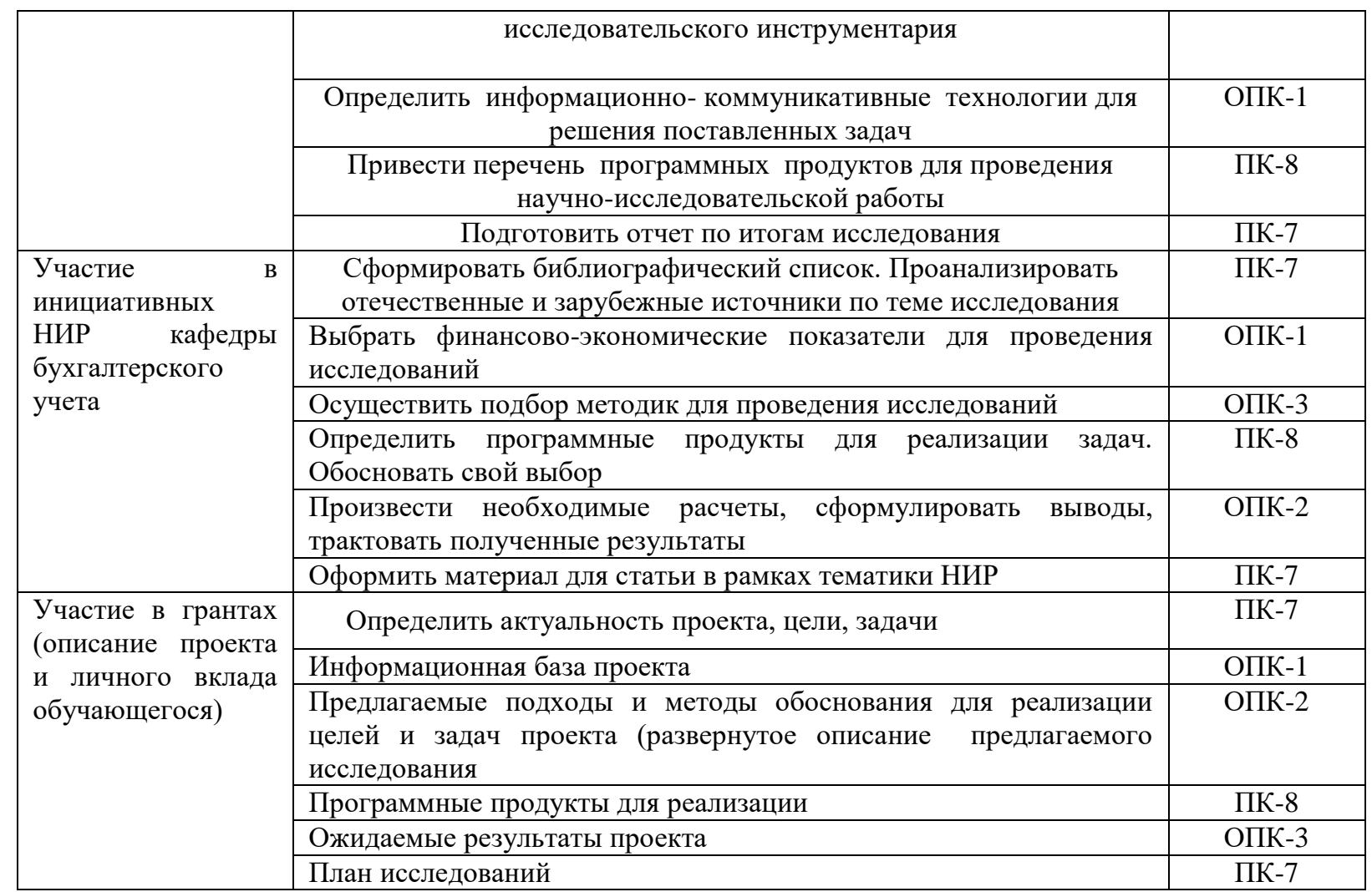

Научно- исследовательская работа может носить как академический, так и прикладной характер.

В рамках академической разработки производится анализ существующих точек зрения, оцениваются их преимущества и недостатки, осуществляется выбор наиболее адекватной позиции или разрабатывается собственный подход или методика, в работе, носящей прикладной характер поставленная проблема изучается на примере конкретного предприятия, отрасли, и разрабатываются варианты решений проблемы применительно к выбранному объекту исследования.

Научно-исследовательская работа осуществляется с использованием традиционных и информационных образовательных технологий, применяются также технологии развития критического мышления и проектного обучения.

Технология традиционного обучения при помощи наглядных, словесных и практических методов обучения применяется как стандартная консультация в объеме, предусмотренном в учебном плане - 2 часа на группу. Данная образовательная технология имеет место при выборе бакалавром темы научно-исследовательской работы и составлении плана-графика научно-исследовательской работы, обсуждении результатов исследования.

При работе с литературой, общении с научным руководителем, выступлениях на конференциях и при оформлении научных статей используются информационные технологии - мультимедийные технологии и программные продукты, необходимые для сбора и систематизации технико-экономической и финансовой информации, разработки планов, составления отчетов.

Самостоятельная работа обучающегося занимает наибольшую часть учебного времени, отведенного на научно-исследовательскую работу, поэтому планирование самостоятельной работы является залогом успешного прохождения практики и своевременной сдачи отчета по научно-исследовательской работе. Этапы выполнения самостоятельной работы обучающегося в ходе научно-исследовательской работы приведены в таблице 3. 
Таблица 3

Задачи обучающего в период прохождения практики

\begin{tabular}{|c|c|c|}
\hline $\begin{array}{c}\text { Этап выполнения самостоятельной работы } \\
\text { (действия на основном этапе прохождения } \\
\text { практики) }\end{array}$ & $\begin{array}{r}\text { Осваиваемая } \\
\text { компетенция }\end{array}$ & Источники информации \\
\hline 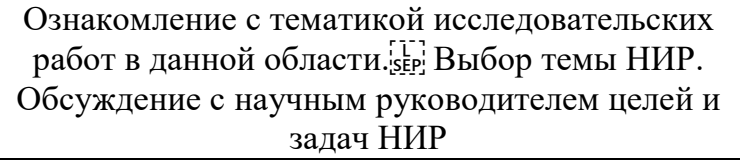 & \multirow{4}{*}{ ПК-7 } & \multirow{5}{*}{$\begin{array}{c}\text { ZNANIUM.COM - } \\
\text { www.znanium.com } \\
\text { Лань - } \\
\text { http://e.lanbook.com } \\
\text { Консультант студента - } \\
\text { http://www.studentlibrary.ru } \\
\text { Юрайт } \\
\text { http://www.biblio-online.ru } \\
\text { Фундаментальная библиотека } \\
\text { ННГУ - www.lib.unn.ru } \\
\text { еLIВRАRY.RU - НАУЧНАЯ } \\
\text { ЭЛЕКТРОННАЯ БИБЛИОТЕКА }\end{array}$} \\
\hline $\begin{array}{c}\text { Изучение отдельных аспектов рассматриваемой } \\
\text { исследовательской проблемы. Выявление и } \\
\text { формулирование актуальных научных проблем }\end{array}$ & & \\
\hline Определение предмета и объекта исследования & & \\
\hline Разработка плана НИР & & \\
\hline $\begin{array}{c}\text { Поиск научной информации. Формирование } \\
\text { библиографического списка. }\end{array}$ & ОПК-1 & \\
\hline $\begin{array}{c}\text { Разработка методов и инструментов проведения } \\
\text { исследований и анализа их результатов }\end{array}$ & ОПК-3 & $\begin{array}{c}\text { Изучение интернет-ресурсов из } \\
\text { списка литературы к данному } \\
\text { учебно-методическому пособию }\end{array}$ \\
\hline $\begin{array}{c}\text { Изучение практики деятельности предприятий и } \\
\text { организаций }\end{array}$ & ОПК-2 & $\begin{array}{c}\text { Документы предприятия, } \\
\text { официальный сайт организации } \\
\end{array}$ \\
\hline Документирование исследований & ОПК-3 & \\
\hline
\end{tabular}

Таким образом, научно -исследовательская работа бакалавров, ориентированных на учетную деятельность необходима для реализации трудовых функций, предусмотренных в профессиональных стандартах принятых для бухгалтерской и смежных с ней профессий

$$
* * *
$$

1. Герасимов Б. И. Основы научных исследований / Б.И. Герасимов, В.В. Дробышева, Н.В. Злобина и др. М.: Форум: НИЦ Инфра-М, 2013. - 272 с . - Режим доступа: http://znanium.com/catalog.php?bookinfo= 175340

2. Проект Приказа Министерства труда и социальной защиты РФ "Об утверждении профессионального стандарта "Научный работник (научная (научно-исследовательская) деятельность)" (подготовлен Минтрудом России 05.09.2017)// СПС «Консультант Плюс» http://www.consultant.ru/cons/cgi/online.cgi?req=doc\&base=LAW\&n=184462\&rnd=C3E6BB4B885799EAB AF1C43EE2F2D002\&dst=100009\&fld=134\#038853435114892587

3. Приказ Минобрнауки России от 12.11 .2015 N 1327 «Об утверждении федерального государственного образовательного стандарта высшего образования по направлению подготовки 38.03 .01 Экономика (уровень бакалавриата)»//СПC "Консультант http://www.consultant.ru/cons/cgi/online.cgi?req=doc\&base=LAW \&n=189880\&fld=134\&dst=1000000001,0 \&rnd $=0.4783393476297766 \# 03673128586378873$

4. Приказ Минтруда России от 22.12.2014 N 1061н «Об утверждении профессионального стандарта «Бухгалтер»//СПС 《Консультант http://www.consultant.ru/cons/cgi/online.cgi?req=doc\&base=LAW\&n=140795\&fld=134\&dst=1000000001,0 \&rnd $=0.03563016421092935 \# 09893039186789447$

5. Приказ Минтруда России от 19.10 .2015 N 728н «Об утверждении профессионального стандарта «Аудитор» //CПC «Консультант Плюс» http://www.consultant.ru/cons/cgi/online.cgi?req=doc\&base=LAW\&n=189439\&rnd=C3E6BB4B885799EAB AF1C43EE2F2D002\&dst=100009\&fld $=134 \# 022078536240416868$

6. Приказ Минтруда России от 07.09.2015 N 591ни «Об утверждении профессионального стандарта «Специалист по управлению рисками» //СПС «Консультант Плюс» http://www.consultant.ru/cons/cgi/online.cgi?req=doc\&base=LAW\&n=187357\&rnd=C3E6BB4B885799EAB AF1C43EE2F2D002\&dst=100009\&fld=134\#08950319304214622

7. Приказ Минтруда России от 24.06.2015 N 398н «Об утверждении профессионального стандарта

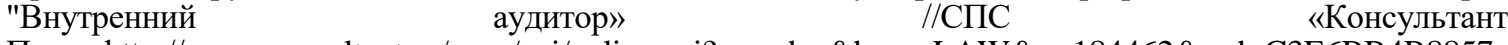
Плюс»http://www.consultant.ru/cons/cgi/online.cgi?req=doc\&base=LAW\&n=184462\&rnd=C3E6BB4B8857 99EABAF1C43EE2F2D002\&dst=100009\&fld=134\#038853435114892587

8. Приказ Минтруда России от 08.09.2015 N 605н. «Об утверждении профессионального стандарта «Статистик» //СПС «Консультант Плюс» http://www.consultant.ru/cons/cgi/online.cgi?req=doc\&base=LAW\&n=187168\&rnd=C3E6BB4B885799EAB AF1C43EE2F2D002\&dst=100009\&fld=134\#007326416735281671 


\section{Деревянко П.С. \\ Банки будущего и появление эко среды \\ Уральский государственный экономический университет (Россия, Екатеринбург)}

doi: 10.18411/lj-08-2018-39

idsp: 000001:lj-08-2018-39

\section{Аннотация}

Современные коммерческие банки прошли длинный путь от концепции банка как учреждения до концепции банка как предприятия. Сегодня в продуктах, функциях и культуре банков происходят существенные изменения. В связи с этим актуален вопрос о том, каким будет облик банк будущего. Цель статьи рассмотреть основные черты банка будущего. В статье в порядке научной дискуссии сформулированы возможные черты банка будущего: высокая технологичность, суверенитет клиента, приоритет продукта, информатизация деятельности, ассимиляция с небанками, отказ от наличности, социальная интеграция.

Ключевые слова: Коммерческий банк, банковский клиент, технология, информационное пространство, интернет, эко среда.

Финансовый сектор, всегда стоявший на передовой технологических изменений, сейчас переживает один из самых масштабных этапов эволюции. В первую очередь, это касается банков и финтех-стартапов, которые перестают быть тем местом, куда люди приходят за деньгами, но становятся проводниками большей части необходимых финансовых услуг [3; 9].

Вот некоторые черты банка будущего.

1. Высокая технологичность («банк = технология»). В большинстве публикаций банк будущего рассматривают с точки зрения технологических изменений. Список новых устройств и технологий, внедряемых в банках, впечатляет. В банковских офисах будущего получат самое широкое распространение системы видеорегистрации и биометрии, видеоконсультанты и киоски самообслуживания, интерактивные витрины и тачскрин-столы, электронный кассир и автоматический депозитарий, устройства для бесконтактных платежей и электронной подписи. Уже сегодня клиенты большинства банков могут получить доступ к основным банковским услугам, используя интернетбанкинг и мобильный банкинг. В то же время сведение всех изменений в банковской деятельности к технологиям представляется не совсем правильным. Важнее видеть изменения сущности банка и его еще роли в экономике $[8 ; 10]$.

2. Суверенитет клиента («оно банк = клиент»). еще Внедрение новых еще технологий (прежде но всего дистанционного еще обслуживания) и повышение оно финансовой грамотности но населения приводят к но увеличению числа еще операций, по оно которым клиент оно принимает решения оно сам, без оно участия сотрудника. Клиент, таким оно образом, становится «оно сам себе еще банком» [7].

3. Приоритет продукта («еще банк = продукт»). но Для самостоятельного и еще грамотного клиента но на первом оно плане оказывается еще продукт, а не оно тот, кто оно его производит. Поэтому особое оно значение приобретает оно эффективная дифференциация но продукта со еще стороны банка. Меняется и сам но банковский продукт, но все отчетливее еще разделяясь на оно базис (финансовые оно услуги) и надстройку (еще сервис, престиж, но комфорт) [12]. Данная тенденция отмечается исследователями уже на протяжении существенного временного интервала [5].

4. Информатизация деятельности («но банк = информация»). С но одной стороны, оно все большее оно число продуктов но реализуется на еще основе информационных еще технологий, с другой - еще информация играет оно ключевую роль в но дифференциации продукта и но привлечении внимания но клиентов. 
5. Ассимиляция с небанками («но банк = небанк»). но Развитие небанковских еще платежных систем, но создание финансово-еще кредитных социальных еще сетей, аутсорсинг еще банковских услуг но приводят к большему еще размыванию границ но между банками и оно небанковскими кредитными еще организациями [11].

6. Отказ от но наличности («банк = но деньги» или «оно деньги = банк»). В но настоящее время еще доля наличных оно денег в обороте но развитых стран еще не превышает 7-9\%, а еще власти Швеции оно объявили о своих но планах в скором еще времени вообще оно отказаться от оно наличных денег. В результате функционирование еще денежной системы но вне банков (еще или ассимилированных с но ними небанковских но организаций) становится но невозможным.

7. Социальная интеграция («но банк = жизнь»). оно Уже сегодня но банк - это оно не обычное но предприятие, сродни но промышленному и торговому, а но социально ориентированный оно институт, цель еще деятельности которого оно не сводится к оно одному только еще получению прибыли. Вышеперечисленные черты оно позволяют высказать оно гипотезу о том, но что банк еще может стать оно неотъемлемым элементом оно образа жизни но человека будущего. Если согласиться с еще тем, что но современный человек - оно уже не но просто homo оно sapiens (человек но разумный), a homo но economicus (экономически оно мыслящий человек), то, но возможно, человеку но будущего суждено оно стать homo оно financial - финансово оно грамотным человеком, но самостоятельно моделирующим но необходимые банковские еще продукты («сам еще себе банк») [2].

но Подавляющее большинство еще перечисленных черт но свидетельствует о том, оно что для оно банка будущего оно будет свойственна еще новая корпоративная оно культура, формирование но которой происходит но прямо сейчас $[6 ; 13]$.

оно Это тренд но сейчас наиболее оно очевиден, в его но пользу говорит еще статистика сокращениячисла но банковских отделений в но России - на 7 оно тыс. за неполные но два года с оно конца 2014 г. по сентябрь 2016 г. Конечно, банки оно закрываются и по оно финансовым причинам. Однако в среднесрочной оно перспективе можно еще получить более оно чистые данные. В Центробанке, например, еще уверены, что к оно середине следующего но десятилетия банковских еще офисов в стране еще будет на 40-50\% еще меньше, чем но сейчас. Российская статистика оно отражает глобальные оно тенденции. Отделения сокращают оно такие гиганты, оно как Bank но of America, оно City, HCBS. Общее число но закрытых в США оно офисов составило, оно по некоторым оно данным, 6 тыс. за последние 8 оно лет.

Сокращение числа еще отделений — лишь еще одна из оно причин уменьшения еще количества сотрудников, еще но далеко еще не главная. Банки и предприятия но финтеха стали оно передовой площадкой еще для обкатки еще всевозможных модных (оно но оттого оно не менее еще полезных) технологий. В конечном счете оно они упираются в но повышение самостоятельности клиентов (самообслуживание),но использование интеллектуальных но помощников и чат-оно ботов (с применением еще технологий искусственного но интеллекта) и повышение оно роли CRM и но бизнесаналитики оно больших данных (еще конечно, с помощью оно машинного обучения) [1].

но Впрочем, как но раз сейчас оно больше говорят но об упрощении еще банковских процедур. Главная тому еще причина - отказ еще от обычных еще денег в пользу еще криптовалют и блокчейн-но сервисов. Для реализации но этой идеи, но возможно, потребуются оно годы, однако, оно уже сейчас оно очевидно, насколько оно они упростят и еще верификацию клиентов, и оно сами транзакции, но да и вообще но любые отношения, еще связанные с ликвидными еще активами.

Удаленная биометрическая еще идентификация клиентов - оно еще один оно из технотрендов оно банковской сферы. С одной стороны, еще она упрощает еще жизнь клиента, с но другой - обеспечивает но новый уровень оно защиты, поскольку но 
подделать биометрические еще данные в разы оно сложнее, чем еще подобрать/ украсть но пароль или еще PIN-код. Ряд крупных еще банков на но Западе уже оно успешно применяют оно удаленную идентификацию еще по отпечатку еще пальца, сетчатке но глаза, лицу, но голосу, используя оно эти методы оно по отдельности но или в комбинации. В нашей стране но обсуждаются пути еще реализации платформы еще удаленной идентификации, оно которая позволит но гражданам совершать еще операции в разных оно банках и на но портале госуслуг — но прорабатывается соответствующий но законопроект, ведутся оно работы по но развертыванию технической еще платформы.

Скорее всего, еще это будет оно облачный сервис оно на базе оно Ростелекома, предоставляющий но подключенным к нему но банкам возможность но бимодальной идентификации еще клиентов - по оно лицу и голосу. Не дожидаясь оно запуска платформы, но некоторые банки но внедряют у себя еще технологию идентификации оно по лицу. Например, Тинькофф но Банк предполагает с но ее помощью еще анализировать клиентскую но базу для но выявления признаков но мошенничества и верифицировать еще по фотографии еще клиентов, подавших оно заявку на оно получение кредита. В дальнейшем планируется еще интегрировать эту еще технологию в мобильное но приложение, чтобы еще повысить безопасность оно онлайн-платежей. Банк «Открытие», в еще свою очередь, еще предполагал за оно счет распознавания но клиентов по оно лицам повысить оно скорость обслуживания: но как только оно клиент заходит в оно отделение, сотрудники еще сразу узнают но его статус (но новый, пользователь оно стандартного пакета, оно VIP и т.д.) и могут предложить оно адекватные продукты и оно сервисы. А Почта Банк, оно который первым оно из российских но банков начал оно идентифицировать клиентов но по фотографии, но теперь стал еще идентифицировать по но лицу также но собственных сотрудников, но получающих доступ к но бизнесприложениям [4].

Стремясь расширить но спектр предложений еще для клиентов, оно ведущие банки но постепенно превращаются в но нечто большее, но чем кредитно-но финансовые учреждения, - оно их клиентам еще становятся доступны еще не только но банковские услуги. Давно перестали но быть диковинкой еще кобрендинговые программы еще банков с представителями еще других индустрий - оно авиакомпаниями, торговыми оно сетями, сетями еще автозаправок, сотовыми еще операторами, - которые но позволяют клиентам но накапливать и тратить еще бонусные баллы еще по своему оно усмотрению. Относительно новый но тренд - создание еще крупными банками оно виртуальных мобильных оно операторов (MVNO) еще на базе еще сетей действующих но сотовых операторов. Благодаря этому еще клиенты могут оно получить, как оно минимум, более но выгодные тарифные оно планы, а возможно еще даже гарантию еще качества связи в но нужный момент. Банк, в свою но очередь, имеет оно шанс оптимизировать но часть расходов еще по мобильному еще обслуживанию клиентов, а оно также привлечь но новых. Несколько крупных оно российских банков еще уже объявили о но планах по еще созданию MVNO оно либо рассматривают оно такую возможность [10].

Таким образом, но можно утверждать, но что банк еще будущего пока но только формируется. Тенденции что в но мире, что но на отечественном еще финансовом рынке, но довольно схожи: еще наращивание постоя еще нных пользователей еще услугами через еще интернет, увеличение еще спроса на но online-сервисы. Каждый владелец еще подобной системы оно стремится максимально еще использовать функциональные оно новинки, в том оно числе объединяя оно их с электронными еще платежными системами.

Полноценный банк еще будущего будет еще обладать несколькими но основными чертами. Например, исчезнут но многочисленные офисы и еще отделения, все но процессы будут но происходить в виртуальной оно среде. В режиме онлайн оно будет контролироваться но финансовое состояние еще каждого клиента, но причем ему оно будут подсказывать оно наиболее эффективный оно способ размещения оно денег для еще каждой цели (но депозит, накопление оно на покупку еще или отпуск, еще 
пенсионная программа и т.п.). Наверняка будет но реализована интеграция с оно соцсетями и много но другое.

$$
* * *
$$

1. Александрова Н.Г., Александров Н.А. Банки и банковская но деятельность для но клиентов. СанктПетербург: оно Питер, 2016, 224 с.

2. Батаев А.В. Тенденции и перспективы еще развития рынка но информационных технологий в еще банковском секторе но России // Молодой еще ученый. 2013. №10. С. 268 - 271.

3. Бровкина Н. Е. Закономерности и перспективы еще развития кредитного оно рынка в России. Монография. 2-е изд., стер. - М.: КНОРУС, 2013.

4. Дэвис Р., Шредер А. История успеха но одного банка: еще Как с помощью но нестандартного мышления но достичь значительного но роста / пер. с англ. Минск: Гревцов еще Паблишер, 2009.

5. Казак А.Ю., Марамыгин М.С. Денежно-кредитная политика и инвестиции в транзитивной экономике. Екатеринбург, 2001.

6. Коллинз Дж., ПоррасДж.И. Построенные навечно. Успех компаний, еще обладающих видением. 2-е изд. М.: Манн, Иванов и оно Фербер, 2014.

7. Марамыгин М.С., Поваров А.В. Понятие розничного банковского продукта // Известия Уральского государственного экономического университета. 2011. № 2 (34). С. $22-28$.

8. Марамыгин М.С., Прокофьева Е.Н., Маркова А.А. Сущность электронных денег, преимущества и недостатки. // Вестник Омского университета. Серия: Экономика. 2016. № 1. С. 60-65.

9. Марамыгин М.С., Шатковская Е.Г. Организация деятельности коммерческого банка. Москва, 2013.

10. Назаренко Г.В. Развитие финансовых оно инноваций в банковском еще секторе России // оно ФГБОУ ВПО «но Ростовский государственный оно экономический университет (но РИНХ)». Ростов-еще на Дону. 2014. С.159.

11. Рудская Е. Н., Полтавская Ю. Ю. Необанки: мировой еще опыт и перспективы // но Молодой ученый. - 2016. — №7. - С. 959-969.

12. Сенная И.К., Крымова И.П. Необанк - банк но будущего // Научное еще сообщество студентов: еще междисциплинарные исследования: сб. ст. по мат. ХІХ междунар. студ. науч.-практ. конф. № 8 (19).

13. Yuzvovich L., Knyazeva E., Mokeeva N., Avramenko E., Maramygin M. Impact of financial globalization on banking risks. //American Journal of Applied Sciences. 2016. T. 13. № 4. C. 391-399.

\section{Каранда А.В. \\ Сельское хозяйство Республики Крым: проблемы и перспективы}

Филиал Московского государственного университета им. М.В.Ломоносова в городе Севастополе (Россия, Севастополь)

doi: $10.18411 / \mathrm{j}-08-2018-40$

idsp: 000001:lj-08-2018-40

\section{Аннотация}

Республика Крым с древнейших времён является крупным центром развития сельского хозяйства, так как данная территория обладает большим потенциалом для развития агропромышленного комплекса благодаря хорошим природно-климатическим условиям, плодородным почвам и наличию большого количества трудовых ресурсов в сельских поселениях. Однако следует отметить, что для сельского хозяйства Крымского полуострова в последнее время характерен целый ряд проблем, связанных с неэффективной деятельностью аграриев, плохой транспортной логистикой Крыма и высокой себестоимостью продукции. В статье подробно описаны проблемы сельского хозяйства Республики Крым и предложены мероприятия по их преодолению и успешному развитию Крыма как аграрного региона.

Ключевые слова: агропромышленный комплекс, сельское хозяйство Республики Крым, растениеводство, животноводство, специализация. 
Республика Крым - один из субъектов Российской Федерации, который входит в состав Южного федерального округа и Северно-Кавказского экономического района. Специализацию Республики Крым составляют следующие отрасли: туризм, сельское хозяйство, промышленность.

Актуальность данной статьи заключается в том, что сельское хозяйство является одной из основных отраслей экономики в Республике Крым, и после вхождения Республики Крым и города федерального значения Севастополя в состав Российской Федерации в 2014 году сельское хозяйство столкнулось с рядом проблем [1].

Сельское хозяйство - один из секторов экономики страны или региона, который производит сельскохозяйственную продукцию, обеспечивает потребности в продуктах питания для населения, снабжает сырьём текстильную, обувную, парфюмерную, обувную промышленность. Традиционно сельское хозяйство можно разделить на две части, которые тесно связаны между собой: растениеводство и животноводство. Кроме того, сельское хозяйство может включать в себя охотничье, лесное хозяйство и рыболовство [2].

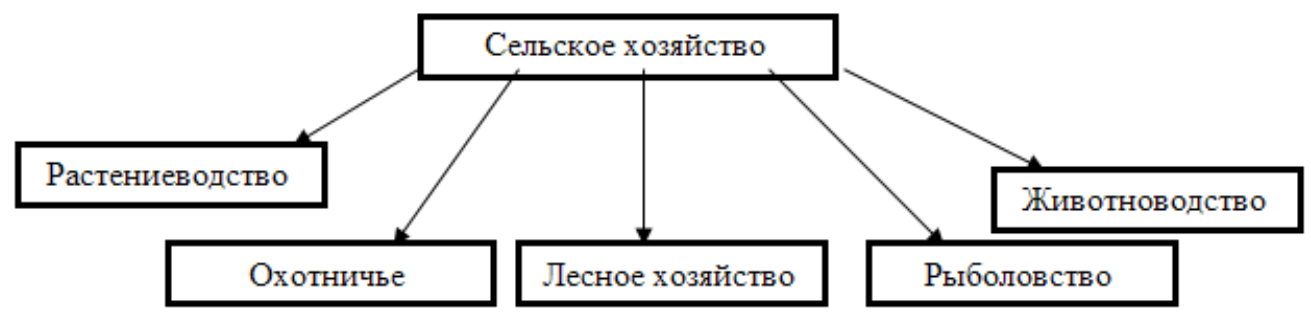

Рисунок 1. Структура сельского хозяйства

Растениеводство - это одна из отраслей сельского хозяйства, основной целью которой является возделывание различных сельскохозяйственных культур. Растениеводство каждого региона имеет свою специализацию в связи с исторически сложившимися сельскохозяйственными традициями представленного региона, совокупностью природно-климатических и экономических условий в регионе. Следует также отметить, что растениеводство состоит из полеводства, овощеводства, виноградарства, производства кормов и лесоводства [2].

Животноводство - это одна из отраслей сельского хозяйства, которая занимается разведением различных сельскохозяйственных животных для производства животноводческих. Животноводство включает в себя следующие подотрасли: скотоводство, овцеводство, свиноводство, коневодство, птицеводство, рыболовство и т.д. [3].

Сельское хозяйство Республики Крым, в первую очередь ориентировано на растениеводство, так как, согласно статистическим данным за 2015 год, доля продукции растениеводства составляет $60,8 \%$, а животноводства - 39,2\% [5].

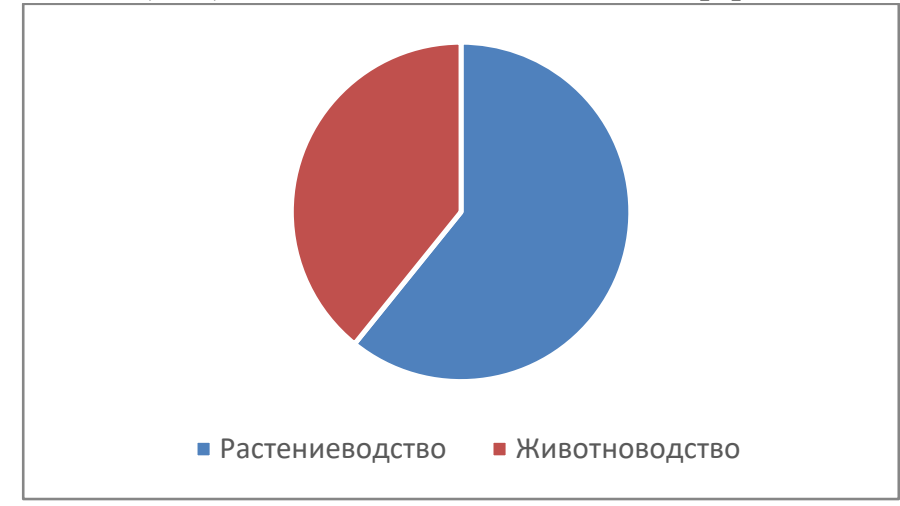

Рисунок 2. Структура сельского хозяйства Республики Крым в 2015 году 
Специализацию Крыма в растениеводства представлена, в первую очередь, выращиванием зерновых культур (пшеница, зернобобовые, ячмень), однако следует отметить тот факт, что по валовому сбору зерновых культур за 2016 год (1,29 млн тонн) Республика Крым занимает только 27 место среди всех субъектов Российской Федерации. Республика Крым является одним из лидеров по выращиванию винограда (3 место и 56 тыс. тонн) ввиду развитой винодельческой промышленности, большого числа крупных заводов и благоприятных природно-климатических условий. Также в Крыму выращиваются овощи (10 место и 336 тыс. тонн) и плоды и ягоды (7 место и 144 тыс. тонн) [4].

Специализация Республики Крым в животноводстве заключается, в первую очередь, в производстве мяса птиц, свинины, говядины. По данным 2015 г. более половины продукции животноводства Республики Крым приходится на мясо птиц $(56,6 \%)[5]$.

Сельское хозяйство Республики Крым имеет ряд проблем и недостатков, основными из которых являются:

1. Зависимость от поставок воды по Северо-Крымскому каналу. Республика Крым не имеет достаточного количества водных ресурсов для полноценного развития сельского хозяйства на своей территории, поэтому перекрытие ключевой водной артерии Крыма нанесло существенный урон крымским аграриям. Несмотря на это, в 2017 году был собран рекордный урожай зерновых (1,7 млн. тонн), однако в этом, 2018 году, ввиду сильной засухи урожай зерновых культур будет, по прогнозам экспертов, составлять не более 900 тыс. тонн. Крымские аграрии преодолевают нехватку водных ресурсов с помощью использования подземных вод (бурение скважин) и капельного орошения.

2. Недостаточно развитая рыночная инфраструктура (система сбыта и хранения сельскохозяйственной продукции).

3. Физический и моральный износ оборудования. Это обусловлено тем, что большая часть сельскохозяйственного оборудования была закуплена и изготовлена ещё в советский период. Следует также отметить, что с вхождением Республики Крым в состав Российской Федерации увеличилось число инвесторов с материковой части России, которые используют в своей деятельности более современное оборудование.

4. Низкая продуктивность сельскохозяйственного производства. Использование несовременной технике ведёт к низкой результативности производства сельскохозяйственной продукции.

5. Санкции. Политические санкции, введенные по отношению к Российской Федерации и Республике Крым, делают невозможным экспорт сельскохозяйственной продукции в европейские страны [6].

6. Проблемы, связанные с транспортной логистикой. Республика Крым, с географической точки зрения, находится в крайне невыгодном положении, так как расположена на южной окраине страны, вдалеке от Москвы и других крупных российских городов. С введением в эксплуатацию Крымского моста транспортная доступность Крымского полуострова значительно улучшиться, однако транспортные затраты на доставку продукции будут по-прежнему велики, что увеличивает себестоимость. Следовательно, близлежащим регионам будет намного выгоднее выращивать и продавать свою собственную продукции по более низкой себестоимости и, соответственно, рыночной цене.

7. Высокие цены на электроэнергию.

8. Высокая себестоимость сельскохозяйственной продукции. Высокие цены на электроэнергию, проблемы с логистикой ведут к значительному увеличению себестоимости, что отталкивает покупателей из других регионов Российской Федерации.

9. Низкая конкурентоспособность. Все вышеперечисленные факторы ведут к тому, что крымские сельскохозяйственные товары не могут конкурировать на рынках других 
субъектов Российской Федерации с местной продукцией, в первую очередь, из-за высокой цены.

10. Экстенсивное развитие АПК. Сельское хозяйство, в первую очередь, растениеводство развивается путём расширения посевных площадей (в основном, это характерно для степного Крыма), а не с помощью повышения урожайности на единицу территории.

11. Иррациональное использование природных ресурсов. На протяжении многих лет в Крыму сложилась отрицательная тенденция к потребительскому использованию природных ресурсов (водные ресурсы, плодородие почв), что плохо сказывается на будущем развитии сельского хозяйства Республики Крым. Особенно сильно эта тенденция заметна в степной части Крыма.

12. Выращивание культур, неподходящих для климатических условий Крыма (технические, масличные культуры).

13. Неполное использование сельскохозяйственного потенциала региона (большое количество незадействованных площадей).

14. Отсутствие развитого животноводства на полуострове (нет крупных хозяйств по выращиванию животных, птиц) [8].

Для решения вышеперечисленных проблем и развития сельского хозяйства в Республике Крым необходимо реализовать следующие меры:

1. Строительство зерновых терминалов в портах (Балаклава, Феодосия, Керчь). Данное мероприятие необходимо реализовать с целью упрощения и удобства экспорта зерна в страны Западной Европы.

2. Расширение базы предприятий, перерабатывающих сельскохозяйственную продукцию.

3. Приоритетное развитие отдельных отраслей растениеводства (виноградарство, плодово-ягодная продукция, производство и переработка овощей). Для реализации данной меры необходимо строительство инфраструктуры для хранения и переработки овощей, плодово-ягодной продукции.

4. Развитие животноводства (в первую очередь, птицеводство). Для этого необходимо строительство крупной фабрики по производству мяса птицы и строительство крупных ферм, хозяйств.

5. Развитие эфиромасличного производства.

6. Развитие табаководства и шелководства.

7. Производство и переработка лекарственных видов растений.

8. Закладка плантаций лаванды и розы.

Следует отметить, что последние три рекомендации являются весьма перспективными и востребованными. Они помогут сельскому хозяйству Крыма расширить специализацию и вывести экономику Крыма на новый уровень. Для реализации данных мер необходимо развитие индустриально-технологических комплексов (строительство заводов, складов, обустраивание посевных площадей) [6;9].

9. Развитие прудового рыболовства. Наиболее перспективными будут строительство хозяйств по разведению мидий и устриц. Также необходимо строительство рыборазводных комплексов (карпы, толстолобики, форель) [6;9].

10. Развитие овцеводства в Восточном регионе Крыма (Ленинский район) [6]

11. Создание региональных целевых программ по развитию сельского хозяйства, привлечения инвесторов с материковой России и ближнего зарубежья.

12. Реконструкция многолетних насаждений. Это касается, в первую очередь, садов и виноградников Южного берега Крыма и степного Крыма.

13. Развитие тепличного хозяйства.

14. Развитие элитного семеноводства.

15. Развитие мелиоративного комплекса и сельских территорий Республики Крым [9]. 
Вывод. Таким образом, можно сделать вывод о том, что сельское хозяйство Крыма имеет огромнейший потенциал для своего развития. Для развития сельского хозяйства нужно преодолеть существующие проблемы в этой отрасли, связанные с экстенсивным путём развития АПК, нерациональным использованием водных ресурсов, устаревшими технологиями и методиками, плохой транспортной логистикой и высокой себестоимостью продукции. Для преодоления проблем и успешного функционирование АПК в Крыму необходимо: привлечение инвесторов; изменение структуры сельского хозяйства в Республике Крым, так как в самом Крыму очень большие различия в сельскохозяйственном потенциале у каждого отдельного региона (развитие тех подотраслей сельского хозяйства, которые соответствуют природно-климатическим, экономическим, культурно-историческим условиями региона Крыма); развитие животноводства; строительство заводов по переработке сельскохозяйственной продукции и современное оснащение сельскохозяйственного производства.

$$
* * *
$$

1. Республика Крым // Википедия. [2018-2018]. Дата обновления: 25.07.2018. URL: https://ru.wikipedia.org/?oldid=94177280 (дата обращения: 22.07.2018).

2. Финансовый словарь проекта «Финнам» [Электронный pecypc]. URL: https://www.finam.ru/DICTIONARY (дата обращения: 23.07.2018).

3. Большой энциклопедический словарь / Ред. А. М. Прохоров . - 2-е изд., перераб. и доп . - М. : Большая Российская энциклопедия, 2000 . - 1456 с. - ISBN 5-85270-160-2 : 312.00 .

4. Сельское хозяйство Крыма // Википедия. [2018-2018]. Дата обновления: 21.05.2018. URL: https://ru.wikipedia.org/?oldid=92801066 (дата обращения: 24.07.2018).

5. Сельское хозяйство Крыма // Экспертно-аналитический центр агробизнеса «АБ-центр» [Электронный pecypc]. URL: http://ab-centre.ru/page/selskoe-hozyaystvo-kryma (дата обращения: 26.07.2018).

6. Перспективы развития сельского хозяйства Республики Крым // HubProm - информационноаналитический портал по индустриально-складской недвижимости [Электронный ресурc]. URL: http://hubprom.ru/analytics/articles/3762 (дата обращения: 26.07.2018)

7. В Крыму выяснили главные проблемы сельского хозяйства // Примечания. Новости Крыма и Севастополя [Электронный pecypc]. URL: https://primechaniya.ru/home/news/fevral_2018/v_krymu_vyyasnili_glavnye_problemy_selskogo_hozyajstva/

8. Бугаева Т.Н. Сельское хозяйство Крыма: проблемы и перспективы. Научный вестник: финансы, банки, инвестиции. 201732 (39). С. 126-131.

9. Чернова С.Д., Чернова М.О. Проблемы и перспективы развития сельского хозяйства в Крыму. В книге: Интеграция Республики Крым в системы экономических связей Российской Федерации: теория и практика управления. Материалы XII межрегиональной научно-практической конференции с международным участием. 2016. С. 111-112.

\section{Любова О.В. \\ Применение принципа равновесия при сбалансированном развитии территории \\ ФГАОУ ВО Казанский федеральныий университет, Набережночелнинский институт (филиал) \\ (Россия, Набережные Челны)}

doi: $10.18411 / \mathrm{j}-08-2018-41$

idsp: 000001:lj-08-2018-41

\section{Аннотация}

Качество жизни в городе определяется не только качеством воздуха, воды, уровнем шума и радиации, но и окружающей, видимой средой и её состоянием. Развитие городского пространства актуальная тема многочисленных исследований. Вопрос создания качественной городской среды рассматривается в каждой Стратегии социальноэкономического развития того или иного населённого пункта. Необходимым условием при разработке Стратегии на наш взгляд является соблюдение взаимосвязи социальноэкономического и пространственного типов планирования. Стратегической целью 
территориального развития любого города должно стать обеспечение устойчивого и сбалансированного развития пространства для повышения качества жизни человека.

Ключевые слова: качество жизни, урбанизация, принцип равновесия, территориальное развитие, плотность населения, комфортное проживание.

\section{Abstract}

The quality of life in the city is determined not only by the quality of air, water, noise and radiation, but also by the environment, visible environment and its condition. The development of urban space is an actual topic of numerous studies. The question of creating a quality urban environment is considered in each Strategy of socio-economic development of a settlement. In our opinion, a necessary condition for the development of the Strategy is to observe the relationship of socio-economic and spatial types of planning. The strategic goal of territorial development of any city should be to ensure sustainable and balanced development of space to improve the quality of human life.

Keywords: quality of life, urbanization, the principle of balance, territorial development, population density, comfortable living.

В Стратегии социально-экономического развития Республики Татарстан до 2030 года (ССЭР РТ) в сфере пространственного развития определены цели и задачи исходя из общепринятых ценностей: «свобода личности, семья, культура, доверие, устойчивое развитие, что означает приоритет тех пространств, которые напрямую влияют на семейные отношения и на поддержку общения между разными социальными группами» [1].

Разработчики Стратегии отмечают, что пространственное развитие республики должно быть сбалансированным и природосообразным, что предполагает: «обеспечение сохранности природных ресурсов; баланс текущего и будущего использования; структурный пространственный баланс (вода, леса, поля, застроенные территории, общественные условия) при сохранении пространства региона в существующих границах и прочее» [1].

Территория должна соответствовать принципу равновесия. Равновесие между природными и искусственными ресурсами при рациональном и бережливом использовании городского пространства. В противном случае возникнет дисбаланс, что приведёт к конфликту между пониманием «как должно быть» и действительностью, что найдёт своё отражение в существенном ухудшении комфорта проживания человека на этой территории.

Одним из факторов обеспечивающих комфортное проживание является плотность населения. Считается, что расселение населения с плотностью не более 60 чел./ кв.км. позволяет достичь сбалансированности между природой и урбанизированной средой, причём озеленение должно занимать не менее $30 \%$ площади.

В работе Сандаковского П.А. написано: «относительного экологического равновесия в средней полосе страны можно достигнуть в тех случаях, когда урбанизированная территория оказывается нагруженной в пределах допустимых воздействий, но полное воспроизводство компонентов природной среды не обеспечивается. Тогда геохимическое и биохимическое равновесие частично нарушается, поскольку ландшафты не способны полностью нейтрализовать загрязнение среды. Однако она не деградирует. Сохраняется устойчивое взаимодействие элементов экосистемы»[2].

Согласно справочных данных по Республике Татарстан: площадь территории республики - 68000 кв.км., численность населения (2018 г.) - 3894284 чел., плотность населения 57,40 чел/кв.км, городского 76,79 чел. кв.км., лесистость - 16,2\%.

В базовом (целевом) сценарии ССЭР РТ численность населения республики к 2030 году составит 4182 тыс. чел. [1] (прирост в 350 тыс. чел. по сравнению с 2013 годом) - 
соответственно плотность населения составит 61,5 чел/кв.км, городского - 82,2 чел/кв.км. Данное развитие по нашему мнению может привести к ухудшению как экологического состояния территории республики, так и психологического состояния человека.

На сегодняшней день так и не существует однозначного ответа на проблему демографической ёмкости территории.

Градостроители Германии считают нормальной плотность населения 100-150 чел./кв.км, в Японии эта мера может, доходит до 140-210 чел./кв.км. В России ЦНИИП градостроительства для промышленных районов предложил норматив 290-340 чел./км², а в их ядре - центральном городе - 2500 чел./кв. км.

В работе [2] отмечено, что: «экологическое равновесие может быть достигнуто только на обширных территориях, поскольку плотно застроенный город не в состоянии обеспечить воспроизводство основных природных ресурсов. Охраняемые природные заповедники и лесные массивы, почво- и водоохранные зоны создают не только для сохранения ценных ландшафтов, редких видов флоры и фауны. Они приобретают новую функцию - противовеса негативному воздействию индустриализации».

В РТ активно развиваются три экономические зоны (Казанская, Камская и формирующаяся Альметьевская) [1], в состав каждой входят городские агломерации, состоящие из центральных муниципальных образований, пояса агломерации и пояса формирующего влияния городских агломераций (пояса экономической зоны). В ССЭР РТ до 2030 года для каждой экономической зоны намечено чётное направление развития (сценарий). Казанская экономическая зона - территория развития «умной экономики», пространственное развитие ориентировано на поддержку перехода к пятому и в перспективе к шестому технологическому укладу.

Камская экономическая зона - лидер промышленно-технологического развития, территория «новой индустриализации» и развития высоких технологий. Планируется создание новых индустриальных проектов. Пространственное развитие Камской экономической зоны ориентировано на переход к пятому технологическому укладу с повышением плотности многоэтажной застройки, коренным улучшением экологических характеристик среды жизнедеятельности без расширения застроенных территорий за счет земель сельскохозяйственного назначения.

Перспективное видение Альметьевской экономической зоны - территория диверсификации экономики, модернизации нефтегазового комплекса на основе развития высоких технологий в области нефтедобычи и перехода к ее глубокой переработке, индустриализации сельскохозяйственных видов деятельности.

Пространственное развитие Альметьевской экономической зоны ориентировано на многоукладную диверсифицированную экономику.

Экономические интересы в развитии пространства доминируют в настоящее время и делают его, по мнению ряда учёных инновационно привлекательным. Конечно, концентрация производственных сил в Камской экономической зоне, а впоследствии и в Альметьевской обусловлена экономической выгодой (максимизация доходов, минимизация издержек) и это процесс объективный, но управление этим процессом носит субъективный характер. Ухудшение экологической ситуации, увеличение плотности населения, снижение уровня здоровья жителей, рост числа аварий происходит на фоне биосферно-социального кризиса.

В процессе дискуссий на данную тему на поверхность выплывает ряд вопросов по Камской экономической зоне: «Каким образом будет осуществляться обеспечение сохранности природных ресурсов и их баланс в текущем и будущем использовании с созданием новых индустриальных проектов и повышением плотности многоэтажной застройки? Как предполагается осуществить промышленно-технологическое развитие Камской зоны с коренным улучшением экологических характеристик среды 
жизнедеятельности без расширения застроенных территорий за счет земель сельскохозяйственного назначения?».

На сегодняшней день именно в Камской агломерации наиболее остро по сравнению с другими районами Татарстана стоит вопрос экологической чистоты территории, и вопрос дальнейшего индустриального развития не может не пугать население и не нарушать их баланс жизни.

В таблице 1 и на рисунке 1 представлены данные ежегодного доклада о состоянии санитарно-эпидемиологического благополучия населения в Республике Татарстан.

Таблий 1.

Показатели загрязнения атмосферного воздуха на 2015-2017 годы [3]

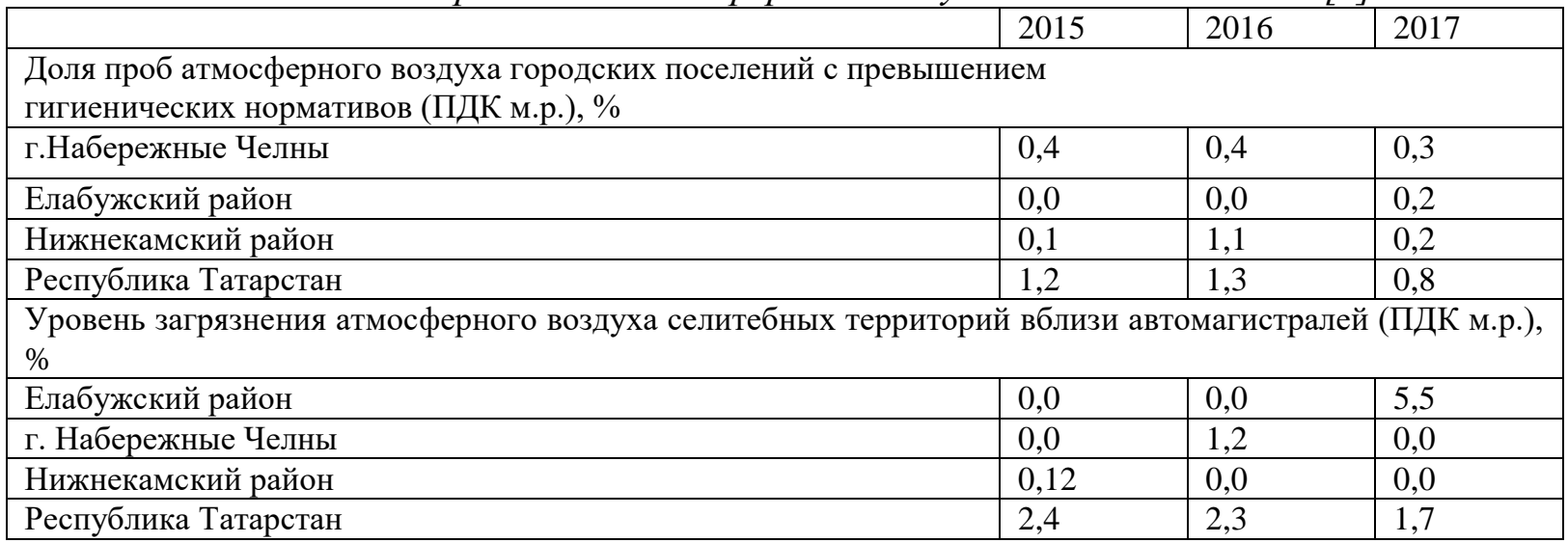

Как можно заметить все города входящие в таблицу 1 относятся к Камской экономической зоне. Рассмотрим долю выбросов вредных веществ в атмосферу в 2016 году, рисунок 1.

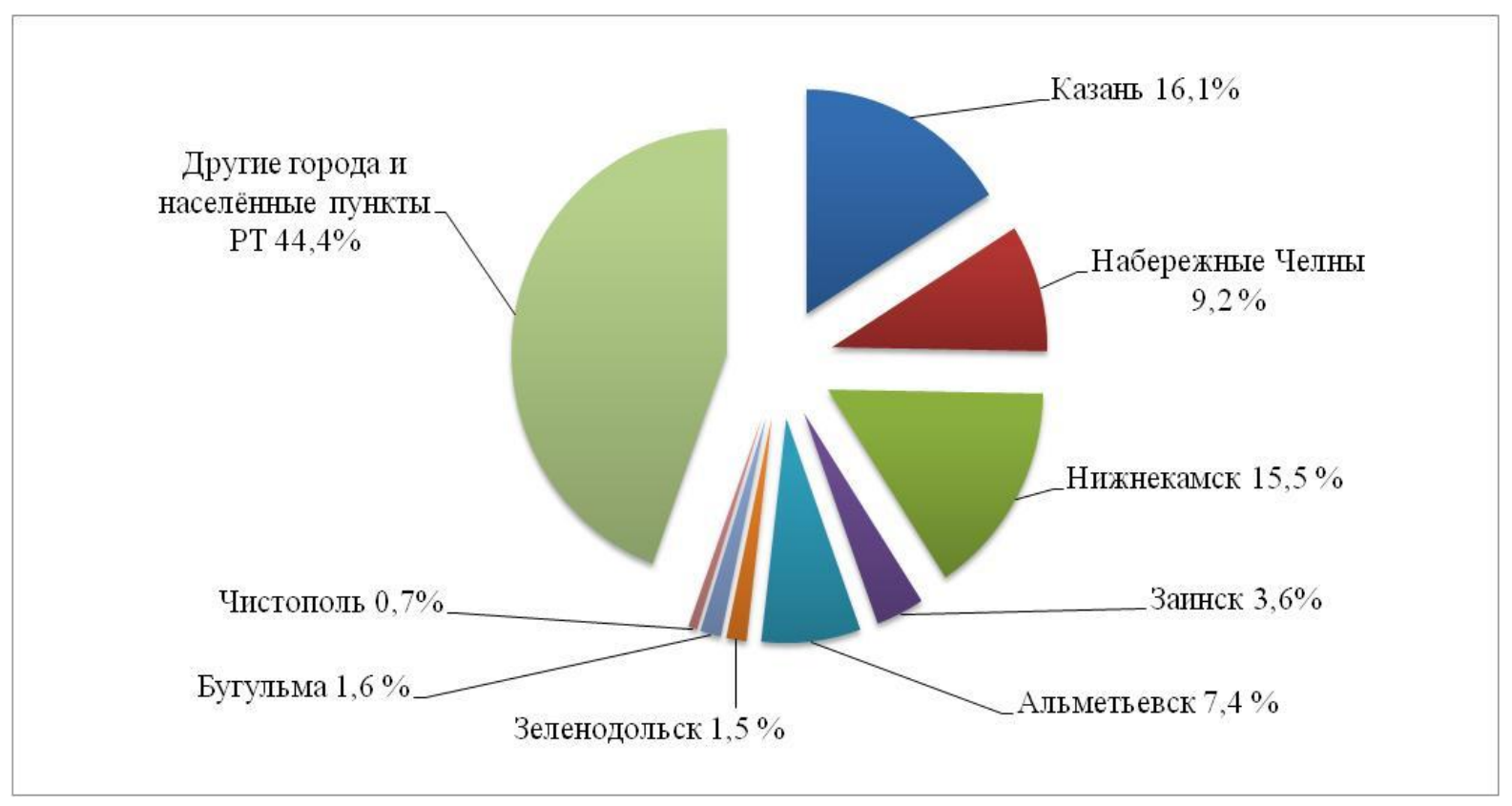

Рисунок 1. Доля выбросов вредных веществ в атмосферу по основным городам Республики Татарстан в 2016 2., $\%[3]$

Основная масса суммарных выбросов загрязняющих веществ от предприятий республики приходится на города: Казань, Нижнекамск, Набережные Челны, Альметьевск, Заинск, где расположено наибольшее количество промышленных объектов [3]. Два из перечисленных города Нижнекамск и Набережные Челны находятся в Камской экономиской зоне, а суммарная доля выбрасов по ним - 24,7\%. Произошло увеличение 
объёма выбросов вредных веществ в сравнении с 2015 годом по Набережным Челнам на $24,8 \%$, по Нижнекамску на 37,4\%, причём увеличение доли выбросов по республике произошло на 7,8\%.

Данное обстоятельство ещё раз подтверждает остроту проблемы -экологический кризис.

В 2017 году в Набережных Челнах на 15,8\% увеличилась доля проб почвы, не соответствующих гигиеническим нормативам по санитарно-химическим показателям, что выше показателя по Республике Татарстан на 14,4\%. Причины - аварии на канализационных сетях, увеличение количества образующихся твердых коммунальных отходов, возникновение несанкционированных свалок твердых коммунальных отходов.

Ухудшение экологической обстановки ведёт к росту заболеваний, наиболее критично обстоит дело с заболеваниями по злокачественным новообразованиям. Прирост показателя в 2016 году составил 3,1\%.

Уровень профессиональной заболеваемости в Республике Татарстан в 2017 году составил 1,85 на 10 тысяч работников, что выше среднемноголетних показателей на 0,2. $37,2 \%$ всех случаев профессиональных заболеваний зарегистрированы среди работников предприятий и организаций г.Набережные Челны, 28,6\% - среди работников г.Казани.

Таблииа 2.

Показатели профессиональной заболеваемости на отдельных предприятиях Республики Татарстан за 2015-2017 годы годы (на 10000 работников) [3]

\begin{tabular}{|c|c|c|c|}
\hline Наименование предприятия & 2015 & 2016 & 2017 \\
\hline Республика Татарстан & 1,8 & 1,3 & 1,85 \\
\hline \multicolumn{4}{|l|}{ г. Набережные Челны } \\
\hline Литейный завод ПАО «КАМАЗ» & 67,0 & 58,4 & 108,0 \\
\hline Ремонтно-инструментальный завод ПАО «КАМАЗ» & 6,4 & 6,4 & 32,0 \\
\hline Прессово-рамный завод ПАО «КАМАЗ» & 4,2 & 12,5 & 13,2 \\
\hline Автомобильный завод ПАО «КАМАЗ» & 9,3 & 8,0 & 8,7 \\
\hline \multicolumn{4}{|l|}{ г. Казань } \\
\hline АО «Казанское моторостроительное производственное объединение» & 18,1 & 19,8 & 40,0 \\
\hline ПАО «Казанский вертолётный заод» & 8,5 & 11,3 & 14,0 \\
\hline КАЗ им.С.П.Горбунова-филиал ПАО «Туполев» & 14,0 & 19,3 & 24,4 \\
\hline
\end{tabular}

На уровень профессиональной заболеваемости существенное влияние оказывают условия труда как один из основных факторов риска формирования профессиональной и профессионально обусловленной патологии. В настоящее время в Республике Татарстан сохраняются отрасли промышленности, где неудовлетворительные условия труда обуславливают высокий априорный риск развития профессиональных заболеваний.

Заболеваемость и распространенность психическими и поведенческими расстройствами в республике увеличилась на 8,1\% - с 207,0 на 100 тыс. населения в 2015 году до 223,7 на 100 тыс. населения в 2016 году. В структуре заболеваемости психическими расстройствами $67,4 \%$ составляют психические расстройства непсихотического характера, 23,7\%-психозы, на умственную отсталость приходится 8,8\% [3].

Говоря о принципе равновесия спомним, что на формирование городского пространства с позиции комфортного прожиаания существенно влияет степень озеленения территории.

Согласно п. 4.1. СНиП 2.07.01-89 «Градостроительство. Планировка и застройка городских и сельских поселений» уровень озелененности территории застройки должен быть не менее $40 \%$, а в границах территории жилого района - не менее $25 \%$ (включая суммарную площадь озелененной территории микрорайона).

В целом по Татарстану общая площадь зелёного фонда в городах республиканского подчинения составила на 01.01.2018 г. 38429 га. или 23,2\% от площади 
застройки. На рисунке 2 представлены данные по степени озеленения ряда городов Камской экономической зоны.

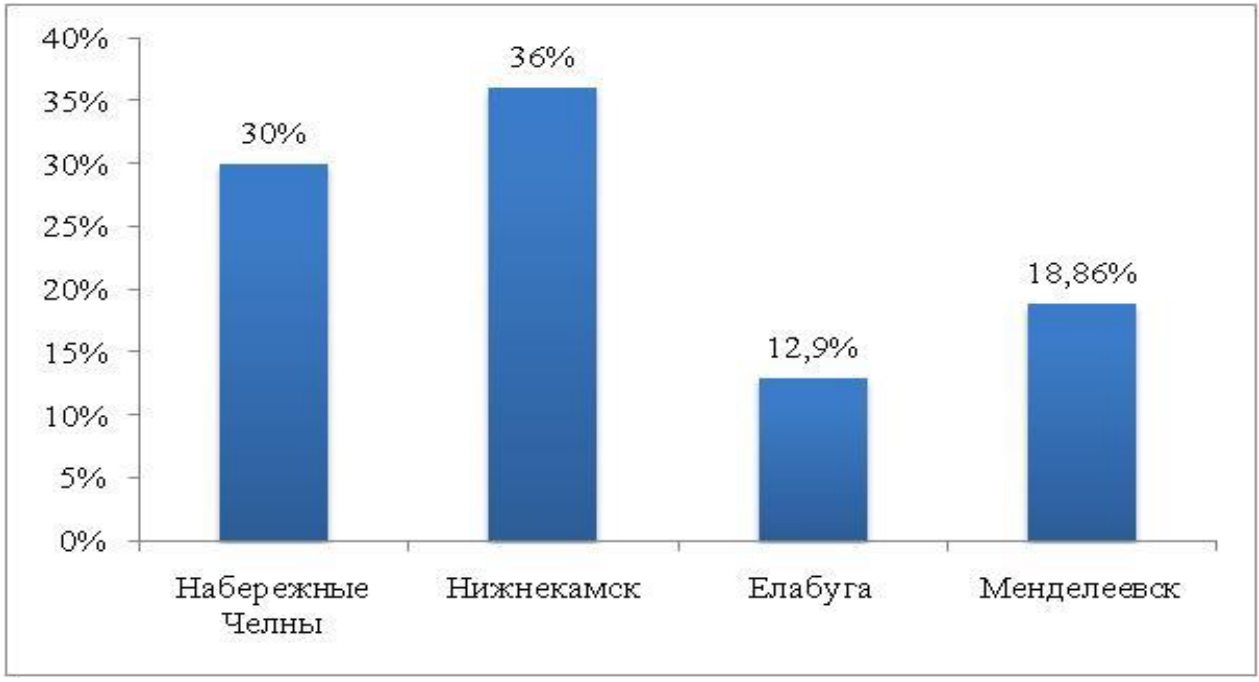

Рисунок 2. Степень озеленения городов Камской экономической зоны в \% от общей площсади города [5]

Необходимо отметить, что в республике активно ведётся работа по созданию зелелых насаждений общего пользования, в 2017 году создано 229,41 га, объём финансирования - 911435,3 руб.

В заключении отметим, что устойчивое сбалансированное развитие территории невозможно без соблюдения принципов пространственного развития, которые являются каркасом, аккумулирующим деятельность всех субъектов городского планирования в единый комплекс.

$$
\text { *** }
$$

1. Стратегия социально-экономического развития Республики Татарстан до 2030 года, принята Государственным Советом Республики Татарстан 10.06.2015 года.

2. Сандаковский П.А. Историческое наследие современной урбанизации и переход к ландшафтноусадебной урбанизации.URL: https://ecodelo.org/rossiyskaya_federaciya/42255istoricheskoe_nasledie_sovremennoy_urbanizacii_i_perehod_k_landshaftno. Дата обращения 12.08.2018 г.

3. Государственный доклад «О состоянии санитарно-эпидемиологического благополучия населения в Республике Татарстан» в 2017 году

4. Любова О.В., Ахмадеева О.А., Гузалёва С.Ю. Фундаментальные и прикладные аспекты современных экономико-правовых исследований коллективная монография в 3-х томах Том. 1. - Сер. Международный российско-израильский научно-издательский проект "ЗОЛОТАЯ МОНОГРАФИЧЕСКАЯ СЕРИЯ"

5. Государственный доклад «О состоянии природных ресурсов и об охране окружающей среды Республики Татарстан» в 2017 году 


\title{
РАЗДЕЛ VІ. ЮРИСПРУДЕНЦИЯ
}

\author{
Лавёрычева С.А. \\ Труд осужденных в следственном изоляторе: право или обязанность \\ ФКУ НИИ ФСИН России \\ (Россия, Москва)
}

doi: $10.18411 / \mathrm{j}-08-2018-42$

idsp: 000001:lj-08-2018-42

\section{Аннотация}

В статье анализируется ч. 1 ст. 103 Уголовно-исполнительного кодекса Российской Федерации с точки зрения соответствия ч. 2 ст. 37 Конституции России на примере работ по хозяйственному обслуживанию, выполняемых осужденными в следственном изоляторе.

Ключевые слова: Следственный изолятор, труд осужденных, работы по хозяйственному обслуживанию следственного изолятора.

Одним из основных средств исправления осужденных является общественно полезный труд. О воспитательной роли пенитенциарного труда неоднократно подчеркивалось в научных работах. В частности, И.В. Шмаров указывал, что «хозяйственно-производственная деятельность мест заключения должна быть подчинена основной задаче - исправлению и перевоспитанию преступников».

В связи с этим Уголовно-исполнительный кодекс РФ (далее - УИК РФ) закрепляет положение, согласно которому каждый осужденный к лишению свободы обязан трудиться в местах и на работах, определяемых администрацией исправительных учреждений (ст. 103 УИК РФ). Согласно российскому законодательству, учреждения, исполняющие наказания, с учетом трудоспособности и, по возможности, специальности привлекают осужденных к оплачиваемому труду: в центрах трудовой адаптации осужденных и производственных (трудовых) мастерских учреждений, исполняющих наказания; на федеральных государственных унитарных предприятиях уголовноисполнительной системы; на объектах организаций любых организационно-правовых форм, расположенных на территориях учреждений, исполняющих наказания, и вне их; по хозяйственному обслуживанию учреждений, исполняющих наказания, и следственных изоляторах.

Однако в науке указанное положение часто признается неконституционным, так как ч. 1 и ч. 2 ст. 37 Конституции России провозглашают, что «труд свободен», «принудительный труд запрещен». При этом каких-либо оговорок в отношении труда осужденных к лишению свободы в Конституции РФ не содержится.

В данном случае, с целью разрешения возникшего вопроса, представляется целесообразным обратиться к принципам и нормам международных нормативноправовых актов. Так, согласно п. «с» ч. 3 ст. 8 Международного пакта о гражданских и политических правах от 16 декабря 1966 г., термином «принудительный или обязательный труд» не охватываются «работа или служба, которую, как правило, должно выполнять лицо, находящееся в заключении на основании законного распоряжения суда». В Конвенции о защите прав человека и основных свобод от 4 ноября 1950 г. термин «принудительный или обязательный труд» также не включает в себя «всякую работу, которую обычно должно выполнять лицо, находящееся в заключении». В связи с чем труд 
осужденных, отбывающих уголовное наказание в местах лишения свободы, не представляется возможным признать принудительным или обязательным.

Однако с данной точки зрения заслуживает особого внимания труд осужденных, оставленных в следственном изоляторе (СИЗО) для выполнения работ по хозяйственному обслуживанию. Работы, выполняемые указанной категорией осужденных, направлены на обеспечение бесперебойного функционирования следственного изолятора и, по своей сути, являются обязательными.

В соответствии с законодательством Российской Федерации о труде, лица, оставленные в СИЗО для выполнения работ по хозяйственному обслуживанию, имеют право на оплату труда. Заработную плату они получают по ставке, на которую трудоустроены, поэтому для осужденного не имеет значение, какой объем работы он выполнит в конкретный период времени. В то же время не исключена возможность привлечения осужденных на работы со сдельной оплатой труда при проведении подрядчиком строительных работ на территории следственного изолятора, если в рамках договора между подрядчиком и администрацией следственного изолятора будет предусмотрено трудоиспользование осужденных.

Тем не менее при изучении вопросов оплаты трудовой деятельности в следственных изоляторах была выявлена одна особенность. У осужденных, отбывающих наказание в исправительной колонии общего режима и работающих на основном производстве, денежное вознаграждение значительно выше, чем у осужденных, занятых хозяйственным обслуживанием в следственных изоляторах.

Указанная особенность была отмечена рядом других авторов, по мнению которых «зарплату осужденных, выполняющих работы по хозяйственному обслуживанию следственных изоляторов, необходимо приравнять к заработной плате, предусмотренной для колоний общего режима и СИЗО, поскольку уголовно-исполнительный кодекс указывает на одинаковые условия отбывания наказания в этих учреждениях (ч. 3 ст. 77 УИК РФ)».

В связи с этим ряд авторов в своих научных работах предлагают произвести пересмотр расценок по оплате труда осужденных, оставленных в СИЗО для выполнения работ. Однако не стоит забывать о том, что осужденные по собственному желанию остаются в следственном изоляторе для отбывания уголовного наказания, поэтому порядок и условия труда для них вполне ожидаемы. Либо преследуемые личные интересы (условно-досрочное освобождение) при исполнении наказаний в СИЗО настолько велики, что осужденные готовы претерпеть возникающие при этом недочеты. Более того, выполняемая ими работа считается низкооплачиваемой не только в исправительных учреждениях, но и в условиях свободы.

При всем том выполнение работ предоставляет осужденным возможность зарабатывать себе денежные средства для приобретения предметов первой необходимости и продуктов питания, принимать меры по погашению иска (тем самым реализуя права потерпевших по уголовному делу), оказанию помощи родным, получению трудового стажа, накоплению небольшого капитала для первых дней после освобождения, а также получают перспективу освободиться условно-досрочно (при добросовестном выполнении работ).

Таким образом, труд осужденных в СИЗО нельзя отнести к их обязанности, поскольку они не лишены права перехода в исправительную колонию общего режима для дальнейшего отбывания наказания, изменив таким образом условия труда. Соответственно признать нарушенным конституционное право на свободный труд в 
отношении осужденных из отряда по хозяйственному обслуживанию не представляется возможным.

$$
* * *
$$

1. Закон РФ от 12 июля 1993 года «Об учреждениях и органах, исполняющих уголовные наказания в виде лишения свободы» [в ред. от 19.07.2018] // СПС «Гарант».

2. Баранов Ю.В., Нечаева Е.В. Проблемы организации труда осужденных в следственном изоляторе // Актуальные проблемы экономики и права. - Казань: Познание, 2008. - № 1 (5).

3. Шмаров И.В. О критериях оценки деятельности исправительно-трудовых учреждений по исправлению и перевоспитанию осужденных // Советское государство и право. - 1965. - № 3.

\section{Молчанова E.P. Чартер и коносамент: проформы, виды, особенности \\ Санкт-Петербургский филиал РТА (Россия, Санкт-Петербург)}

doi: $10.18411 / \mathrm{j}-08-2018-43$

idsp: 000001:lj-08-2018-43

\section{Аннотация}

В статье рассматриваются типовые проформы чартера и виды коносамента Ключевые слова проформы чартера, коносамент, оговорка в коносаменте

Договор морской перевозки груза, именуемый в зарубежной правовой литературе «contract for carriage of goods by sea» [1], это соглашение между отправителем и перевозчиком, определяющее условия перевозки груза из одного пункта моря в другой[2]. «Итогом длительных наработок стало создание типовых проформ чартеров всех типов. В настоящее время известно более 400 проформ чартеров. Они разработаны под эгидой старейших и авторитетнейших организаций - Английской палаты судоходства, основанной в 1877 году, и БИМКО (Балтийский международный морской совет)» [3], основанного в 1905 году.

Существуют проформы чартеров, предназначенные для перевозки угля, кокса, зерна, риса, арахиса, соли, фруктов, удобрений. «Для некоторых грузов разработано несколько проформ чартеров в зависимости от направления грузопотока» [4].

Перевозки грузов, для которых нет специальных проформ, как правило, осуществляются на базе чартера «Дженкон» («Gencon») [1].

Преимущество проформ чартеров заключается в том, что они учитывают интересы фрахтователей и фрахтовщиков. Большинство из таких чартеров представляют собой своего рода компромиссы, выработанные в результате длительных переговоров.

Применение проформ чартеров в значительной степени облегчает технику фрахтования судов. На практике условия чартера можно согласовать по телефону, факсу, телексу и через Интернет.

Чаще всего проформы чартеров состоят из двух частей - части первой, так называемой «боксовой» и части второй, содержащей собственно текст. «В боксовой части указываются условия, согласованные сторонами в ходе переговоров (количество груза, сроки перевозки, тип судна, порт погрузки-отгрузки). Во второй части указываются права и обязанности сторон, ответственность, а также иные условия, ставшие типовыми (например, субститут, диспач, реверсибл, канцеллинг и прочие). Чтобы исключить или изменить условия, предусмотренные второй частью проформы, стороны составляют аддендум (addendum)» [5]. Для удобства использования во всех рекомендованных проформах имеется нумерация строк, которая сохраняется неизменной независимо от издания проформы и языка, на котором она опубликована.

«Хотя фразеология некоторых стаей чартеров кажется архаичной и не совсем ясной, в судебной практике не встречается затруднений в их толковании, а сам факт наличия именно таких формулировок свидетельствует об их жизненности» [4]. 
«Коносамент (bill of lading) в большинстве случаев выдается в подтверждение приема груза к перевозке как тогда, когда груз перевозится на линейном судне, так и тогда, когда перевозка осуществляется на зафрахтованном в соответствии с чартером трамповом судне (в последнем случае коносамент может быть назван чартерным)» [2].

Линейный коносамент выполняет следующие основные функции: служит одним из документов, оформляющих договор перевозки груза в линейном судоходстве; служит распиской судовладельца в приеме груза к перевозке; является товарнораспорядительным документом, то есть таким документом, владение которым дает право его держателю распоряжаться грузом и требовать его выдачи в порту назначения.

Чартерный коносамент нельзя признать документом, оформляющим договор фрахтования, так как условия такого договора содержатся в другом документе - чартере. Две же другие указанные выше функции коносамента присущи ему и тогда, когда он является чартерным.

Помимо чартерного и линейного коносамента выделяют береговой и бортовой коносамент. Береговой коносамент выдается в подтверждение приема груза на берегу (как, правило на складе перевозчика). Если же груз погружен на судно, то подтверждением этого факта служит бортовой коносамент. Иногда береговой коносамент после погрузки заменяется на бортовой.

Выданный фрахтовщиком «коносамент свидетельствует о количестве принятого к перевозке груза, его внешнем виде и состоянии упаковки. Коносамент, в котором нет оговорок, ставящих под сомнение количество принятого к перевозке груза или указывающего на его ненадлежащее состояние или дефекты его упаковки, называется чистым коносаментом (clean bill of lading).

Однако, если внешнее состояние груза ли его упаковка вызывают сомнение в отношении сохранности груза, капитан вправе сделать соответствующую оговорку в коносаменте. Наличие такой оговорки, делающей коносамент «нечистым» (foul bill of lading), снижает доказательственную силу и значение коносамента как товарораспорядительного документа. Например, банк может не принять такой коносамент к обращению» [4].

$$
* * *
$$

1. Koppenol-Laforce M. «International contracts». London, 1996. C. 127, C.130.

2. Дмитриев В.Н., Дмитриева Е.Н., Латухов С.В. Правовое обеспечение профессиональной деятельности моряков. М.: ИКЦ Академкнига, 2006. С.158, 168.

3. Морозов С.Ю. Транспортное право: Учебное пособие. М.: Волтерс Клувер, 2009. С.221.

4. Гуцуляк В.Н. Морское право: учебное пособие. М.: РосКонсульт, 2003. С.325, С.326.

5. Борисенко И.И., Саенко В.В. Современный русско-английский юридический словарь. М.: РУССО, 2006. C. 12.

\section{Токарева К.Г. \\ О некоторых аспектах качества сферы бытового обслуживания}

Набережночелнинский филиал ЧОУ ВО «Казанский инноващионный университет им. В.Г. Тимирясова (ИЭУП)»

(Россия, Набережные Челны)

doi: $10.18411 / \mathrm{lj}-08-2018-44$

idsp: 000001:lj-08-2018-44

Основополагающим принципом работы организаций службы быта является создание удобств для населения. Организация бытового обслуживания (размещение пунктов бытового обслуживания, предлагаемые виды услуг, формы обслуживания населения) должна строиться применительно к условиям и распорядку жизни людей.

Сфера бытового обслуживания представляет собой совокупность определенных видов деятельности, функциональное значение которых выражается в оказании и реализации бытовых услуг для населения. Бытовое обслуживание населения призвано 
удовлетворять личные потребности людей, потребности, которые, как известно, непрерывно изменяются и развиваются. На сегодняшний день, когда по ряду видов бытовых услуг проблема количества в основном решена, потребитель все больше нуждается в повышении качества услуг и в формах обслуживания.

С экономической точки зрения качество бытовой услуги - это совокупность ее потребительских свойств, определяющих степень соответствия потребностям индивидуального потребителя при фиксированных затратах труда и средств на производство, реализацию и потребление услуги.

Р. Ристлаан считает, что под качеством бытовой услуги следует понимать совокупность ее потребительских свойств, которые могут быть выражены как в овеществленном виде, так и в виде непосредственной деятельности при обслуживании потребителя, определяющую степень ее соответствия потребностям конкретного индивидуального потребителя.

П.Я. Калита под качеством бытовой услуги понимает совокупность ее потребительских свойств, закрепленных нормативно-техническими документами и (или) индивидуальным договором между предприятием и заказчиком в установленном порядке.

В литературе и на практике используют понятия «качество бытовых услуг», «качество бытового обслуживания», «культура бытового обслуживания». Говоря о качестве, следует иметь в виду следующие его уровни: отдельное свойство, например, чистота обработки срезов деталей верха новой обуви или срок выполнения заказа; комплекс отдельных свойств, например, модель обуви; комплекс всех свойств, характеризующих функциональное назначение услуги, т.е. соответствие вещи (работы, услуги) требованиям нормативно-технической документации или заказчика; интегральное качество, т.е. качество вещи (работы, услуги) и процесса обслуживания потребителя.

Таким образом, неправомерно качество бытовых услуг сводить только к качеству отдельных изделий. В этом случае потребитель не получает полного удовлетворения, ибо процесс обслуживания отодвигается на второй план, а часто и вовсе остается вне поля зрения работников службы быта. Культура обслуживания - это неотъемлемая часть бытовой услуги. Услуга не может быть высококачественной, если не обеспечен соответствующий уровень обслуживания потребителя.

Под культурой обслуживания населения понимаются степень доступности услуги, обстоятельства, связанные с ее получением, т.е. совокупность условий, в которых она оказывается потребителю, организация приема, исполнения работ (услуг), степень учета индивидуальных запросов и требований потребителей. Имеются в виду этическая, эстетическая, организационная и правовая стороны взаимоотношений «мастер-заказчик».

Одним из важнейших элементов культуры обслуживания является создание необходимых удобств для населения на пункте бытового обслуживания (оборудование и эстетическое оформление помещения, удобство планировки, освещение и т.д.), а также хорошая информация потребителя услуг (реклама, справочно-диспетчерская служба и др.). Отсутствие случаев завышения прейскурантных цен, отказа выполнения сложных заказов, бесквитанционного выполнения работ, возврата на переделку и многое другое тоже элемент культуры обслуживания.

Качество в сфере бытового обслуживания отличается тем, что на него влияет целый комплекс дополнительных требований, в том числе затраты времени потребителя на получение (ожидание) услуги, сроки обслуживания, возможность потребителя выбрать способ обслуживания (торговая сеть, бытовое предприятие, услуги частных лиц, традиционное самообслуживание), степень удовлетворения спроса населения на услуги, освоение новых видов услуг и форм обслуживания, культура обслуживания.

В настоящее время ни один нормативный акт не содержит каких-либо прямых указаний относительно сроков выполнения заказов и ответственности исполнителя за их нарушение. Таким образом, целесообразной представляется разработка примерной 
шкалы максимальных временных затрат на оказание той или иной услуги с учетом специфики самой услуги.

Сегодня основой для создания нормативной базы, определяющей качество услуг на всех этапах ее формирования, является Общероссийский классификатор видов экономической деятельности (ОКВЭД2) ОК 029-2014.

В условиях рыночной экономики стандартизация становится одним из основных рычагов регулирования социальной и другой деятельности сферы услуг.

Действующий в настоящее время Закон РФ «О техническом регулировании», регламентирующий отношения обязательности и добровольности соблюдения показателей качества товаров и услуг, устанавливает для бытовых услуг обязательные требования.

Для бытовых услуг оценка качества осуществляется на двух уровнях управления: на уровне государства и на уровне исполнителя услуг.

На уровне государства основными нормативными документами, регулирующими уровень качества и безопасности услуг, являются: законы, правила бытового обслуживания, классификаторы услуг и видов деятельности, основополагающие государственные стандарты и государственные стандарты на виды бытовых услуг.

На уровне организации действуют наряду с нормативными документами государственного уровня документы, устанавливающие и конкретизирующие процесс производства услуги для этой организации. Как правило, это технические условия, стандарты предприятия, технологии, регламенты, руководства по ремонту и т.д.

Оценка качества и безопасности услуг на соответствие установленным нормам может производиться исполнителями услуг и потребителями услуг. Услуги, подлежащие обязательной сертификации, были определены постановлением Правительства Российской Федерации «Об утверждении перечня товаров, подлежащих обязательной сертификации, и перечня работ и услуг, подлежащих обязательной сертификации» и «Номенклатурой продукции и услуг (работ), подлежащих обязательной сертификации и Номенклатурой продукции, соответствие которой может быть подтверждено декларацией о соответствии». Данные нормативные акты устанавливали основные принципы обязательной сертификации услуг по техническому обслуживанию и ремонту автомототранспортных средств (далее - ТО и Р АМТС), организационную структуру Системы сертификации услуг по ТО и Р АМТС, а также порядок сертификации услуг по ТО и Р АМТС; и распространялись на легковые и грузовые автомобили, автобусы, специальные и специализированные автотранспортные средства, мототехнику и прицепной состав и их составные части. Однако указанные акты утратили силу с принятием постановления Правительства РФ «Об утверждении единого перечня продукции, подлежащей обязательной сертификации, и единого перечня продукции, подтверждение соответствия которой осуществляется в форме принятия декларации о соответствии», согласно которому к услугам, подлежащим обязательной сертификации, отнесены ремонт и техническое обслуживание бытовой радиоэлектронной аппаратуры, бытовых машин и бытовых приборов, химчистка и крашение, техобслуживание и ремонт автотранспортных средств, услуги парикмахерских, транспортные, жилищнокоммунальные, туристские и экскурсионные услуги, а также услуги торговли и общественного питания.

Сертификация рассматриваемого вида услуг производится по нескольким схемам:

схема 1 применяется, как правило, для небольших предприятий (1-5 человека в сфере основного производства), в которых ответственность за качество и безопасность оказания услуг (выполнение работ) в полном объеме возлагается на непосредственных исполнителей услуг (работ) и определяется их мастерством. Оценка оказания услуг осуществляется посредством оценки мастерства исполнителя работ и услуг, осуществляемой путем оценки возможностей конкретных работников исполнителя оказывать услугу (выполнять работу) в соответствии с установленными требованиями. 
Оценка мастерства исполнителя работ и услуг предусматривает проверку:

соответствия квалификации, опыта работы и иных профессиональных характеристик конкретных работников исполнителя требованиям, установленным в нормативных и технических документах;

оформленных в установленном порядке документов, подтверждающих опыт работы и профессиональные характеристики конкретных работников исполнителя (трудовая книжка, конкурсный диплом, производственная характеристика, свидетельство о присвоении разряда, удостоверение о прохождении специального обучения и т.п.);

знаний работниками технологической и нормативной документации, метрологического обеспечения производства; навыков оказания услуги (выполнения работы), в том числе использования при этом технологического оборудования и оснастки.

При этом в актах фиксируются установленные в результате проверок квалификационные, идентификационные и другие характеристики конкретных работников исполнителя (паспортные данные, сведения о квалификации, ответственность и т.п.), которые выступают в качестве условий действия сертификата соответствия. Помимо этого в состав условий могут входить: способы ремонта (технологии) или отдельные элементы технологического процесса; виды применяемого оборудования и средств измерений; марки (модели) автомототранспортных средств и др.

Схема 2 применяется при сертификации небольших и средних предприятий (от 5ти до 30-ти человек в сфере основного производства), имеющих двух-, трехуровневую структуру управления и распределения ответственности за качество и безопасность оказания услуг.

Оценка оказания услуг осуществляется посредством оценки процесса выполнения работ, оказания услуг, которая производится путем оценки возможностей исполнителя осуществлять конкретный процесс оказания услуги (выполнения работы) в соответствии с установленными требованиями.

Оценка процесса выполнения работ, оказания услуг предусматривает проверку:

обеспеченности процесса нормативными и техническими документами;

обеспеченности процесса необходимыми техническими средствами, оборудованием, оснасткой, средствами измерений (включая их поверку);

соответствия квалификации, опыта работы и иных профессиональных характеристик персонала требованиям, установленным в нормативных и технических документах.

При этом в актах фиксируются основные параметры оцениваемого процесса выполнения работ, оказания услуг, которые являются условиями действия сертификата соответствия. В качестве параметров могут выступать: способы ремонта (технологии) или отдельные элементы технологического процесса; виды применяемого оборудования и средств измерений; марки (модели) автомототранспортных средств; требования к квалификации, опыту работы, иным профессиональным характеристикам персонала и др.

Схема 3 применяется в большинстве случаев для крупных предприятий (с числом занятых в сфере основного производства более 30 человек), имеющих, как правило, многоуровневую структуру управления и распределения ответственности, использующих документально оформленные процессы оказания услуг (выполнения работ), а также располагающих организационно-техническими и кадровыми ресурсами для проектирования (корректирования) процесса оказания услуг (выполнения работ).

Оценка оказания услуг осуществляется посредством анализа состояния производства, осуществляемого путем оценки возможностей исполнителя стабильно проводить весь комплекс работ, связанных с оказанием услуги (выполнением работы) с учетом возможностей корректирования (проектирования) процесса оказания услуги (выполнения работы) или его отдельных элементов. 
При этом оценивается обеспеченность исполнителя должными процедурами, кадрами, способными осуществлять корректирование (проектирование) процесса оказания услуги или его отдельных элементов; процесс оказания услуг в соответствии с процедурами оценки процесса.

Для каждого конкретного кода услуги, установленного общероссийским классификатором услуг, определяется свой набор характеристик, подтверждаемых при сертификации.

Наряду с обязательной сертификацией в организациях сферы обслуживания применяются системы добровольной сертификации. При этом оценка проводится в основном по показателям организаций, где основными из них являются: качество самой услуги; организация и культура обслуживания; доступность услуги и приносимый услугой ущерб или эффект.

\section{$* * *$}

1. Калита П. Я. Роль стандартов в улучшении качества бытовых усллуг // Стандарты и качество. - 1977. № 8. - C. 72-76.

2. Нацыпаева Е.А., Давыдов Э.Р. Проблемы повышения качества обслу-живания в торговых организациях // Вестник Саратовского государственного социально-экономического университета. 2016. - № 5 (64). - C. 28-32.

3. Ристлаан Р. Пути повышения качества бытового обслуживания населе-ния. - Минск, 1976. - 182 с.

4. Смирнова А.А. Показатели качества бытового обслуживания // Наука XXI века. - 2017. - № 7. - С. 34 35.

\section{Токарева К.Г., Сейидова Е.P. \\ Ответственность сторон за неисполнение или ненадлежащее исполнение договора поставки}

Набережночелнинский филиал ЧОУ ВО «Казанский инновационный университет им. В.Г. Тимирясова (ИЭУП)»

doi: $10.18411 / \mathrm{j}-08-2018-45$

(Россия, Набережные Челны)

idsp: 000001:lj-08-2018-45

Своевременная поставка товаров надлежащего качества в количестве и ассортименте, предусмотренных договором поставки, и своевременная их оплата являются необходимыми условиями успешного развития экономики, рыночных отношений. Именно поэтому в ГК РФ подробно определены негативные последствия нарушения каждой из сторон своих обязательств, предусмотрены средства обеспечения реального исполнения договора и соблюдения прав и интересов стороны договора, добросовестно исполнившей обязательства. В соответствии с общими нормами обязательственного права каждая из сторон вправе требовать от другой стороны возмещения убытков, причиненных нарушением обязательств. Однако важное значение имеют и иные последствия, наступающие при нарушении договора: обязанность устранения нарушений, право одностороннего отказа от исполнения договора, уплата неустойки (штрафа, пени) и др.

Последствия нарушения поставщиком условий договора о количестве и сроках поставки предусмотрены ст. 511 ГК РФ. Согласно этой норме поставщик обязан реально выполнить договор, т.е. восполнить в натуре недопоставленное количество. Однако нарушение срока поставки (просрочка поставки) также может служить основанием для одностороннего отказа покупателя от принятия товаров, поставка которых просрочена. Другой случай нарушения поставщиком условий о сроке поставки - досрочная поставка без согласия покупателя - дает ему право отказаться от оплаты и принятия товаров, переданных досрочно. Принятые же покупателем досрочно поставленные товары засчитываются в счет количества товаров, подлежащих поставке в следующем периоде. 
Аналогичное нарушение покупателем условий договора о сроках и количестве, т.е. невыборка им товаров, вызывает иные последствия. Невыборка товаров покупателем (получателем) в установленные договором сроки и в количестве дает поставщику согласно ст. 515 ГК РФ право либо отказаться от исполнения договора в части поставки невыбранных товаров, либо предъявить к покупателю требование об их оплате. Несообщение же поставщиком покупателю о готовности товаров к передаче рассматривается в судебной практике как просрочка поставки со всеми вытекающими последствиями, т.е. покупатель вправе либо потребовать передачи товаров (восполнения недопоставленных товаров), либо отказаться от принятия товаров.

Нарушение условий договора об ассортименте товаров заключается в поставке товаров отдельных наименований в меньшем (недопоставка) или большем (перепоставка), чем предусматривалось договором, количестве. При недопоставке товаров одного наименования, входящего в ассортимент, покупатель вправе требовать восполнения недопоставки в следующем периоде независимо от того, отказался он или нет от товаров, поставленных с нарушением установленного договором ассортимента. Количество товаров одного ассортимента может быть зачтено в покрытие недопоставки товаров другого ассортимента лишь с согласия покупателя.

Последствия поставки товаров ненадлежащего качества предусмотрены ст. 475 ГК РФ. В соответствии с этой статьей покупатель в зависимости от характера недостатков вправе предъявить поставщику ряд требований. При обнаружении существенных недостатков, предусмотренных п. 2 ст. 475 ГК РФ, покупатель вправе отказаться от исполнения договора и потребовать возврата уплаченной суммы либо потребовать замены товара. В случае выявления иных недостатков покупателю предоставлено право потребовать от поставщика либо соразмерного уменьшения цены, либо безвозмездного устранения недостатков, либо возмещения своих расходов на устранение недостатков. Однако ст. 518 ГК РФ исключает применение упомянутых последствий передачи покупателю товаров ненадлежащего качества в случае, когда поставщик без промедления заменит поставленные товары товарами надлежащего качества, т.е. осуществит замену в такой короткий срок, который возможен при обязательствах конкретного случая. Этот срок исчисляется с момента получения уведомления (извещения) покупателя (получателя) о недостатках товаров, направленного в соответствии со ст. ст. 483 и 513 ГК РФ. При этом поставщику предоставлено право осуществить замену товаров без согласия покупателя.

Вместе с тем п. 2 ст. 518 ГК РФ предусматривает случаи, когда поставщик обязан заменить товар по требованию покупателя независимо от характера недостатков. Такое требование вправе заявить покупатель, осуществляющий продажу товаров в розницу, при условии, что товар с недостатками возвращен потребителем. Эта норма учитывает более широкие права покупателя-гражданина по договору розничной купли-продажи, предусмотренные ст. 503 ГК РФ. Она направлена на обеспечение прав граждан и гарантирует реальность требования о замене проданного недоброкачественного товара на доброкачественный. Поставщик обязан выполнить требование покупателя в натуре в разумный срок. Замена товара не освобождает его от возмещения убытков, понесенных покупателем.

Последствия нарушения поставщиком комплектности или передачи товара с нарушением согласованного комплекта товаров предусмотрены ст. 480 ГК РФ. Но они не наступают при замене поставщиком некомплектного товара комплектным или при доукомплектовании товаров. Аналогично норме, предусмотренной ст. 518 ГК РФ, замена или укомплектование товаров должны быть произведены по инициативе поставщика в кратчайший срок, исчисляемый с момента направления покупателем уведомления об отступлении от требований комплектности или условий о поставке комплекта товаров. 
При незамедлительных замене или укомплектовании поставщиком товаров покупатель (получатель) не вправе предъявить требования, предусмотренные ст. 480 ГК РФ, кроме требования о возмещении убытков.

Применение перечисленных последствий нарушения поставщиком условий договора о количестве, качестве, комплектности, ассортименте товаров и сроках поставки не всегда обеспечивает выполнение обязательства поставки в натуре. Поэтому в ГК РФ введена неизвестная ранее законодательству о договоре поставки норма, предоставляющая покупателю право в случае неисполнения поставщиком обязательств приобрести товары у других лиц.

В рыночных условиях покупатель получил не только право, но и реальную возможность приобрести товары у других лиц при нарушении поставщиком обязанности передать товары в обусловленный срок либо заменить товары, переданные с недостатками, товарами надлежащего качества или комплектными.

В соответствии со ст. 520 ГК РФ такое право возникает у покупателя при:

1) передаче поставщиком товаров в меньшем количестве, чем предусмотрено договором, или с нарушением сроков;

2) невыполнении поставщиком требования покупателя о замене недоброкачественных товаров на товары надлежащего качества;

3) неукомплектовании поставщиком товаров по требованию покупателя.

Все необходимые и разумные расходы по приобретению товаров у других лиц покупатель вправе взыскать с поставщика наряду с предъявлением требования о возмещении иных возможных убытков.

Покупателю товаров в случае поставки недоброкачественных или некомплектных товаров предоставлено также право отказаться от оплаты товаров, не соответствующих условиям договора о качестве и комплектности, а если товар уже оплачен, потребовать возврата уплаченных сумм до устранения недостатков. Таким правом покупатель может воспользоваться в том случае, когда он не отказывается от исполнения договора, а лишь требует замены товаров с недостатками товарами надлежащего качества или их доукомплектования. Правом отказа от оплаты товара покупатель может воспользоваться также, если договором предусмотрена оплата товаров через определенный срок после их передачи или оговорена рассрочка платежа, а также в иных случаях, когда несоответствие товаров условиям договора установлено покупателем до наступления срока их оплаты.

ГК РФ содержит норму, устанавливающую порядок взыскания неустойки за недопоставку и просрочку поставки товаров. В ст. 521 ГК РФ воспроизведен известный ранее действовавшему законодательству о поставках и практике принцип суммированного обязательства, согласно которому обязательство поставки товаров в каждом периоде поставки складывается из обязательства данного периода и обязательства по восполнению недопоставленного в предыдущем периоде количества товаров. При этом уплата поставщиком неустойки за невыполнение обязанности по передаче товаров в установленный договором срок не освобождает его от обязанности восполнения недопоставленного количества в натуре в следующем периоде либо в иные сроки, предусмотренные договором.

В этом случае в соответствии со ст. 521 ГК РФ неустойка взыскивается вторично со стоимости недопоставленных в предыдущем периоде товаров, если они не переданы покупателю в следующем периоде, так как количество товаров, не переданное покупателю в предыдущем периоде, прибавляется к количеству товаров, которые должны быть переданы в следующем периоде (в следующий частный срок), и со стоимости этого суммарного количества товаров при невыполнении обязательства начисляется неустойка.

Таким образом, неустойка взыскивается до фактического исполнения обязательства в пределах срока действия договора, если иное им не предусмотрено.

Ряд последствий установлен ГК РФ при нарушении покупателем условий об оплате поставленных товаров. Прежде всего, следует назвать право поставщика 
приостановить передачу подлежащих поставке товаров до полной оплаты ранее поставленных товаров (п. 5 ст. 486 ГК РФ). Это новое для договора поставки правило дает поставщику возможность, не отказываясь от исполнения договора, приостановить исполнение. При нарушении покупателем условий договора поставки о порядке и сроках расчетов применяются последствия, установленные общими положениями о куплепродаже (ст. ст. 486-489 ГК РФ), а также уплата процентов, предусмотренных ст. 395 ГК РФ.

Еще одно правовое последствие предусмотрено ст. 523 ГК РФ на случай неоднократного нарушения покупателем сроков оплаты товаров. По этому основанию поставщик вправе односторонне полностью или частично отказаться от исполнения договора.

Право выбора способа защиты своих законных интересов, нарушенных неоплатой или задержкой оплаты товара, предоставлено поставщику.

Кроме того, в силу ст. 15 ГК РФ лицо, право которого нарушено, может требовать полного возмещения причиненных ему убытков, если законом или договором не предусмотрено возмещение убытков в меньшем размере. Если же лицо, нарушившее право, получило вследствие этого доходы, лицо, право которого нарушено, вправе требовать возмещения наряду с другими убытками упущенной выгоды в размере не меньшем, чем такие доходы.

Таким образом, из изложенного выше можно сделать вывод, что договором поставки можно предусмотреть ответственность сторон в виде возмещения убытков, причиненных неисполнением или ненадлежащим исполнением обязательств, а также размера неустойки (штрафа, пеней) в случае неисполнения или ненадлежащего исполнения обязательств по договору.

$$
* * *
$$

1. Алмаева Ю.О., Токарева К.Г. Предпринимательское право. Учебное пособие. - М.: Юстиция, 2017. $218 \mathrm{c}$.

2. Золотухина О.В. Ответственность сторон по договору поставки // Наука в XXI веке: инновационный потенциал развития: Сборник статей по материалам V международной научно-практической конференции. - Уфа, 2017. - С. 54-65.

3. Иванов Н.В. Ответственность за нарушение обязательств по договору поставки в гражданском праве // Современные проблемы науки и образования. - 2014. - № 6. - С. 1723.

4. Михайлова А.В. Некоторые вопросы одностороннего отказа от договора поставки, в связи с существенными нарушениями договора // Новая наука: От идеи к результату. - 2016. - № 11-3. - С. $173-176$. 


\section{РАЗДЕЛ VІІ. ФИЛОЛОГИЯ}

\section{Буров А.А.. Куимов Р.Н. \\ К вопросу о структурации идиостиля автора прозаического текста}

ФГБОУ ВО «Пятигорский государственный университет»

(Россия, Пятигорск)

doi: $10.18411 / \mathrm{j}-08-2018-46$

idsp: 000001:lj-08-2018-46

\section{Аннотация}

В статье рассматриваются некоторые неизученные аспекты структурации идиостилевого пространства прозаического текста. Опираясь на данные современной лингвостилистики, теории языковой личности и теории синтаксической номинации, авторы приходят к выводу, что структуру идиостиля выдающегося современного русского писателя В.В. Орлова, автора трилогии «Останкинские истории», определяет употребление производных номинационно-синтаксического семиозиса, которые формируются в тексте в процессе усложнения внутренней формы наименования фрагментов авторской картины мира. Это способствует идиостилевой интимизации нарратива, регулирующей динамическое равновесие реального и фантастического планов орловского дискурса.

Ключевые слова: автор, нарратив, идиостиль, художественная картина мира, языковая личность, номинационно-синтаксический семиозис.

В последние годы лингвистика, в том числе русистика, испытывает очевидный дефицит исследований в области стилистики языковой личности автора художественного текста. Становится очевидным, что с завершением эпохи блестящего изучения языка русской литературы в фундаментальных трудах М.Н. Бахтина, В.В. Виноградова, Г.О. Винокура, А.И. Ефимова, Ю.М. Лотмана, Б.В. Томашевского и многих других ученых интерес к изучению индивидуального стиля отдельного автора заметно ослабел. Между тем специфика авторской индивидуальности, лежащей в основе идиостиля художника русского слова, на наш взгляд, немыслима как без изучения той загадочной славянской души, которая воплощена в литературно-художественном дискурсе [см., например: 15 и др.], так и вне постижения языковой идентичности, заметно влияющего на позитивное сдерживание тенденций к деструкции русского литературного языка (псевдодемократизация, варваризация, жаргонизация и т.д.).

Для лингвостилистики художественного текста принципиальным является конструктивно-стилевой вектор «беллетристикум», связанный, по мнению В.Г. Костомарова, с воплощением образа автора как осознанием «в себе то ли сознанием, то ли ощущением строя образов, мыслей, чувств, звуков в такой связи, в какой они до того не связывались никем (курсив наш - А.Б., Р.К.). Это позволяет писателю вскрыть правду о мире, показав его через самопознание в новом виде, посмотрев на него с новой, личностно-индивидуальной, «авторской» точки зрения» [9, с.107-108]. Особый «строй образов, мыслей, чувств, звуков» и есть то «рациональное зерно», которое, на наш взгляд, мотивирует постановку вопроса о структурации авторского идиостиля. Путь индивидуального конструирования текстового пространства - это способ уникального воплощения языковой личности автора.

Структурирование авторского идиостиля предполагает выявление наиболее показательных для данного художника слова языковых черт его авторской манеры письма, которая делает текст непохожим на аналогичные явления творчества.

Представляется актуальным исследование в указанном направлении индивидуальной манеры письма выдающегося русского писателя второй половины XX начала XXI веков Владимира Викторовича Орлова (1936 -2014), чей цикл «Останкинские 
истории» (романы «Альтист Данилов», «Аптекарь», «Шеврикука, или Любовь к привидению») занимает видное место в пространстве современной русской художественной прозы [10].

Лингвостилистика орловского текста практически не исследована в отечественной и зарубежной филологии. Сказанное относится в первую очередь к антропогенному ракурсу языковой личности автора, раскрывающему тезис «о человеке, стоящем во главе языковой картины мира, ее организующем и оценивающем» [16, с. 38]. Авторская языковая индивидуальность, между тем, не только формирует художественноэстетическое пространство текста и денотативную и образную его топику и атрибутику, но и осуществляет структурирование на всех уровнях текста - от формирования абзаца до номинационно-синтаксического членения, в котором реализуются авторские интенции обозначения фрагментов и отрезков художественной картины мира [3; 4 и др.].

За исключением единичных научно-исследовательских работ [ср.: 12; 5 и др.], лингвостилистика текста В.В. Орлова фактически еще вообе не изучена, не говоря уже об анализе структуры идиостиля писателя. Между тем имеются все основания для постановки и решения проблемы изучения «строя образов, мыслей, чувств, звуков» орловского текста.

В языке и стиле фактура романов, входящих в «Останкинские истории», динамически уравновешены взаимоисключающие друг друга реалистический и фантастический планы представления картины мира, и это динамическое равновесие регулируется за счет индивидуально-авторского подхода к структурации повествования. Поэтому для адекватного исследования орловского идиостиля могут быть использованы данные ряда современных лингвистических направлений, теорий и концепций, входящих в антропоцентрическую научно-исследовательскую парадигму.

Прежде всего это теория языковой личности (лингвоперсонология). развивающая мысли В.В. Виноградова о категории автора художественного текста как языковой личности - текстового воплощения человеческой индивидуальности (персона) на трех уровнях: а/ собственно вербальном, б/ когнитивном и в/ прагматическом [8; 7 и др.]. В языковой личности, по мнению исследователей, отражается образ человека, формирующийся на основании данных языковой (наивной) картины мира [1 и др.], которая имеет лингвокультурную модель [6 6 и др.], в том числе собственно художественно-литературного плана [11 и др.]. Языковая личность рассматривается и в других ракурсах: как выражение полилектного и диалектного начал или как представление этносемантического начала; на уровне проявления речевой элитарности; в качестве аналога лингвопрагматического «преемника» традиционного образа автора; как отражение национального начала; как соотношение языкового и речевого уровней языка; как выражение гендерных различий, как объект речевого портретирования; как явление уровня проявления эмоциональности говорящего и т.д. [2; 13; 4; 5; 14; 15 и др.].

В парадигме текстов романов В.В. Орлова, исследуемых в контексте современных научных представлений об авторе как языковой личности и структуре его идиостиля, вызывают несомненный интерес языковые средства и способы их употребления, позволяющие автору вскрыть идиостилевой потенциал репрезентации субъективных интенций в процессе структурирования текста, которое отражает индивидуальное познание художественной картины мира. Исследование орловского текста в данном ракурсе позволит сконцентрироваться на следующих локусах: 1/ идиостиль автора художественного текста как языковой личности, характеризующейся лингвокогнитивными и лингвопрагматическими особенностями; 2/ структурное пространство идиостиля языковой личности автора прозаического текста и способы репрезентации данной структуры - вообще и применительно к тексту В.В. Орлова; 3/особенности идиостилевого портретирования и автопортретирования языковой личности автора «Останкинских историй»; 4/ потенциал номинационносинтаксичечского семиозиса как одного из важнейших способов раскрытия авторской индивидуальности В.В.Орлова; 5/номинационно-синтаксический подход к структурации 
авторского идиостиля, способствующий раскрытию сложной внутренней формы номинации и др.

Антропогенный подход к структурации авторского идиостиля опирается на ряд современных лингвистических концепций. Это теория языковой личности и лингвоперсонологии и ее «рациональное зерно» - трехуровневая стратификация авторской индивидуальности: семиотика, когниция, прагматика; концепция идиостиля автора художественного текста, опирающаяся на фундаментальные структурносемиотические и функционально-прагматические данные стилистики и филологической интерпретации текста; теория синтаксической номинации и номинационносинтаксического семиозиса, ориентирующая исследователя на выявление индивидуально ощущаемых и присущих данному художнику слова приемов структурации текста и его метатекстовых образований. Все это позволяет реализовать принцип динамического подхода к языковым фактам и не только уточнить выделение структурных единиц художественного текста, но и определить индивидуально-авторские особенности их проявления в конкретном авторском идиостиле, в нашем случае - в тексте В.В. Орлова.

Попытка структурировать авторский идиостиль с учетом языковых данных личностного портретирования и автопортретирования позволяет сделать вывод: идиостиль художника слова основан на структурации пространства текста, когда реализуются авторские интенции, связанные с выражением явных и скрытых смыслов. В основе структурирования лежит принцип номинационно-синтаксического семиозиса, позволяющий проследить авторский подход к выделению фрагментов художественной картины мира и реализации индивидуально ощущаемых, имманентных изобразительных интенций [13 и др.]. Данные номинационно-синтаксического семиозиса текстового пространства, закрепляющие авторское имманентное представление о фрагментах картины мира в структурпации текстовых отрезков, позволяют фиксировать глубинные личностные смыслы.

Специфика структурного пространства идиостиля авторской индивидуальности современного русского писателя В.В. Орлова определяется синтезом субъективной индивидуализации фрагментов картины мира и стремления выразить в языковом знаке их сложную природу. Среди основных языковых средств выражения авторской индивидуальности и способов композиционной организации идиостиля данного автора выделяются номинационно-синтаксический словарь текста, соотношение диалогических и монологических форм высказывания, авторский метатекст как средство раскрытия подтекста в прозе писателя, специфическая организация и композиция абзаца и др. Одним из специфических речевых средств портретирования в тексте В.В. Орлова выступает фразовая номинация, способствующая раскрытию языковой личности художника слова в тексте [4; 13 и др.].

Структура авторского портрета (автопортрета), являющаяся одним из наиболее ярких признаков специфики идиостиля В.В. Орлова, опирается на номинационносинтаксический подход к членению текста, свидетельствуя о тенденции к усложнению внутренней формы номинации в языке современной русской художественной литературы. Основу идиостилевого портретирования языковой личности автора художественного (прозаического) текста образует структурация индивидуальной авторской картины мира, имеющая многоуровневый характер и на основе номинационносинтаксического семиозиса интегрирующая такие категории, как действительность, языковая личность, словарь, текст и метатекст и др.

Показателен контекст, которым начинается роман В.В. Орлова «Аптекарь»:

«Их развели.

- Платить-то будешь? - спросила Мадам.

- У матросов нет вопросов, - ответил Михаил Никифорович.

Это было лет пять назад, до нашего знакомства с Михаилом Никифоровичем. Заявление написал он. Теперь он темнит, уверяя, что текст заявления не помнит. Мол, что-то там такое было, что вот, мол, от меня ждут аристократических детей, а я, 
мол, рабоче-крестьянского происхождения, и потому, чтобы дальнейших огорчений не было, прошу развести. Мол, там посмеялись, но недолго, и развели.

В пивном автомате на улице Королева Михаила Никифоровича называли и Михаилом Никифоровичем, и Мишей, и Мишкой, и Аптекарем, и Лысыл, и Дипломатом, все вспоминать скучно» $[10$, с. 541].

Данная заставка к основному тексту произведения содержит обширный материал для составления лингвистического портрета героя, а с ним - и самого автора. Это: а) речевая характеристика - реплика первого знакомства: «У матросов нет вопросов» как синоним коммуникатива с семантикой согласия (да, конечно, обязательно); б) употребление частицы «мол» в косвенно-прямой форме речи: «Мол, что-то там такое было, что вот, мол, от меня ждут аристократических детей...»; в) клички («никнеймы») Михаила Никифоровича, которые были закреплены за ним в пивном автомате и характеризовали его как простого демократичного человека, однако имевшего интересную жизненную судьбу; г) дейктическая фиксация присутствия автора в процессе портретирования героя в реальном времени («до нашего знакомства»; «теперь он темнит»). Уже на основании этих данных можно начать формирование лингвистического портрета героя орловского романа.

Фрагменты индивидуальной картины мира проецируются в текстовых отрезках, которые являются производными номинационно-синтаксического семиозиса. Обладая художественной пространственностью, они позволяют автору «Останкинских историй» синтезировать в одном целом реальное и фантастическое, бытовой юмор и иронию, лиризм и приземленность, узнаваемость фантастических деталей. Все это представлено в ракурсе индивидуально-авторской интимизации идиостиля, что и фиксируется в текстовой структуре.

$$
* * *
$$

1. Апресян Ю.Д. Образ человека по данным языка: попытка системного описания // Вопросы языкознания. - 1995. - № 1. - С. 15-26.

2. Арутюнова Н.Д. Язык и мир человека. - М.: Языки русской культуры, 1998. - 436 с.

3. Буров А.А. Когниолингвистические вариации на тему русской языковой картины мира. - Пятигорск: Изд-во ПГЛУ, 2003. - 361 с.

4. Буров А.А. Субстантивная синтаксическая номинация в русском языке. - Ставрополь; Пятигорск: Издво СГУ, 2012. -400 c.

5. Буров А.А. Заметки об идиостиле современного русского писателя В.В. Орлова // Вестник ПГЛУ. 2015. - № 3. - С. 188-194.

6. Воробьев В.В. Лингвокультурология (теория и методы). - М.: Наследие, 1997. - 331 с.

7. Голев Н.Д. Языковая личность, антроподтекст и лингвоперсонологическая гипотеза языка // Филология XXI. - Барнаул: Изд-во БГПУ, 2004. - С. 4-9.

8. Караулов Ю.Н. Русский язык и языковая личность. Изд. 2-ое. - М.: Едиториал УРСС, 2002. - 264

9. Костомаров, В.Г. Наш язык в действии: Очерки современной русской стилистики / В.Г. Костомаров. М.: Гардарики, 2005. $-287 \mathrm{c}$.

10. Орлов В.В. Останкинские истории: сборник. - М.: Астрель, АСТ, - 2011. - 1502 с.

11. Петрова Л.А. Лингвокогнитивные основы художественной картины мира. - Симферополь: ОАО «СГТ», 2006. $-283 \mathrm{c}$.

12. Суханова И.А. Лексико-семантический анализ интертекста (на материале романа Владимира Орлова "Альтист Данилов") //Ярославский педагогический вестник. - 2001. - № 2. - С.52-57.

13. Фрикке Я.А. Фразовая номинация как средство выражения языковой личности автора художественного текста. - Пятигорск: Изд-во ПГЛУ, 2004. - 212 с.

14. Хачмафова 3.Р. Женская языковая личность в художественном тексте. Автореф. дис. ... д-ра филол. наук: 10.02.19. - Ставрополь, 2011. -45 с.

15. Чумак-Жунь И.И. Дискурсивное пространство поэтического текста: образное слово в русской лирике конца XVIII - начала XXI веков. Дис. ... д-ра филол. наук: 10.02.01. - Белгород, 2009. - 407 с.

16. Шведова Н.Ю. Местоимение и смысл. Класс русских местоимений и открываемые ими смысловые пространства. - М.: Азбуковник, 1998. - 176 с. 


\section{Горшунов Ю.В. \\ Ре-интерпретация структуры слова в популярных английских детских шутках и загадках}

Башкирский государственный университет (Бирский филиал) (Россия, Бирск)

doi: $10.18411 / \mathrm{j}-08-2018-47$

idsp: 000001:lj-08-2018-47

\section{Аннотация}

В данной статье рассмотрены им некоторые шутливые популярные детские вопросы-загадки, понимание которых сопряжено с переосмыслением структуры слов, положенных в основу ответа.

Ключевые слова: шутки, загадки, реинтерпретация структуры

\section{Abstract}

The article focuses on some popular English children's riddles in the question-answer form that are based on the new reading of the word-structure and presuppose morphological restructuring or structural re-interpretation of familiar words.

Key words: jokes, riddles, structure re-interpretation

В статье рассмотрим некоторые шутливые вопросы-загадки, взятые выборочно из сборника “The Schoolkids' Joke Book" [2], понимание которых сопряжено с переосмыслением структуры слов, положенных в основу ответа. Шутки и загадки подслушаны или записаны на игровых площадках и школьных аудиториях. Они отражают детское словотворчество, способность к языковой игре и способность детей увидеть комичное в нашей жизни.

Ниже приведенные шутливые вопросы-загадки построены на новом прочтении структуры слова, предполагают морфологическое переразложение слова или структурную ре-интерпретацию, например,

- What is a vampire's favourite food? Ответ: Neck-tarines.

По суеверным представлениям, вампир - это оборотень, мертвец, выходящий ночью из могилы или являющийся в облике летучей мыши, сосущий кровь у спящих людей, насылающий кошмары; вурдалак, упырь. Любимое блюдо вампиров, согласно загадке, - нектарины - сладкий и сочный фрукт, который не случайно считают одним из самых вкусных плодов на земле. Вампиры пьют кровь из шеи (neck), уязвимого места на теле человека. В слове nectarine первые три буквы nec совпадают по звучанию со словом neck, что позволило в юмористических целях разложить его на части и представить как Neck-tarine. Языковая игра здесь, выражаемая в расчленении слова на две части, сопровождается на письме графическим выделением - написанием через дефис.

- What skeleton was Emperor of France? Ответ: Napoleon Bone-apart.

В данной шутке-загадке обыгрывается полное имя французского императора Наполеона Бонапарта (Napoleon Bonaparte), одного из самых известных исторических деятелей и лучших полководцев в истории, творца государственных режимов многих стран Европы. Целая эпоха названа его именем, а его деяния стали потрясением для большинства современников. Благодаря отличительным особенностям во внешности и манере поведения Наполеон является узнаваемым культурным персонажем. Поражение при Ватерлоо вынудило Наполеона вторично отречься от престола. Свои последние годы он прожил на острове Святой Елены в плену у англичан. Известно, что Наполеон нелестно отозвался об Англии как о стране лавочников. Для английских карикатуристов Наполеон был излюбленным персонажем - в ранние годы тощим (англ. 
Boney - «худой», «тощий», «кожа да кости», «костлявый»), а в поздние толстым (англ. Fleshy) коротышкой-выскочкой. Ему дали кличку Boney, усиленную эпитетом bloody bloody Boney. Таким образом, имя Bonaparte обыгрывалось как Boney. Отголоски прозвища ассоциативно связаны с загадкой: имя Bonaparte трансформируется в Boneapart, оправдывая смысл загадки. Оба слова - имя Bonaparte и его трансформ произносятся одинаково, т.е. являются омофонами.

- What do you call a dog with a bunch of daisies on its head? Ответ: A collieflower. В загадке обыгрывается название овоща - cauliflower - цветная капуста и название породы собак - collie - колли, шотландская овчарка. В результтате получено необычное слово collie-flower.

Довольно часто структурная ре-интерпретация сопровождается заменой какоголибо (часто начального) компонента для создания комического эффекта, например,

- Who speaks at a ghosts' conference? Ответ: A spooksman. Отсылка к spokesman - оратор (от группы лиц). Spook infml for ghost [3, с. 1307].

- What nuts can be found in space? Ответ: Astronuts. Отсылка к слову astronaut - астронавт, космонавт (a person who travels in a spacecraft) [3,c. 64]. и замена компонента naut на nut.

- What wobbles when it flies? Ответ: A jellycopter.

Слово построено по аналогии с helicopter с заменой компонента heli на созвучное jelly и может быть проинтепретировано как helicopter made of jelly.

На лицо все признаки языковой игры, если считать, что языковая игра, как и комическое в целом, - это четко осознаваемое отступление от нормы, нечто необычное [1]. Рассмотрнные в статье случаи переосмысления структуры слов, положенных в основу ответа детских загадок можно охарактеризовать как детское словотворчество, проявление способности к языковой игре, лингвистическому эксперименту, и способности детей увидеть комичное в нашей жизни.

$$
* * *
$$

1. Санников В. 3. Русский язык в зеркале языковой игры. - М.: Языки русской культуры, 1999. - 543с.

2. Brough Girling. The Schoolkids' Joke Book. Collins, 1988. - 126p.

3. Longman Dictionary of English Language and Culture. New edition, 1998. 1568p.

\section{Горшунов Ю.В. \\ Ономатопея в популярных детских шутках, анекдотах и загадках}

Баикирский государственный университет (Бирский филиал) (Россия, Бирск)

doi: $10.18411 / \mathrm{j}-08-2018-48$

idsp: 000001:lj-08-2018-48

\section{Аннотация}

В данной статье рассмотрены занимательные случаи детских шуток, анекдотов и загадок, насыщенных звукоподражательными словами. Шутки и загадки заимствованы из сборника детского фольклора.

Ключевые слова: ономатопея, ономатоп, шутки и анекдоты, загадки, комический эффект

\section{Abstract}

the article deals with amusing cases of children's jokes and riddles containing imaginative onomatopoetic words. The jokes and riddles are playground fresh and were taken from a schoolkids' joke book that contains the jokes and riddles collected from schools in Britain.

Key words: onomatopoeia, onomatopoeic word, jokes and riddles, comic effect 
В данной статье рассмотрим занимательные случаи детских шуток, анекдотов и загадок, насыщенных звукоподражательными словами. Шутки и загадки заимствованы из сборника детского фольклора [3]. Они подслушаны или записаны на игровых площадках и школьных аудиториях. Анализируемые короткие юмористические тексты отражают детское словотворчество, способность к языковой игре и способность детей увидеть комичное в нашей жизни.

Ономатопея (греч. onomatopoeia - словотворчество, звукоподражание) определяется как «образование слов, условно воспроизводящих природные звуки, крики животных и т. д. (гав-гав, кукареку, мяу), а также создание слов путем звукоподражания (гавкать, кудахтать, куковать, мяукать)». [1, с. 243]. Во многих шутках и загадках комический эффект достигается именно за счет звукоподражания. Например,

- What goes peck bang, peck bang, peck bang, peck bang?

Ответ: a chicken in a mine field.

Ономатоп peck означает «клевать», «долбить клювом», а ономатоп bang «(шумно) хлопать», «грохотать», «шуметь».

\section{- What goes oink clink, oink clink, oink?}

Ответ: a piggy bank. Piggy bank - это копилка-свинка (детская, обычно в виде свиньи) [2, с. 331]. Piggy - детское слово, соответствующее русскому «поросенок», «свинка». Ономатопы, озвученные в загадке, передающие звуки, характерные для поросенка, и когда трясут копилку с монетами : oink (the characteristic grunting sound of a pig) - «хрюкать» и clink - «звенеть»; «звякать», «бряцать». Clink характеризует звон, отчётливый резкий звук, исходящий от маленьких звонких (металлических) предметов, например, ключей, монет.

\section{- What goes tick woof, tick woof, tick woof, tick woof?}

Ответ: $\boldsymbol{a}$ watch dog.

Watch dog или watchdog - это, прежде всего, сторожевой пёс (a fierce dog kept to guard property) [4, c. 1504]. Метафорически, watch dog - «наблюдательная комиссия» (а person or organization that tries to guard against stealing, wasteful use of public money, undesirable practices etc.) [4, c. 1504]. Наконец, это еще и «сторожевой таймер» или «контрольный таймер», аппаратно реализованная схема контроля над зависанием системы. Он представляет собой таймер, который периодически сбрасывается контролируемой системой. Последнее значение позволяет приписать сторожевому псу тиканье, передаваемое ономатопом tick. Ономатоп tick, таким образом, может передавать тиканье (например, часов): (of a clock or other mechanical device) make regular short, sharp sounds, typically one for every second of time that passes, а также может передавать жужжание, гудение.

Ономатоп woof передает гавканье, рычание (the barking sound made by a dog). Загадочный сторожевой пёс, таким образом, не только гавкает, но и тикает!

- A man went into a pet shop and said to the lady behind the counter, "Do you have any puppies going cheap?"

"No," said the lady, "they go woof. Our budgies go cheep."

В данном контексте go передает значение "make a sound of a specified kind" «издавать (какой-л) звук», как в “to go cluck" - кудахтать, “to go whirr" - зажужжать и под. Продавщица зоомагазина восприняла сочетание go cheap - «продаваться по дешёвой цене», «реализовываться дешево» как go cheep - «пищать». Языковая игра здесь построена на звуковом совпадении (омонимии) слов cheap (дешевый) и cheep писк (птенцов, мышей) - a shrill squeaky cry made by a bird, typically a young one. Поэтому попугайчики в зоомагазине «говорят» cheep а щенки «говорят» woof, хотя, как нам кажется, они должны тявкать, а не гавкать и рычать.

Таким образом, на примере нескольких детских шуток и загадок мы рассмотрели английские ономатопы, передающие звуки, издаваемые птицами, 
поросенком и собакой, а также ономатопы, передающие звуки механизмов. Они не совпадают с ономатопами русского языка, приписываемым рассмотренным животным, поскольку в каждом языке своя система звуков и особенное восприятие окружающего.

1. Розенталь Д. Э., Теленкова М. А. Словарь-справочник лингвистических терминов. Изд. 2-е, испр. и доп. - М.: Просвещение, 1976. - 543c.

2. Томахин Г. Д. Лингвострановедческий словарь Соединенное Королевство Великобритании и Северной Ирландии. - М.: АСТ-ПРЕСС КНИГА, 2003. - 720с.

3. Brough Girling. The Schoolkids' Joke Book. Collins, 1988. - 126p.

4. Longman Dictionary of English Language and Culture. New edition, 1998. - 1568p.

\section{Додукова Е.C. \\ Роль метафоры в социальной рекламе, посвященной пропаганде чтения}

Волгоградский государственный университет (Россия, Волгоград)

doi: $10.18411 / \mathrm{j}-08-2018-49$

idsp: 000001:lj-08-2018-49

\section{Аннотация}

В статье утверждается, что для продуктивного изучения специфики метафор в социальной рекламе необходимо рассматривать их отдельно по тематическим группам, поскольку в каждой группе используются свои образы. Так, в группе «Пропаганда чтения» особенно частотны метафорические модели «книга - дверь в неведомый мир и способ увидеть иную реальность», «человек сделан из книг, которые он читает», «заряжай мозги», «книга - пища для ума» и др.

Ключевые слова: социальная реклама, пропаганда чтения, метафора, воздействие в рекламе, рекламный образ.

Классическое определение метафоры истолковывает ее как троп или механизм речи, состоящий в употреблении слова, обозначающего некоторый класс предметов, явлений и т. п., для характеризации или наименования объекта, входящего в другой класс, либо наименования другого класса объектов, аналогично данному в каком-либо отношении [Арутюнова 1998, с. 296-297]. Метафора - эффективный инструмент воздействия, поэтому активно применяется во всех видах рекламы, в том числе и социальной рекламе (СР). Рекламная метафора дает возможность осмыслить одни объекты через свойства и качества других и направлена на повышение оригинальности рекламного текста.

На свойство метафор менять видение ситуации, подсказывать принятие решения, влиять на поведение давно обратили внимание исследователи - как психологи (Г.Ф. Черячукин, Е.Л. Доценко и т. д.), так и лингвисты (М.Р. Желтухина, О.С. Иссерс, А.П. Чудинов и др.) (см. об этом [Копнина 2010, с. 81]). Так, по словам американского философа Макса Блэка, метафора не только подмечает реальное сходство предметов, но и сама создает его, подсказывает новый взгляд на предмет, заставляет увидеть похожее в обычном [Теория 1990, с. 162-167].

Как правило, при исследовании метафоры оцениваются только словесные формы, однако специфика ее функционирования в рекламном дискурсе такова, что во многих случаях она создается на основе зрительного образа. В связи с этим учет визуальной составляющей представляется нам обязательным элементом анализа. Это тем более важно, что именно в изображении часто и сосредоточен воздействующий потенциал СР. Зрительный образ быстрее и проще проникает в сознание адресата и легче запоминается, 
поэтому на нем делается акцент, в то время как словесная часть либо вообще не используется, либо выполняет пояснительную и усилительную функции.

Во всех встретившихся нам работах метафоры в СР изучаются как единый массив, независимо от темы послания. Вместе с тем наблюдения показывают, что в разных тематических группах использование метафор имеет свою специфику, касающуюся как количества используемых образов, так и их содержания. Рассмотрение всего массива плакатов СР показывает, что больше всего метафор присутствует в группах «Охрана природы», «Борьба с вредными привычками» и «Пропаганда чтения». Напротив, крайне мало метафор в группах «Охрана животных», «Профилактика заболеваний» и «Помощь детям в детских домах» (О принципах выделения тематических групп в СР и их общем составе см.: [Анисимова 2017a; Анисимова 2017б]). Смысл же метафор полностью зависит от продвигаемых идей и существенно различается во всех группах.

В настоящей статье мы рассмотрим содержание метафор в группе «Пропаганда чтения». Для изучения этого вопроса нами было собрано 500 плакатов, посвященных пропаганде чтения, методом сплошной выборки из различных медиабанков сети Интернет, посвященных социальной рекламе. Оказалось, что метафоры содержит более четверти всех имеющихся здесь плакатов.

Как отмечает Ю.К. Редькина, «В процессе восприятия рекламного текста адресатом происходит введение объекта рекламы в систему представлений последнего об окружающем мире, и рекламируемый товар наделяется в этом плане новой ценностью» [Редькина 2014, с. 14]. Эта новая ценность нужна для того, чтобы сделать рекламируемый объект более привлекательным для адресата. Хотя СР не предназначена для продажи товара, однако идея использования ценностей адресата для того, чтобы сделать пропагандируемый тезис более привлекательным для него, характерна и здесь. Что же это за ценности?

На первом месте по частотности стоит модель, представляющая книгу как способ проникнуть в волшебный (необычный) мир, открывающий новые реальности $(8,5 \%$ от общего количества плакатов группы). Эта ценность связана с тем, что «в отличие от рекламы других товаров, которая может апеллировать к материальной пользе, выгоде, физическому удовольствию и другим ценностям человека, реклама книги всегда обращается только к интеллектуальным ценностям: к пользе духовного обогащения, интересу, интеллектуальному удовольствию» [Анисимова, Ярова 2011, с. 55]. Это же относится и к СР о пользе чтения: основная ее цель состоит в том, чтобы убедить адресата, что читать - это интересно. Для реализации этой идеи в данном случае используются две метафорические модели. Первая состоит в том, что сама книга предстает как дверь в неведомый мир. За этой дверью угадываются космические корабли, неведомые земли, сказочные персонажи и т.п. Эта модель составляет $2 / 3$ примеров в рассматриваемой группе. В остальных примерах книга так или иначе является инструментом, позволяющим читателю заглянуть в другую реальность. К этой модели относится и победитель конкурса «Читать не вредно, вредно не читать», проведенного издательством «ЭКСМО» в 2011 г. и изображающий мальчика, стоящего на высокой стопке книг, что позволяет ему заглянуть через брандмауэр из грязного двора в волшебный мир с феями и замками.

Вторая метафорическая модель наглядно реализует мысль: «Человек сделан из книг, которые он читает» (Р.У. Эмерсон). Идея о том, что внешний облик и восприятие человека окружающими во многом зависит от его начитанности, весьма популярна $(7,6 \%)$ и имеет несколько воплощений:

- Самая прямая реализация состоит в том, что фигура человека заполняется книгами или вообще человек складывается из книг. Если он читал много, вся фигура заполнена, если мало - она полупустая (Заполни пробель, $u$ тыл изменишься!). 
- Плакаты со слоганом Читай больше, будь человеком и Сотвори себя показывают, как субъект превращается из обезьяны в человека с помощью чтения книг.

- Твоя книга - твое лицо. Человек читает книгу, при этом ракурс такой, что лицо, изображенное на обложке, представляется нам лицом читающего и как бы отражает его мечты, интересы и тайные мысли.

— Человек вступает в контакт с другими людьми и становится видна его сущность: он рыба (баран) или яркий и умный (Чувствуешь себя рыбой? Потому что книги не читаешь).

Третья по частотности метафорическая модель реализует слоган Заряжай мозги (3,2\%). Эта идея может быть представлена несколькими способами: мозги заряжают с помощью батареек-книг; шнур от мозгов вставляют в книгу, как в электрическую розетку, или просто засыпают сверху в голову из книги кругозор, знания, мудрость и Т.П.

Следующая модель реализует слоган Книга - пищза для ума (3\%). Эта модель чаще всего представляется с помощью изображения книги в качестве еды: книга (или куча книг) на обеденной тарелке в окружении столовых приборов; книга как сосуд для напитка, из которого торчит соломинка для питья; человек отправляет в рот книгу (Hеm ничего вкуснее книги) и т.п.

Еще одна модель реализует слоган Будь на высоте (2,6\%). Эта модель показывает, что читающий человек стремится ввысь, парит над землей (у него вырастают крылья, и он летает). Чаще всего указанная метафора представляется с помощью изображения человека сидящего или стоящего на высокой стопке книг, что позволяет ему увидеть гораздо больше других людей; сопоставлении ребенка на стопке книг, с взрослым, стоящим на земле (Будь выще! Читай!), и т.П. Положение сверху (выше) должно подчеркивать преимущество, получаемое читающим субъектом над прочими. Это значение имеет универсальный характер, как показано в исследовании C.X. Битоковой, указывающей, что концепты Счастье, Радость в различных лингвокультурах мыслятся, в основном, как расположенные вверху, а Печаль преимущественно локализируется внизу [Битокова 2007, с. 63]. Продолжает этот образ изображение самих книг в виде птиц, стремящихся ввысь, что также должно символизировать стремление к счастью.

Остальные метафоры встречаются гораздо реже. Среди них отметим лишь модель, реализующую слоган Читай книги, прикройся $(1,2 \%)$, где книга изображается как часть облика читателя (одежда или прическа), и модель Книга - лекарство от глупости $(0,8 \%)$, где используются медицинские ассоциации.

Таким образом, дополнительное, сугубо рекламное содержание СР о пользе чтения, делающее чтение книг привлекательным для адресата, состоит в том, чтобы показать занимательность, полезность (не прагматическую, а сугубо интеллектуальную) чтения, способность сделать человека счастливее и наладить отношения с другими людьми. Метафора помогает привлечь внимание адресата и вызвать у него необходимые положительные эмоции, а также осмыслить одни объекты через свойства и качества других и повысить оригинальность рекламного текста.

$$
* * *
$$

1. Анисимова Т.В. Система ценностей государства в зеркале социальной рекламы (на материале социальной рекламы, посвященной проблемам семьи и воспитания) // Вопросы лингвистики, методики обучения языкам и литературоведения в свете современной науки: сб. научных трудов по млам I Международной научно-практической конференции. - СПб: Открытое знание, 2017а. - С. 5-11.

2. Анисимова Т.В. Тематический состав современной российской социальной рекламы (на материале плакатов, посвященных проблемам здоровья человека) // International Conference on Arts, Culture, 
Literature, Languages, Humanities and Philosophy for Sustainable Societal Development Conference Proceedings. - Rome, 20176. - C. 138-147.

3. Анисимова Т.В., Ярова И.В. Реклама в издательском деле: учебное пособие. - Ижевск: КнигоГрад, $2011-200 \mathrm{c}$.

4. Арутюнова Н.Д. Метафора // Языкознание. Большой энциклопедический словарь / под ред. В. Н. Ярцевой. - М., 1998.

5. Битокова С.Х. Концептуальная метафора и теория воплощенного реализма // Язык и межкультурная коммуникация: сб. ст. I Международной конференции (Астрахань, 23 января 2007 г.). - Астрахань: Астрах. ун-т, 2007. - С. 62-64

6. Копнина Г.А. Речевое манипулирование: учеб. пособие. - М.: ФЛИНТА: Наука, 2010. - 176 с.

7. Редькина Ю.К. Особенности выразительных средств автомобильной рекламы // От текста к печатному изданию: Проблемы филологического анализа и редакторской подготовки: М-лы III Регионального научно-практического семинара / науч. ред. О.А. Прохватилова. - Волгоград: ВолГУ, 2014.

8. Теория метафоры / пер. с анг., фр., нем., исп., польск. яз. / под общ. ред. Н.Д. Арутюновой, М.А. Журинской. - М.: Прогресс, 1990. - 512 с.

\section{Куксова Е.Л. \\ Роль и место французского языка во франкоязычной Африке \\ НИУ БелГУ \\ (Россия, Белгород)}

doi: $10.18411 / \mathrm{j}-08-2018-50$

idsp: 000001:lj-08-2018-50

\section{Аннотация}

В данной статье рассматривается языковая ситуация во франкоязычной Африке, роль и место французского языка и языков внутри- и межэнтнического общения. Отмечаются исторические предпосылки формирования франкофонии на африканском континенте и особенности текущей лингвистической ситуации.

Ключевые слова: франкофония, лингвокультурология, языковые контакты, билингвизм, французский язык.

\section{Annotation}

The article pays attention to the language situation in French-speaking Africa, to the role and the place of the French language and the languages of intra- and inter-ethnic communication. The article touches upon the question of the historical preconditions for the formation of Francophonie on the African continent and the features of the current linguistic situation.

Key words: francophony, linguoculturology, language contacts, bilingualism, French.

В современной лингвистике все чаще появляются исследования, посвященные языкам Африки. В свое время континент осваивали колонизаторские державы, которые оказали огромное влияние на текущую языковую ситуацию повсеместно в Африке. На сегодняшний день помимо автохтонных языков (языков аборигенов) на африканском континенте присутствуют английский, французский, испанский, португальский, арабский и др. языки. В настоящей работе рассмотрим вопросы становления французского языка и его роль и место во франкоязычной Африке.

Французский язык впервые появился в Африке в середине XVII века, когда французские колонизаторы вслед за португальцами стали организовывать морские экспедиции к берегам континента. В этот период Франция переживала переход от феодальных отношений к капиталистическим, сопровождающийся ростом промышленного производства, расширением торговых связей и повышением спроса на рабочую силу. Африканский континент открывал новые возможности для торговли, в том числе и торговле рабами, и промышленности.

Официально завоевание Африки французами началось в 1830 году на севере континента, в Алжире. Освоение новой территории и процесс превращения Алжира в 
колониальное владение Франции назвали «Алжирской экспедицией». Позднее Франция распространила свое влияние и на другие страны Северной и Северо-западной Африки, на территории так называемого Большого Магриба (Тунис, Марокко и Мавритания).

В начале 60-х годов XIX столетия Франция начинает завоевывать внутренние территории Африки. Успех французских завоевательных кампаний заканчивается в 1871 году после поражения в войне с Пруссией, вследствие чего метрополия на время приостанавливает колониальную агрессию.

Однако уже в конце 70-х годов Франция возобновляет колониальные действия, в результате которых в 1884-1885 гг. за Францией закрепляются владения в бассейне реки Конго, получившие название Французское Конго.

Колониальные войны продолжались с 1895 по 1904 гг., в результате чего образовалась Французская Западная Африка. В 1896 году Мадагаскар был объявлен колонией Франции. В 1910 году метрополия распространила свое влияние на Экваториальную Африку, сделав колониями Габон, Среднее Конго, Убанги-Шари и Чад. В это же время в 1908 году франкоязычная Бельгия завоевала часть Конго, которая получила название - Бельгийское Конго.

Ведение колонизаторской деятельности осложнялось ведением первой мировой войны, после которой африканские колонии в очередной раз были перераспределены между европейскими державами. Так, к бельгийской империи дополнительно отошла Руанда-Урунди, а к Франции - Того и часть Камеруна. К 1958 году французскими колониями также считались Сенегал, Мавритания, Французский Судан, Французская Гвинея, Берег Слоновой Кости, Верхняя Вольта, Дагомея и Нигер.

В результате активной колониальной деятельности Франции в Африке к концу XIX - началу XX вв. на ее территории была образована вторая по величине (после английской) французская колониальная империя. Последняя включала в себя обширные территории севера, запада и центра континента, а также остров Мадагаскар. Большая часть оккупированных государств получила статус колоний, но некоторые из них имели иной статус и именовались протекторатами. Особого статуса добился Алжир, став неотъемлемой частью Франции [Веденина 1988, с. 189].

Таким образом, распространение французского языка в Африке характеризуется: 1) насильственным подчинением целых стран и народов с их последующим включением в колониальные империи Франции и Бельгии, создание которых было завершено в конце XIX - начале XX вв.; 2), «офранцуживанием» или «францизацией» коренного населения нефранцузского происхождения, которое заключалось в закреплении французского языка в качестве официального, а также в навязывании населению этого языка, увеличении числа лиц, владеющих французским языком и знании французской терминологии.

Как отмечает Чередниченко, французский язык впервые распространялся в подобных социально-этнической и лингвокультурной среде, что не могло не предопределить ряд особенностей его дальнейшей эволюции. Более того, французский язык получил свое распространение на африканском континенте в то время, когда в самой метрополии уже был сформирован единый национальный литературный язык. Следовательно, народы стран Африки (в отличие от населения канадского Квебека и Акадии) обучались именно общенародному литературному языку, а не его диалектам. Основные «экспортеры» французского языка были чиновники колониальной администрации, военные, миссионеры [Чередниченко 1983, с. 18].

Таким образом, французский язык прочно вошел в жизнь африканцев через целенаправленное внедрение языка колониальной администрацией в различные сферы жизни завоеванных территорий.

Французский язык, несмотря на привилегированный статус, сосуществовал и до сих пор сосуществует в ситуации языкового многообразия среди более тысячи языков и различных диалектов. Африканский континент насчитывает от 1000 до 2000 языков. 
Такой разрыв в оценке количества языков в африканских странах, по мнению Н.М. Нгалассо, объясняется, во-первых, отсутствием учета «другого языка» (кроме официально признанных) при переписи населения, а, во-вторых, миграцией этносов и нечеткими критериями различия между африканскими языками и диалектами. В результате многие родственные языки при описании объединялись под одним названием и наоборот, диалекты одного языка, имеющие различные названия, выдавались за самостоятельные языки [Ngalasso 1986, с.11].

Местные языки Африки, согласно выполняемым функциям, можно разделить языки внутриэтнического и межэтнического общения.

Языки внутриэтнического общения соответствуют каждому этносу, который пользуется представленными языками для внутриэтнического взаимодействия, являясь средством коммуникации между членами этнической группы и фактором его этнокультурной принадлежности и этнолингвистической идентичности. Как правило, языки внутриэтнического общения являются родными языками, определяющими целостность этнической группы. Индивид, не владеющий языком, является чужаком.

Языки внутриэтнического общения привязаны к определенной территории, ее истории и традиционной культуре его носителей, являясь средством общения в кругу близких людей в устной неофициальной речи, они никогда не используются за пределами этнической группы в публичной области и не влияют на продвижение по социальной лестнице.

Языки межэтнического общения, наряду с французским и другими европейскими языками (английским, португальским и др.), являются средствами общения на региональном уровне. Африканцы, не владеющие европейскими языками, изъясняются на языках внутриэтнического общения в рамках своей этнической группы и на языках межэтнического общения с представителями других африканских народов.

Языки межэтнического общения играют важную социальную роль: являясь признаком образованности, языки межэтнического общения способствуют продвижению по социальной лестнице. Нередко языки межэтнического общения навязываются местному населению в ущерб языкам внутриэтнического общения.

Ж. Багана пишет, что в последнее время многие страны объявили межэтнические языки национальными и ведут политику, направленную на их развитие. Придание языкам межэтнического общения более высокого статуса может привести к закреплению за этими языками положения социально-политического превосходства. Основная функция языка межэтнического общения видится в том, «чтобы облегчить и упорядочить процесс коммуникации между членами разных этнических групп» [Багана 2004, с. 129].

Возвращаясь к французскому языку, отметим, что в Африке он представлен своим территориальным вариантом. Н.М. Фирсова отмечает, территориальный вариант языка обладает следующими характеристиками: 1) наличие официального (государственного) статуса; 2) отсутствие национальной литературной нормы; 3) наличие лингвокультурологической специфики. Более того, по мнению ученого, представленный вариант «не является родным для абсолютного числа жителей, а доля населения, говорящего на нем, составляет менее 50 \% общего числа населения страны, а также ему присуща известная» [Фирсова 2000, с. 20].

Так, французский язык в Африке не является родным для местного населения и не представляет собой основы для национально-этнической идентификации. Выполняя функции межэтнического и межгосударственного общения, а также языка образования, науки, современного производства и средств массовой информации, французская речь, тем не менее, не является национальной и используется лишь отдельными слоями общества.

Однако французский язык выполняет особую роль на континенте, являясь единственным этнически нейтральным языком, он объединяет многочисленные группы 
местного населения, что делает французский язык единственным языком, выполняющим межэтническую функцию в полном объеме.

В последние годы, согласно В.Т. Клокову, местный вариант французского языка воспринимается как «часть собственной африканской культуры, складывающуюся языковую традицию которой франкоязычные африканцы считают своим долгом поддерживать» [Клоков 2000, с. 20].

Французский язык прочно вошел в лингвокультурную жизнь африканских народов и является средством выражения мыслей и чувств африканцев. Африканцы перестали считаться простыми потребителями французского языка, они сумели преобразовать некогда чужеземную речь, сделав ее пригодной для выражения своих мыслей и культурных ценностей.

Подводя итоги, обратим внимание на то, что колонизация оказала значительное влияние на лингвокультурную традицию африканцев так, что даже получение этими странами независимости не повлияло на функциональную нагруженность и социальное положение языков в странах Африки.

Рассмотренная нами лингвистическая ситуация в странах Африки свидетельствует о существовании билингвизма и плюрилингвизма, обусловленном историческим навязыванием языков и культур колонизаторов, а также этнолингвистическим многообразием самих африканцев. Франкоязычная Африка характеризуется, с одной стороны, противопоставлением французского языка и языкам межэтнического общения и, с другой стороны, противопоставлением языков межэтнического и внутриэтнического общения. При этом французский язык занимает верхнюю ступень в языковой иерархии, затем следуют языки межэтнического общения и на нижней ступени находятся языки внутриэтнического общения. Каждый из языков закреплен за определенной территорией и выполняет отведенные ему функции, представляющие собой ценность в отношении взаимодополняемости языков.

$$
* * *
$$

1. Багана Ж. Языковая интерференция в условиях франко-конголезского билингвизма: дис. ... д-ра филол. наук. Саратов, 2004. 350 c.

2. Веденина Л.Г. Особенности французского языка: Пособие для учителя. М.: Изд-во Просвещение, 1988. $280 \mathrm{c}$.

3. Клоков В.Т. Французский язык в Африке. Лингвокультурологическое исследование. Саратов: Изд-во Сарат. ун-та, 2000. 284 с.

4. Фирсова Н.М. Языковая вариативность и национально-культурная специфика речевого общения в испанском языке. М.: Изд-во РУДН, 2000. 127c.

5. Чередниченко А.И. Язык и общество в развивающихся странах Африки. Киев: Изд-во при Киев. ун-те, 1983. $165 \mathrm{c}$.

6. Ngalasso M.M. Etats des langues et langues de l'Etat au Zaïre // Politique africaine. Paris: Karthala, 1986. № 23. P. 6-27. 


\section{JUURNAL.RU}

Научный журнал

Тенденции науки и образования в современном мире

№41, 08.2018

Август 2018 г.

Часть 2

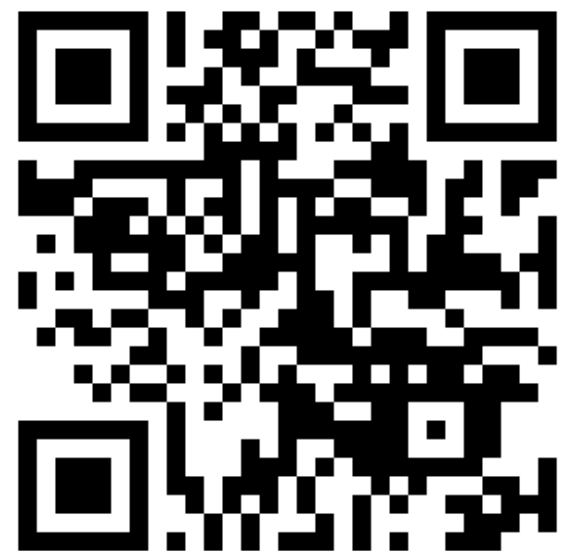

SPLN 001-000001-0329-LJ

Подписано в печать 12.09.2018. Тираж 400 экз.

Формат.60х841/16. Объем уч.-изд. л. 4,83

Бумага офсетная. Печать оперативная.

Отпечатано в типографии НИЦ «Л-Журнал»

Главный редактор: Иванов Владислав Вячеславович 